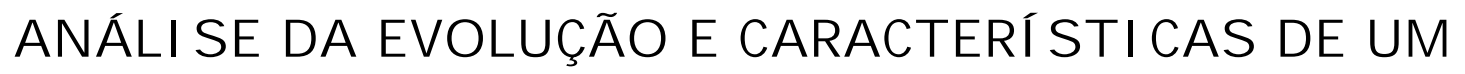
$S$ ERVI ÇO DE ANATO MI A PATO LÓ GICA BUCAL DURANTE O PERÍ ODO DE 37 ANOS

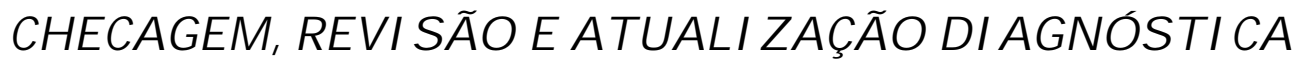

Tânia Regina Grão Velloso

Dissertação apresentada à Faculdade de Odontologia de Bauru da Universidade de $S$ ão Paulo, como parte dos requisitos para a obtenção do título de Mestre em Odontologia, área de Patologia Bucal.

(Edição Revisada)

Bauru

2001 
ANÁLIS E DA EVO LUÇ ̃̃O E CARACTERÍS TICAS DE UM $S \mathcal{E R V I C ̧ O ~} \mathcal{D E} \mathcal{A N} \mathcal{N} \mathcal{T} O \mathcal{M} I \mathcal{A}$ PATO LÓ GI CA BUCAL DURANTE O PERÍ ODO DE 37 ANOS

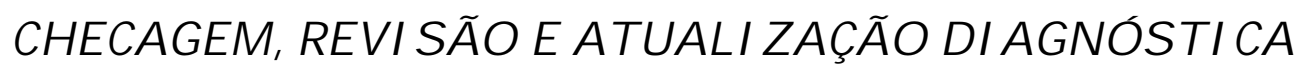

Tânia Regina Grão Velloso

Dissertação apresentada à
Faculdade de Odontologia
de Bauru da Universidade
de São Paulo, como parte
dos requisitos para a
obtenção do titulo de
Mestre em Odontologia,
áreade Patologia Bucal.

(Edição Revisada)

Orientador

Prof. Dr. Alberto Consolaro

Bauru

2001 
Foto da capa: Microscópio Zeiss no 17490, fabricado no final do século XIX, pertencente ao Optische Museum Oberkochen. Fotografado por Alfons Glocker e Klaus Werner, Carl Zeiss Oberkochen.

Velloso, Tânia Regina Grão

V546a Análise da evolução e características de um Serviço de Anatomia Patológica Bucal durante o período de 37 anos: checagem, revisão e atualização diagnóstica / Tânia Regina Grão Velloso - - Bauru, 2001.

119 p. : il. ; $28 \mathrm{~cm}$.

Dissertação. (Mestrado) - - Faculdade de Odontologia de Bauru. USP.

Autorizo, exclusivamente para fins acadêmicos e científicos, a reprodução total ou parcial desta dissertação/tese, por processos fotocopiadores e outros meios eletrônicos.

Assinatura:

Bauru, 03 de outubro de 2001. 
Tânia Regina Grão Velloso

18 de fevereiro de 1960

Filiação

$1978 \cdot 1981$

$1981-1982$

$1997 \cdot 1998$

1999

2000

$1999 \cdot 2001$
$\mathcal{N a s c i m e}$ nto

I ayme de Gouvêa Mendonça Velloso gacy Grão Velloso

Curso de Graduação em Odontologia pela Universidade Federal do Rio de I ane iro

Curso de Especialização e m Patologia Buc al pe la UFRJ

Professora em Patologia Bucal, na Faculdade de Odontologia da UFES

Professora em Patologia Geral e Bucal da Faculdade de Odontologia da Universidade Paulista em Bauru, S ão Paulo

Professora em Patologia Geral, na Faculdade de Odontologia da Universidade Metodista de Piracicaba em Lins, $S$ ão Paulo

Mestrado em Odontologia, área de Patologia Bucal, na Faculdade de Odontologia de Bauru, USP 
Sob a lente de um microscópio, até mesmo uma particulazinfa de nada, a sombra de um cisco, pode parecer um céu cheio de estrelas. Da mesma maneira, sob o olhar de uma verdadeira psicologia, o mais leve movimento da alma, por menor que seja, ou mais tolo, ou louco, ou perigoso, pode transformar-se na mais excitante cena. Ai veremos então a mais intrigante imagem da coisa mais sagrada que confecemos - a vida!

$\mathcal{H e}$ rmann $\mathcal{H e}$ sse 
Dedico este trabalho,

Ao meu pai (in me moriam) e minfa mãe,

por me ensinarem a sonfiar.

Ao me u marido e filfos,

por juntos irmos em buscados sonfos.

Ao meu mestre, orientador e amigo, por permitir sua realização. 


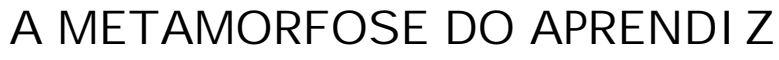

Alberto Consolaro

Os momentos passados ...

Ah! verdadeiros diamantes da vida!

E eu? ... que só confecia os brilhantes !

Eque falsos, por is so brilfantes!

Mas agora conheço diamantes ...

As pessoas compartilhadas ...

Ah! verdadeiros professores da vida!

E eu? ... que só contecia os aprendizes!

Eque imaturos, por isso aprendizes!

Mas agora confeço vocês: professores...

Desafio maior do que a ciência é saber expressar nossos sentimentos e amar plenamente, num doar sem fim. Ao meu orientador, meu carinfo e admiração. 


\section{Agradecimentos pessoais}

Temendo pecar por omissões imperdoáveis, quero agradecer especialmente à/aos:

Professores da Disciplina de Patologia Luis Taveira, Denise, Vanessa pela disponibilidade e atenção.

Funcionários da Patologia Cristina, Bernadete, Valdir, Fátima por fazer da Patologia uma extensão de nossa casa.

Bibliotecária Cybele, pela revisão do trabalho, paciência, e incentivo.

De mais funcionários da Biblioteca, pela atenção, carinho e profissionalismo.

Álica Carolina pela contribuição decisiva na elaboração do abstract e participação nas diversas etapas do desenvolvimento deste trabalho com a mesma empolgação do início.

Aline e Tarcília pela cumplicidade, amizade e senso de compromisso.

Telma e Paulo sempre presentes nos momentos mais críticos, dando a tranqüilidade e o apoio necessários ao término do curso.

Laurindo por participar efetivamente em meu crescimento profissional. 
Meus colegas do curso de pós-graduação em Patologia Bucal, Rosário, Simone, Valdomiro, Sandra, Lídia, I ussara, Braz, Mírian, Eloi e Daniel pela partilha e ensinamentos da convivência e m grupo.

Aos meus irmãos, em especial minha irmã Márcia, pela 6ondade, firmeza das decisões tomadas e apoio mes mo à distância.

Minha sogra Vanda pelo incentivo, entusiasmo e solicitude.

Meus amigos da UFES, Ivette, Francisco, Ricardo, Rosa, Roseane, Carlos Roldi, Hudson, Dr. Ioão, Fátima, Marly, Armelindo, Ioão Batista, Teresa, Maria Helena, Alfredo, Denise, Iosé We ber, Liliana, Padilha, Ioão Helvécio, Adaulto, Anra, Dilson pelo apoio incentivo e confiança.

Claudia e Maria Fernanda, mesmo pertencendo a outro curso, sempre transmitindo confiança e amizade.

O que nosso cérebro pensa e diz não passa de uma ninharia, comparado com o que, sob o impacto das "paixões", ocorre e se manifesta em nossa vida, em nossas relações e amizades.

Hermann Hesse 
Agradecimentos Ins titucionais

Ao Departamento de Estomatologia, da Faculdade de Odontologia de Bauru, Universidade de São Paulo.

À Direção da Faculdade de Odontologia de Bauru, Universidade de São Paulo, na pessoa do Diretor Prof. Dr. Aymar Pavarini.

À Comissão de Pós-Graduação da Faculdade de Odontologia de Bauru, Universidade de São Paulo, na pessoa do Presidente, Professor Doutor Luís Fe rnando Pegoraro.

À Biblioteca da Faculdade de Odontologia de Bauru.

À Re prografia da Faculdade de Odontologia de Bauru.

À CAPES pelo auxílio pecuniário. 


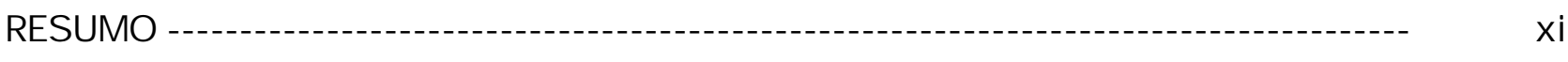

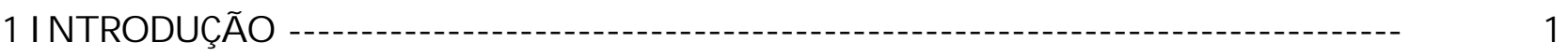

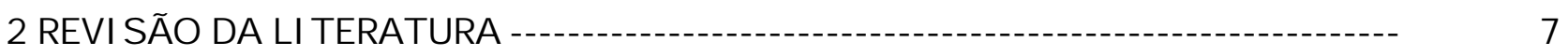

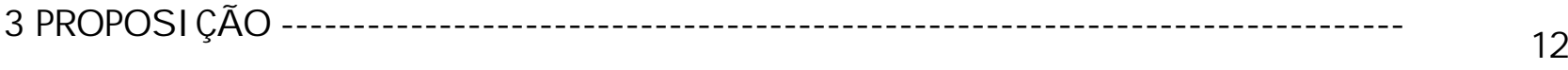

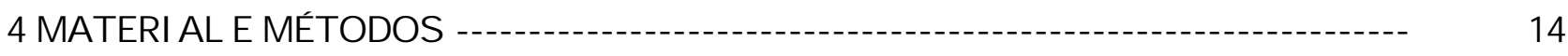

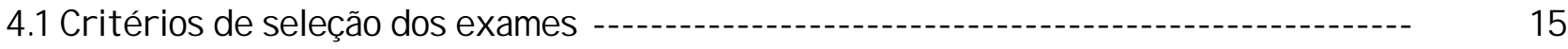

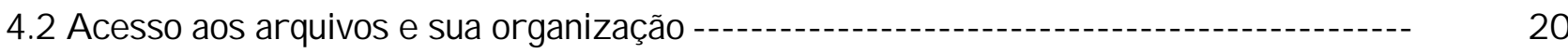

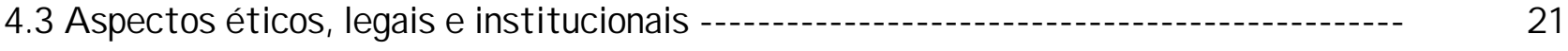

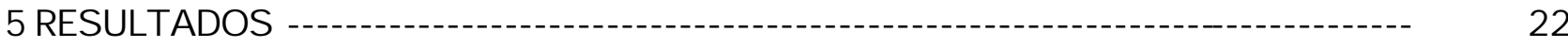

5.1 Da espécie de origem do mate rial coletado a cada ano de atividade .............. 24

$5.2 \mathrm{Da}$ origem e tipo do mate rial e m re lação à boc a cole tado a cada ano de atividade .... 25

5.3 Do resgate das provas documentais e/ou material dos diagnósticos efetuados a cada

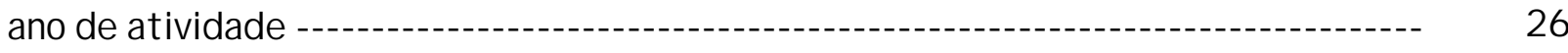

5.4 Do material enviado para análise e m relação à qualidade/ quantidade a cada ano de

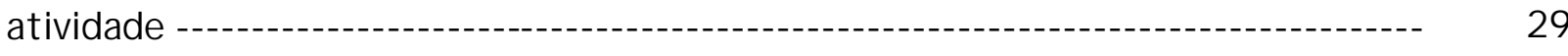

5.5 Da forma de apresentação dos diagnósticos efetuados a cada ano de atividade ..... 30

$5.6 \mathcal{D a}$ condizibilidade diagnós tic a com a nomenclatura atual a cada ano de atividade .... 31

5.7 Dos diagnósticos revistos quanto a condizibilidade com a nomenclatura atual de todos

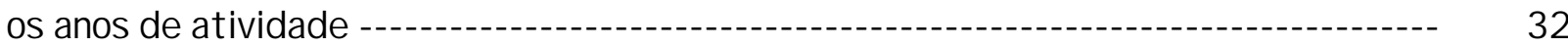

5.8 Dos diagnósticos efetuados de acordo com sua checagem frente ao confecimento

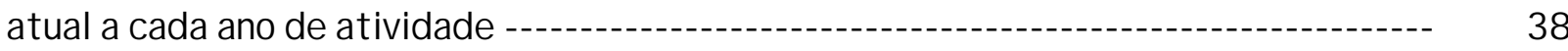

5.9 Dos diagnósticos revistos e a natureza das lesões de todos os anos de atividade ..... 39

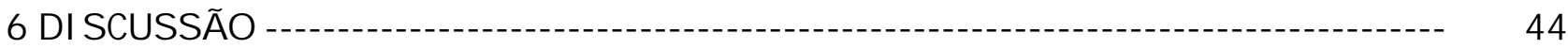

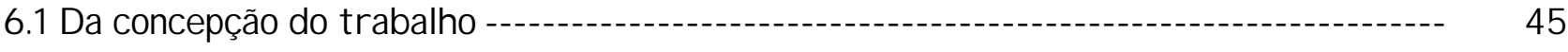

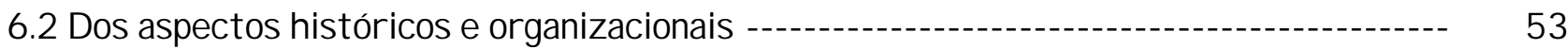

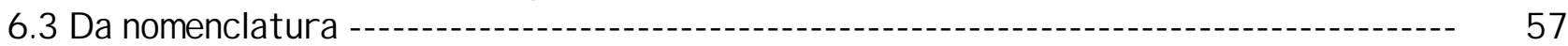

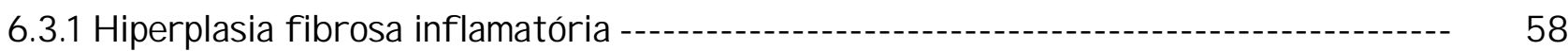

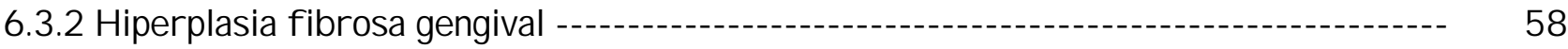

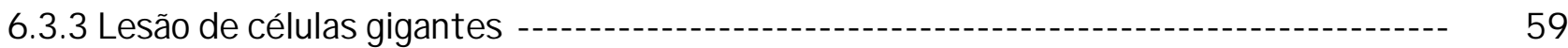

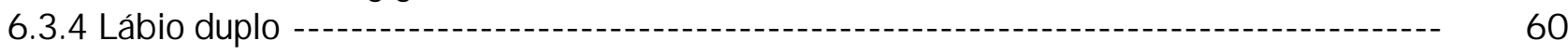

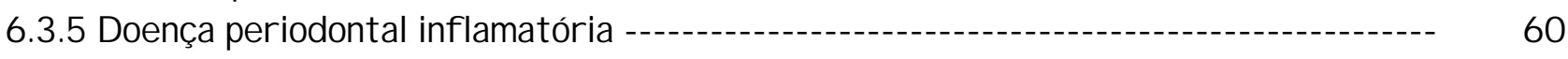




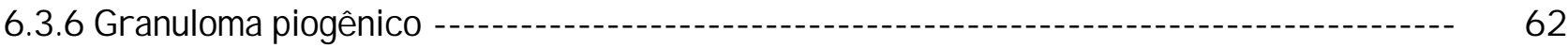

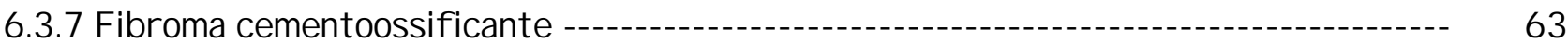

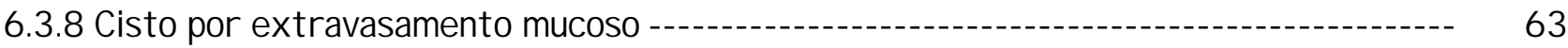

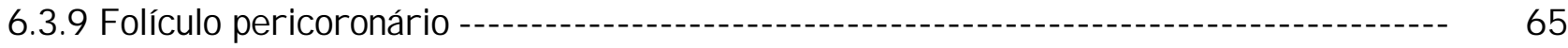

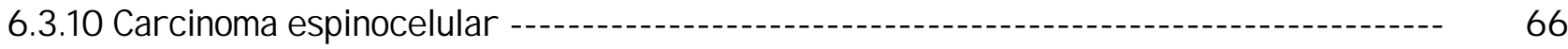

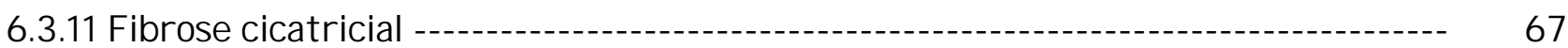

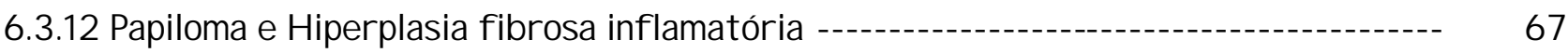

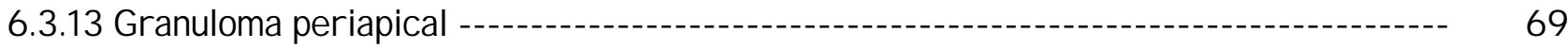

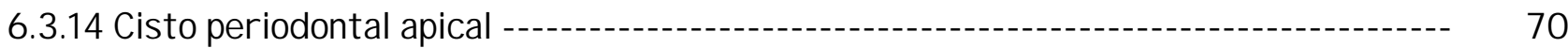

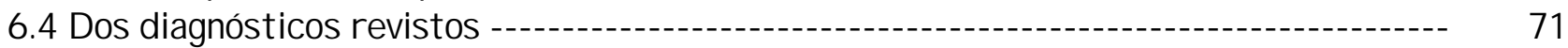

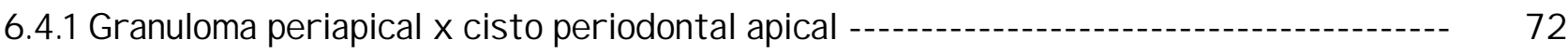

6.4.2 Cis to residual $\chi$ ame loblastoma unicístico $\chi$ queratocisto odontogênic o $\chi$ cis to

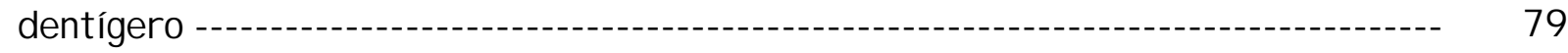

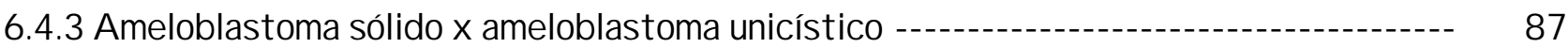

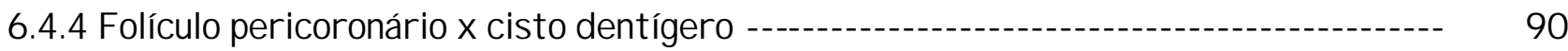

6.4.5 Carcinoma odontogênico de células claras x Carcinoma espinocelular $\chi \quad 91$

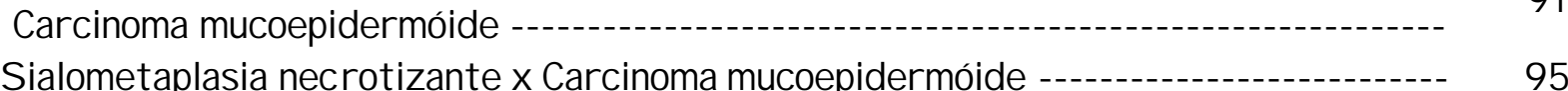

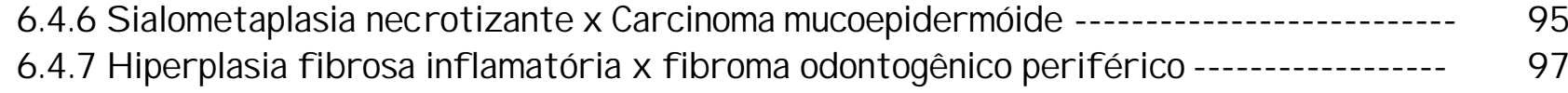

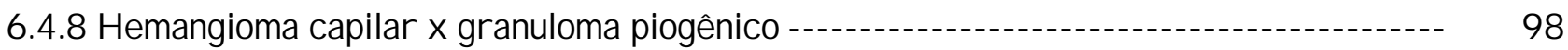

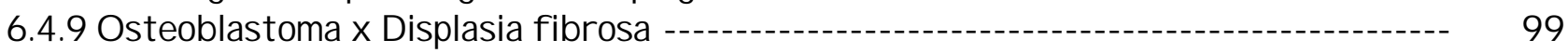

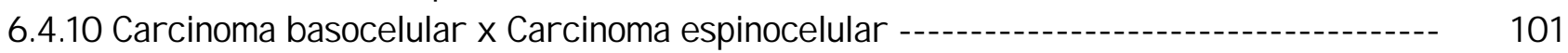

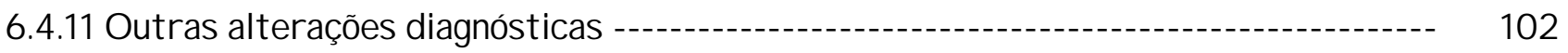

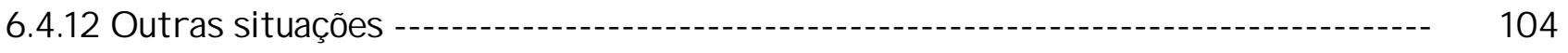

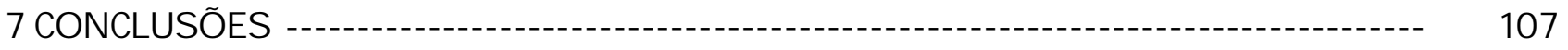

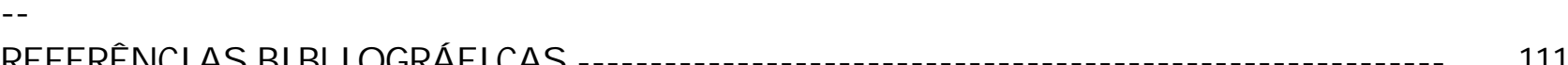

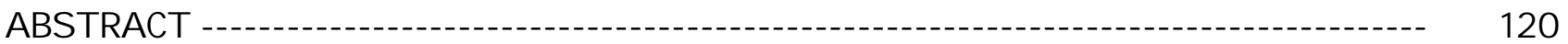




\section{RES UMO}

Análise dos arquivos do Serviço de Anatomia Patológica da Faculdade de Odontologia de Bauru, Universidade de São Paulo, desde 1963 a 2000; para estudar sua evolução e características, promovendose uma revisão e atualização dos seus arquivos e métodos. Observou-se um aumento crescente e significativo da demanda dos serviços prestados, bem como um aperfeiçoamento destes. Realizou-se uma revisão de laudos, blocos e lâminas, avaliando-se a nomenclatura das lesões se condizente com a atual; o recontecimento de entidades clínic as novas e os erros de diagnóstico. Discutiu-se as prováve is razões para as diferenças encontradas e concluiu-se da necessidade de atualização constante no trabalho em grupo, bem como do estimulo constante à análise crítica dos conceitos e critérios diagnósticos em todos os momentos da prática da patologia bucal como especialidade odontológica. 
$1 I \mathcal{N} \mathcal{T} R O D \mathcal{D C C} \tilde{A} O$ 


\section{$1 \quad$ I $\mathcal{N} \mathcal{T} O \mathcal{D U C ̧ \tilde { A } O}$}

$\mathcal{A}$ Patologia Bucal deixou de ser uma simples matéria curricular, ou mero crédito a ser cumprido, para constituir-se parte integrante e essencial na formação do cirurgião-dentista. Também como especialidade, ela vem cravando suas estacas com firmeza, não só devido às imposições de uma sociedade mais esclarecida, como também da própria conscientização profissional, embora de forma paulatina mas crescente. Todos os tecidos removidos do corpo fumano devem ser submetidos à análise microscópica ${ }^{9}$. Algumas alterações, consideradas inicialmente como variações do normal, podem representar manifestações precoces de uma les ão maligna, ou ainda manifestações primárias de uma condição sistêmica.

O ciclo ou processo diagnóstico do Serviço de Anatomia Patológica se inicia com o registro da peça cirúrgica enviada, de vendo conter todos os dados relacionados ao paciente, como nome completo, endereço, nacionalidade, estado civil, data do nascimento, vícios, fábitos, inclusive com um breve resumo clínico da lesão. Esses dados devem ser meticulosamente conferidos, evitando possiveis erros. $\mathcal{A}$ organização permite uma dinâmica maior e mais eficaz do Serviço. Todos os membros participantes do processo precisam estar em 
perfeita consonância, como em uma ópera, onde qualquer acorde errado compromete a essência da obra.

Após registrado, o espécime passará por diversos procedimentos no laboratório, como a macroscopia, processamento tecidual e preparo dos cortes teciduais em lâminas de vidro para posterior análise microscópica. O término desse ciclo somente se dará na entrega do diagnóstico ao profissional que o enviou e arquivamento do material gerado. A confiabilidade diagnóstica e o tempo do ciclo determinarão a eficácia do serviço.

Os especialistas em Patologia Bucal têm comparativamente um número reduzido, bem como os serviços de Anatomia Patológica Bucal. Em geral, observam-se laboratórios privados de Anatomia Patológica coordenados por especialistas em Patologia Geral. As Faculdades de Odontologia são muitas, mas apenas algumas oferecem Serviço de Anatomia Patológica. Poucas possuem instalações adequadas e profissionais qualificados à implantação de um laboratório. Tal fato é compreensível diante da falta de "tradição" no envio de espécimes 6ucais para processamento por parte do cirurgião-dentista.

Um dado intrigante e ao mesmo tempo reflexo de uma situação ainda atual é a ausência de uma Sociedade Brasileira de Patologia Bucal e a falta de cursos de especialização em Patologia Bucal. A boca, fica 
delegada como um apêndice do corpo fumano, quando deveria ser valorizada como parte integrante de todo um sistema. Quantas surpresas ou mesmo decepções poderiam ser evitadas com a prática do envio de peças cirúrgicas bucais para o diagnóstico microscópico final. Cabe ao cirurgião-dentista de qualquer especialidade, o diagnóstico precoce de doenças bucais e seu tratamento, esta responsabilidade envolve não só a vida, mas tam bém a qualidade de vida.

O Serviço de Anatomia Patológica Bucal da $\mathcal{F O B} / \mathcal{U} S \mathcal{P}$ teve seu início em 1963. Desde então, aumenta sua demanda quantitativa e qualitativa. A interface se faz com várias faculdades, profissionais em suas clinicas e consultórios, como também com patologistas através de laudos de consultoria. Essa realidade trouxe a necessidade de informatização do serviço com a implantação de programas específicos, além da substituição de processamentos manuais por mecânicos.

A cada década a informação e o contecimento se renovam mais rapidamente; os avanços tecnológicos facilitam as pesquisas, geram novas inquie tações; possibilitam a 6 usca constante pelo confecimento.

A nomenclatura das lesões, a terminologia utilizada, os métodos para sua análise e os critérios de diagnósticos evoluem e modificam-se. Entidades clínicas passam a ser reconfecidas. Algumas são abolidas após o avanço do confecimento e indicadas como variável de um outro 
processo patológico, ou ainda como fase de uma determinada doença já descrita. O diagnóstico correto em toda sua plenitude se faz essencial para um planejamento terapêutico adequado e prognóstico favorável.

Há algumas décadas, não se fazia diagnós tico de:

- Queratocisto odontogênico, mas sim de cistos epidermóides, cistos residuais e outros cistos com me taplasia escamosa;

- Ameloblastoma unicístico, mas sim de transformação ame loblastomatosa em cistos odontogênicos;

- Displasia cementoóssea florida, mas sim de osteomielite crônica esclerosante supurativa ou não.

Há algumas poucas décadas, ainda se diagnosticava:

- Cis to globulomaxilar

- Cis to mandibular mediano

- Cisto palatino mediano

Algumas lesões foram identificadas à parte e hoje são diagnostic adas como:

- Cis to odontogênico glandular

- Cisto odontogênico botrióide

- Tumor odontogênico escamoso 
- Tumor dentinogênico de células fantasmas

- Carcinoma odontogênico de células claras

As instituições devem se preocupar não só na reciclagem dos seus profissionais, mas também na atualização de seus dados, de seus arquivos. Estes são referências para estudos, teses, monografias e dissertações. Um arquivo estático reflete o abandono, a estagnação diante da vida. A revisão temporária do acervo de um Serviço de Anatomia Patológica Bucal gera questionamentos científicos, possibilita uma reflexão de sua dinâmica e do grau de envolvimento e cumplicidade de seus membros. Critérios estabelecidos para o diagnóstico das lesões, devem ser revistos, discutidos e embasados na literatura atualizada. Se assim for, o acervo da Instituição será impar e passível de ser explorado constantemente. 


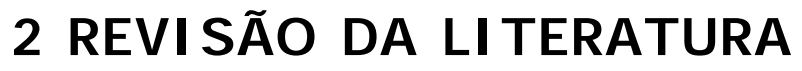




\section{REVIS $\tilde{A} O \mathcal{D A} L I \mathcal{T E R} \mathcal{T} U R \mathcal{A}$}

$\mathcal{A}$ preocupação quanto à otimização dos Serviços de Anatomia Patológica Bucal a partir da sua análise técnica e fistórica, procurando avaliar sua evolução ao longo do tempo, assim gerando fundamentos para estabelecimento de novos objetivos e mecanismos de checagem de sua estrutura organizacional, também deve acontecer em outras Instituições, mas a publicação mostra-se restrita.

$\mathcal{N a}$ literatura pertinente resgataram-se seis trabalhos a serem analisados. Nãa foram incluídos os trabalhos referentes às lesões com diagnósticos revistos e ou com a nomenclatura não condizente. Esses foram citados na discussão para embasar os critérios diagnósticos adotados na rotina do Serviço de Anatomia Patológica. A referência a estes trabalhos clássicos se fez no capitulo de discussão e de referências bibliográficas.

$\mathcal{N a}$ análise de 20 anos do Serviço de Anatomia Patológica do Departamento de Patologia Bucal do Birmighan Dental Hospital, WILLIANS; HEY; BROWN $\mathcal{E}^{56}$ utilizaram como base os dados referentes aos anos de 1975,1984 e 1994. Verificaram os diagnósticos mais freqüentes, e os que apresentavam maior indice de erro quanto ao 
diagnós tico clínico. Também avaliaram a quantidade e qualidade dos espécimes recebidos separando-os em duas categorias: tecido mole e tecido duro, neste último incluindo lesões intra-ósseas e dentes. Ainda classificaram a natureza do espécime, se tecido mole ou tecido duro. Concluiram que o aumento do número de espécimes enviados para exame nesse perído, refletia uma maior conscientização dos clínicos gerais da necessidade de confirmação microscópica ou esclarecimento das diversas alterações dos tecidos bucais.

MCBROOM; RAMSAY $\mathcal{Y}^{32}$ avaliaram os encontros clínicos patológicos em Southanpton University Hospital, para discussão de diagnósticos microscópicos. Classificaram-nos em não alterados, refinados e alterados quando errados. Também observaram as implicações desta alteração no tratamento, classificando-as como: sem efeito, de efeito menor e tratamento totalmente mudado. Puderam inferir da importância dessas reuniões a identificação de problemas diagnósticos específicos gerando maiores informações, além de aumentar a interação entre clínico e patologista.

O tempo decorrido entre o recebimento de um espécime para análise microscópica pelo Laboratório de Anatomia Patológica do Departamento de Patologia Bucal, Medicina Oral e Periodontia, Faculdade de Odontologia, University de Malayade, até a entrega do 
diagnóstico ao profissional requisitante foi avaliado por $S I \mathcal{A R}: \mathcal{T A} \mathcal{N}^{46}$. Utilizando-se desse tempo avaliaram a eficácia do Serviço, bem como fizeram um estudo da performance de cada patologista envolvido no processo. Quanto menor o tempo mais eficaz. Consideraram ser excelente o tempo de dois dias, satisfatório de cinco a sete dias, insatisfatório de 15 a 30 dias e não aceitável com mais de 60 dias. Concluiram ser dois dias o tempo ideal desse ciclo, para isso sendo necessário a educação, motivação, rígida supervisão da máquina operacional e o uso de meios mais eficazes na entrega dos resultados como o correio ele trônico.

ORGANi $\mathcal{M A I N}^{36}$ analisaram a clientela e a demanda do Serviço de Anatomia Patológica Bucal da Faculdade de Odontologia da Universidade de Toronto no período de oito meses, novembro de 1974 a junho de 1975. Observaram ser os dentistas clínicos gerais os que mais enviavam espécimes para análise, embora representando $91 \%$ dos dentistas o número de espécimes enviados ainda foi baixo. Atribuíram o pouco envio de espécime por clínicos gerais, ao encaminfamento dos pacientes para especialistas, principalmente cirurgião bucomaxilofacial, bem como ao envio para o Hospital de Ontário, onde também funciona a anatomopatologia. 
Através de dados obtidos dos arquivos virtuais do Departamento de Patologia e Laboratório Médico da University of South Carolina como nome, nascimento, origem do espécime, relato clínico, número de registro e outros, $S \mathcal{M I} \mathcal{T H} ; G \mathcal{A R V I} \mathcal{N}^{48}$ avaliaram o tempo entre o recebimento do espécime e a entrega do diagnóstico ao clínico remetente. De acordo com a Association of Directors of Anatomic and Surgical Pathology o ideal seria de dois a três dias. Quando o espécime necessitar de técnicas especiais de processamento, este tempo aumentaria. Os autores concluíram ser importante esta avaliação para paciente, patologistas, clinicos e administradores.

$\mathcal{A}$ importância do exame microscópico de espécimes bucais como

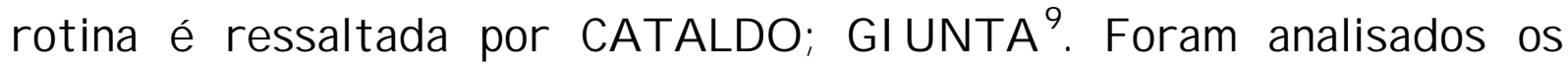
cortes microscópicos de 2005 espécimes bucais do Serviço de Diagnóstico do Departamento de Patologia Bucal, Tufts University School of Dental medicine. Dentes, tecidos provenientes de gengivectomia, citologia esfoliativa e cortes microscópicos de consultoria foram excluídos da amostra. As lesões foram classificadas quanto a sua natureza. Também avaliaram a freqüência de ocorrência das lesões, destacando a responsabilidade do cirurgião-dentista no diagnóstico precoce do câncer bucal. 


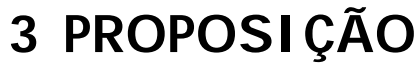


3 PROPOS IC ̃̃O

$\mathcal{A}$ partir dos arquivos de documentos, de cortes teciduais em lâminas de vidro, de blocos de inclusão em parafina e dos livros de registros e de laudos emitidos do Serviço de Anatomia Patológica Bucal da $\mathcal{F O B}$ - US P propôs -se a:

1. analisar as características evolutivas temporais da casuística do referido Serviço nos últimos 37 anos;

2. rever ou confirmar os diagnósticos e mitidos quanto a condizibilidade da nomenclatura com o confecimento atual;

3. checar os diagnósticos emitidos quanto a sua condizibilidade com o confecimento atual, revendo ou confirmando-os;

4. discutir as prováveis razões para as diferenças encontradas quanto a condizibilidade da nomenclatura e dos diagnósticos anteriomente emitidos. 
$4 \mathscr{M A T E R I \mathcal { A L }} \mathcal{E} \mathcal{M E ́} \mathcal{T} O D O S$ 


\section{$4 \mathcal{M A T E R I} \mathcal{A L} \mathcal{E} \mathcal{M E ́} \mathcal{T} O \mathcal{D O S}$}

4.1 Critérios de seleção dos exames para obtenção da amostra

Os exames passive is de reanálise diagnóstica foram classificados e selecionados dos arquivos do Serviço de Anatomia Patológica Bucal da $\mathcal{F O B}$ - US P a partir dos critérios a serem descritos.

a. De acordo com a espécie de origem do material coletado a cada ano de atividade do Serviço de Anatomia Patológic a da FOB/USP

Dos arquivos de laudos emitidos foram selecionados os casos pertencentes a seres fumanos e descartados da análise os de seres animais irracionais. Os dados foram dispostos em figuras como no mode lo abaixo:

\begin{tabular}{|c|c|c|c|c|c|c|c|c|c|c|c|} 
Ano & Ano & Ano & Ano & Ano & Ano & Ano & Ano & Ano & Ano & Ano & Ano \\
\hline Humano & & & & & & & & & & & \\
\hline Animal & & & & & & & & & & & \\
\hline
\end{tabular}

6. Classificação dos diagnósticos efetuados de acordo com a origem e tipo do material em relação à boca, coletado a cada ano do Serviço de Anatomia Patológic a Buc al da FOB $/ \mathcal{H}$ P

Do livro de registros dos espécimes, foram selecionados os casos correspondentes às peças cirúrgicas exclusivamente constituídas por 
tecidos bucais e peribucais humanos, entendendo-se como peribucais, os tecidos do terço médio e inferior da face.

Os tecidos moles e duros independentemente de sua origem embriológica, odontogênica ou não, foram incluídos na amostra. Também foi determinada a quantidade de casos de localização não bucais e de esfregaços. Os dados coletados foram dispostos em figuras, como no mode lo abaixo:

\begin{tabular}{|c|c|c|c|c|c|c|c|c|c|c|c|}
\hline Ano & Ano & Ano & Ano & Ano & Ano & Ano & Ano & Ano & Ano & Ano & Ano \\
\hline Bucal & & & & & & & & & & & \\
\hline Não bucal & & & & & & & & & & & \\
\hline Esfregaço & & & & & & & & & & &
\end{tabular}

c. Classificação dos diagnósticos efetuados quanto ao resgate das suas provas documentais e/ou material a cada ano de atividade do Serviço de Anatomia Patológic a Bucal da FOB $/$ ULS $P$

$\mathcal{A}$ partir dos livros de registros, livros de laudos, arquivos de lâminas e arquivos de blocos foram revistos todos os casos e checados quanto a documentação presente. Os cortes microscópicos precisavam apresentar coloração preservada, as laminulas e lâminas sem fraturas ou bolhas, assim como não deviam conter artefatos de técnica que inviabilizassem análise criteriosa. Quando da necessidade de confecção 
de novos cortes, os blocos de parafina correspondentes deviam apresentar a superfície de corte preservada e livre de qualquer tipo de contaminação ou dano, além de possuir material suficie nte para novos cortes.

Após o resgate, avaliação e reposição, quando possível, da documentação, os dados obtidos foram dispostos em figuras como no mode lo ab aixo:

\begin{tabular}{|c|c|c|c|c|c|c|c|c|c|}
\hline S ituação / Ano & $\mathcal{A n o}$ & Ano & Ano & Ano & $\mathcal{A n o}$ & Ano & Ano $\quad$ Ano & Ano & Ano \\
\hline $\begin{array}{c}\text { Com registro, laudo, } \\
\text { Câmina e bloco }\end{array}$ & & & & & & & & & \\
\hline $\begin{array}{c}\text { Com registro, laudo, lâmina } \\
\text { e sem bloco }\end{array}$ & & & & & & & & & \\
\hline $\begin{array}{l}\text { Com registro, laudo, sem } \\
\text { Câmina e sem bloco }\end{array}$ & & & & & & & & & \\
\hline $\begin{array}{l}\text { Com registro, sem laudo, } \\
\text { sem lâmina e sem bloco }\end{array}$ & & & & & & & & & \\
\hline $\begin{array}{c}\text { Sem registro, sem laudo, } \\
\text { sem lâmina e sem bloco }\end{array}$ & & & & & & & & & \\
\hline $\begin{array}{c}\text { Com registro, laudo, sem } \\
\text { Câmina e com bloco }\end{array}$ & & & & & & & & & \\
\hline Total de casos sem lâmina & & & & & & & & & \\
\hline Total de casos sem blocos & & & & & & & & & \\
\hline $\begin{array}{l}\text { Total de casos sem laudos, } \\
\text { mas com lâminas e blocos }\end{array}$ & & & & & & & & & \\
\hline $\begin{array}{l}\text { Total de lâminas não } \\
\text { passíve is de análise }\end{array}$ & & & & & & & & & \\
\hline
\end{tabular}

d. Classificação dos diagnósticos efetuados de acordo com a qualidade/quantidade do material enviado para análise a cada ano de atividade do Serviço de Anatomia Patológic a da FOB/US P 
Após selecionados, os casos com origem bucal e peribucal foram avaliados e quantificados os que apresentavam material adequado à análise microscópica e aqueles que impossibilitavam esta análise. Foram class ificados e registrados na figura a seguir:

\begin{tabular}{|l|l|l|l|l|l|l|l|l|l|l|l|}
\hline \multicolumn{1}{|c|}{ Ano } & $\mathcal{A n o}$ & $\mathcal{A} n o$ & $\mathcal{A n o}$ & $\mathcal{A} n o$ & $\mathcal{A} n o$ & $\mathcal{A n o}$ & Ano & Ano & Ano & Ano & Ano \\
\hline $\mathcal{A d e q u a d o}$ & & & & & & & & & & & \\
\hline $\mathcal{N}$ ão adequado & & & & & & & & & & & \\
\hline
\end{tabular}

e. Classificação dos diagnósticos efetuados de acordo com sua forma de apresentação a cada ano do Serviço de Anatomia Patológica Buc al d a FOB $/ \mathcal{U S P}$

$\mathcal{A}$ partir do resgate dos laudos emitidos verificou-se não só a presença como a característica do diagnóstico final. Foi considerado diagnóstico conclusivo, o determinante do tipo de lesão, e descritivo, quando dissertando sobre os aspectos microscópicos encontrados. Os dados obtidos foram colocados em figura como no modelo abaixo:

\begin{tabular}{|c|c|c|c|c|c|c|c|c|c|c|c|}
\hline Ano & Ano & Ano & Ano & Ano & Ano & Ano & Ano & Ano & Ano & Ano & Ano \\
\hline $\begin{array}{l}\text { Diagnóstica } \\
\text { conclusivo }\end{array}$ & & & & & & & & & & & \\
\hline $\begin{array}{l}\text { Diagnóstica } \\
\text { descritivo }\end{array}$ & & & & & & & & & & & \\
\hline Ausente & & & & & & & & & & & \\
\hline
\end{tabular}


f. Classificação dos diagnósticos efetuados quanto a sua condizibilidade com a nomenclatura atual, a cada ano do Serviço de Anatomia Patológic a Bucal da FOB $/ \mathcal{H} \mathcal{P}$

Os diagnósticos conclusivos foram avaliados em relação à nomenclatura usada na literatura atual. A terminologia utilizada foi incluida em tabelas e transcrita lite ralmente como estavam nos laudos analisados. Os dados obtidos foram distribuídos como mostra a figura a seguir:

\begin{tabular}{|c|c|c|c|c|c|c|c|c|c|c|c|}
\hline Ano & Ano & Ano & Ano & Ano & Ano & Ano & Ano & Ano & Ano & Ano & Ano \\
\hline $\begin{array}{c}\text { Diagnósticos } \\
\text { condizentes }\end{array}$ & & & & & & & & & & & \\
\hline $\begin{array}{c}\text { Diagnósticos } \\
\text { não } \\
\text { condizentes }\end{array}$ & & & & & & & & & & & \\
\hline
\end{tabular}

A condizibilidade terminológic a foi de terminada pela freqüência do uso e coerência de sua aplicação com a etiopatogenia do processo patológico caracterizador da doença diagnosticada.

g. Classificação dos diagnósticos efetuados de acordo com a sua checagem frente ao confecimento atual, a cada ano do Serviço de Anatomia Patológic a Bucal da FOB/USP 
Os diagnósticos dados foram avaliados após revisão criteriosa dos cortes microscópicos e consulta à literatura atualizada, sendo confirmados ou revistos quando necessário. Os resultados numéricos foram colocados em figuras como o modelo a seguir:

\begin{tabular}{|c|c|c|c|c|c|c|c|c|c|c|c|}
\hline Ano & Ano & Ano & Ano & Ano & Ano & Ano & Ano & Ano & Ano & Ano & Ano \\
\hline $\begin{array}{c}\text { Diagnósticos } \\
\text { confirmados }\end{array}$ & & & & & & & & & & & \\
\hline $\begin{array}{c}\text { Diagnósticos } \\
\text { revistos }\end{array}$ & & & & & & & & & & & \\
\hline
\end{tabular}

\subsection{Acesso aos arquivos e sua reorganização}

O acesso aos documentos e provas documentais foi restrito aos pesquisadores envolvidos e aos demais normalmente participantes do ciclo diagnóstico da rotina do Serviço de Anatomia Patológica da $\mathcal{F O B} / \mathcal{U} S$ P. Esse acesso por questões éticas, legais, administrativas e organizacionais não é permitido a pessoas não participantes do processo ou ciclo diagnós tico de finido na introdução.

Os armários, arquivos e formas de registros foram modificados a partir de novas aquisições materiais e treinamento dos recursos fumanos envolvidos. 


\subsection{Aspectos éticos, legais e institucionais}

$\mathcal{N a}$ o foi obje tivo desse trabalho correlacionar os resultados com os aspectos éticos, legais e institucionais e sim restringir a discussão dos dados aos aspectos filosóficos e técnicos inerentes a prática da Patologia Bucal enquanto especialidade odontológica e área do confecimento fumano a serem transmitidas entre as gerações.

Os dados quanto às assinaturas e responsabilidade dos laudos e mitidos, bem como do clínico que recebeu os laudos, especialmente os revisados, foram levantados mas propositadamente serão omitidos.

Os clínicos responsáveis pelos procedimentos cirúrgicos e pelas peças enviadas para os diagnósticos checados e revistos receberão após o término do trabalho uma carta de retificação com considerações explicativas. Para tal, será considerado término do trabalho sua defesa pública. 
5 RES ULT ADOS 
5. Resultados

As taxas que sinte tizam os resultados foram obtidas a partir de diversos universos de amostra. A avaliação se fará inicialmente da figura 1 à figura 7, a cada ano do Serviço de Anatomia Patológica da $\mathcal{F O B} / \mathcal{U S} \mathcal{P}$ e no final o equivalente aos 37 anos do Serviço. Na figura 1 o universo da amostra consiste do total de exames recebidos. Na figura 2, os exames referentes a tecidos fumanos passam a representar o universo da amostra. A partir da figura 3 à figura 7 , o total de exames bucais se torna o universo da amostra. Nas figuras 8 e 9 o percentual será calculado em relação ao total de exames bucais recebidos no decorrer dos 37 anos do Serviço de Anatomia Patológica da FOB/USP. Também nestas duas figuras se fará o percentual tendo como base o total de diagnósticos não condizentes com a nomenclatura atual e o total de diagnósticos revistos por grupo de lesões respectivamente. 
5.1 Da espécie de origem do material cole tado a cada ano de atividade.

$\mathcal{N o}$ início de implantação do Serviço de Anatomia Patológica da

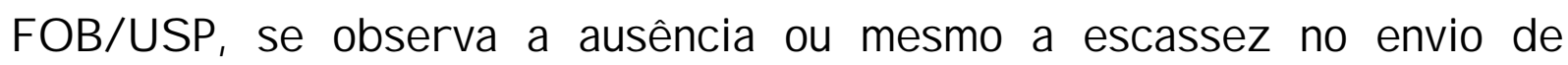
espécimes de animais irracionais. Podemos considerar 1985 como o início da integração do Serviço com os centros de veterinária, atingindo o seu auge entre 1997 e 1999. O envio de espécimes fumanos foi crescente, chegando a 1314 espécimes no ano 2000. Assim, temos uma média de 109 espécimes processados no mês (figura 1).

\begin{tabular}{|c|c|c|c|c|c|c|c|c|c|c|c|c|c|}
\hline Ano & 1963 & 1964 & 1965 & 1966 & 1967 & 1968 & 1969 & 1970 & 1971 & 1972 & 1973 & 1974 & 1975 \\
\hline \multirow{2}{*}{ Humano } & 108 & 91 & 85 & 110 & 147 & 50 & 87 & 244 & 81 & 160 & 135 & 139 & 222 \\
\hline & $100 \%$ & $100 \%$ & $100 \%$ & $100 \%$ & $100 \%$ & $100 \%$ & $100 \%$ & $100 \%$ & $98,8 \%$ & $98,8 \%$ & $100 \%$ & $100 \%$ & $100 \%$ \\
\hline \multirow{2}{*}{ Animal } & 0 & 0 & 0 & 0 & 0 & 0 & 0 & 0 & 1 & 2 & 0 & 0 & 0 \\
\hline & - & - & - & - & - & - & - & - & $1,2 \%$ & $1,2 \%$ & - & - & - \\
\hline
\end{tabular}

\begin{tabular}{|c|c|c|c|c|c|c|c|c|c|c|c|c|c|}
\hline \multirow{2}{*}{ Ano } & 1976 & 1977 & 1978 & 1979 & 1980 & 1981 & 1982 & 1983 & 1984 & 1985 & 1986 & 1987 & 1988 \\
\hline \multirow{2}{*}{ Humano } & 222 & 255 & 237 & 173 & 283 & 263 & 298 & 288 & 287 & 332 & 319 & 394 & 328 \\
\cline { 2 - 40 } & $100 \%$ & $100 \%$ & $100 \%$ & $100 \%$ & $100 \%$ & $99,6 \%$ & $100 \%$ & $100 \%$ & $100 \%$ & $95,4 \%$ & $100 \%$ & $98,5 \%$ & $99,7 \%$ \\
\hline \multirow{2}{*}{ Animal } & 0 & 0 & 0 & 0 & 0 & 1 & 0 & 0 & 0 & 16 & 0 & 6 & 1 \\
\cline { 2 - 14 } & - & - & - & - & - & $0,4 \%$ & - & - & - & $4,6 \%$ & - & $1,5 \%$ \\
\hline
\end{tabular}

\begin{tabular}{|c|c|c|c|c|c|c|c|c|c|c|c|c|c|}
\hline Ano & 1989 & 1990 & 1991 & 1992 & 1993 & 1994 & 1995 & 1996 & 1997 & 1998 & 1999 & 2000 & Total \\
\hline \multirow{2}{*}{ Humano } & 468 & 321 & 271 & 406 & 367 & 407 & 556 & 624 & 776 & 1069 & 1223 & 1314 & 13140 \\
\hline & $99,6 \%$ & $97,3 \%$ & $97,5 \%$ & $99 \%$ & $99,4 \%$ & $99,7 \%$ & $99,1 \%$ & $98,7 \%$ & $96,6 \%$ & $92,1 \%$ & $94,6 \%$ & $99,5 \%$ & $98,3 \%$ \\
\hline \multirow{2}{*}{ Animal } & 2 & 9 & 7 & 4 & 2 & 1 & 5 & 8 & 27 & 92 & 69 & 7 & 260 \\
\hline & $0,4 \%$ & $2,7 \%$ & $2,5 \%$ & $1,0 \%$ & $0,5 \%$ & $0,2 \%$ & $0,9 \%$ & $1,3 \%$ & $3,3 \%$ & $7,9 \%$ & $5,3 \%$ & $0,5 \%$ & $1,9 \%$ \\
\hline
\end{tabular}

FIGURA 1 - Classificação dos diagnósticos efetuados de acordo com a espécie de origem do material coletado a cada ano de atividade do Serviço de Anatomia Patológic a da FOB/US $P$ 
$5.2 \mathcal{D a}$ origem e tipo do material em relação à boca coletado a cada ano de atividade

Os dados dispostos na figura 2 permitem constatar um maior envio de espécimes não bucais quando da implantação do Serviço de Anatomia Patológica da FOB/USP. $\mathcal{N}$ o decorrer dos anos se observa uma diluição desse tipo de amostra, predominando enfaticamente os espécimes bucais. Os esfregaços em 1972 têm seu maior número de casos, posteriormente decaindo e se mantendo em um patamar linear a partir de 1998 (Figura 2).

\begin{tabular}{|c|c|c|c|c|c|c|c|c|c|c|c|c|c|}
\hline Ano & 1963 & 1964 & 1965 & 1966 & 1967 & 1968 & 1969 & 1970 & 1971 & 1972 & 1973 & 1974 & 1975 \\
\hline \multirow{2}{*}{ Bucal } & 20 & 53 & 25 & 43 & 136 & 35 & 72 & 209 & 78 & 103 & 130 & 130 & 211 \\
\hline & $18,5 \%$ & $58,2 \%$ & $29,4 \%$ & $39 \%$ & $92,5 \%$ & $70 \%$ & $82,8 \%$ & $85,6 \%$ & $96,3 \%$ & $64,4 \%$ & $96,3 \%$ & $93,5 \%$ & $95 \%$ \\
\hline \multirow{2}{*}{$\mathcal{N}$ ão bucal } & 73 & 32 & 60 & 67 & 11 & 15 & 14 & 35 & 4 & 16 & 2 & 4 & 8 \\
\hline & $67,6 \%$ & $35,2 \%$ & $70,6 \%$ & $60,9 \%$ & $7,5 \%$ & $30 \%$ & $16 \%$ & $14,3 \%$ & $4,9 \%$ & $10 \%$ & $1,5 \%$ & $2,9 \%$ & $3,6 \%$ \\
\hline \multirow{2}{*}{ Esfregaço } & 15 & 6 & 0 & 0 & 0 & 0 & 1 & 0 & 0 & 41 & 3 & 5 & 3 \\
\hline & $13,9 \%$ & $6,6 \%$ & - & 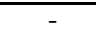 & - & - & $1 \%$ & - & - & $25,6 \%$ & $2,2 \%$ & $3,6 \%$ & $1,35 \%$ \\
\hline
\end{tabular}

\begin{tabular}{|c|c|c|c|c|c|c|c|c|c|c|c|c|c|}
\hline Ano & 1976 & 1977 & 1978 & 1979 & 1980 & 1981 & 1982 & 1983 & 1984 & 1985 & 1986 & 1987 & 1988 \\
\hline \multirow{2}{*}{ Bucal } & 211 & 249 & 229 & 172 & 281 & 257 & 283 & 270 & 268 & 312 & 303 & 367 & 301 \\
\hline & $95 \%$ & $97,6 \%$ & $96,6 \%$ & $99,4 \%$ & $99,3 \%$ & $97,7 \%$ & $94,9 \%$ & $93,7 \%$ & $93,4 \%$ & $94 \%$ & $95 \%$ & $93 \%$ & $91,8 \%$ \\
\hline \multirow{2}{*}{$\mathcal{N}$ ão $\quad b u c a l$} & 5 & 2 & 1 & 1 & 2 & 2 & 12 & 15 & 7 & 7 & 10 & 12 & 10 \\
\hline & $2,3 \%$ & $0,8 \%$ & $0,4 \%$ & $0,6 \%$ & $0,7 \%$ & $0,8 \%$ & $4 \%$ & $5,2 \%$ & $2,4 \%$ & $2 \%$ & $3 \%$ & $3 \%$ & $3 \%$ \\
\hline \multirow{2}{*}{ Esfregaço } & 6 & 4 & 7 & 0 & 2 & 4 & 3 & 3 & 12 & 13 & 6 & 15 & 17 \\
\hline & $2,7 \%$ & $1,6 \%$ & $2,9 \%$ & - & $0,7 \%$ & $1,5 \%$ & $1 \%$ & $1 \%$ & $4,2 \%$ & $3,9 \%$ & $1,9 \%$ & $3,8 \%$ & $5,2 \%$ \\
\hline
\end{tabular}

FIGURA 2 - Classific ação dos diagnósticos efetuados de acordo com a origem e tipo do material em relação à boca coletado a cada ano de atividade do Serviço de Anatomia Patológica da FOB/CISP (continua) 


\begin{tabular}{|c|c|c|c|c|c|c|c|c|c|c|c|c|c|}
\hline Ano & 1989 & 1990 & 1991 & 1992 & 1993 & 1994 & 1995 & 1996 & 1997 & 1998 & 1999 & 2000 & Total \\
\hline \multirow{2}{*}{ Bucal } & 412 & 278 & 232 & 344 & 337 & 379 & 521 & 599 & 741 & 996 & 1160 & 1241 & 11988 \\
\hline & $88 \%$ & $86,6 \%$ & $85,6 \%$ & $84,7 \%$ & $91,8 \%$ & $93 \%$ & $93,7 \%$ & $96 \%$ & $95,5 \%$ & $93,2 \%$ & $94,8 \%$ & $94,4 \%$ & $91,2 \%$ \\
\hline \multirow{2}{*}{$\mathcal{N}$ ão $\quad b u c a l$} & 26 & 29 & 26 & 45 & 23 & 17 & 23 & 19 & 27 & 46 & 36 & 45 & 789 \\
\hline & $5,5 \%$ & $9 \%$ & $9,6 \%$ & $11 \%$ & $6,3 \%$ & $4,2 \%$ & $4,1 \%$ & $3 \%$ & $3,5 \%$ & $4,3 \%$ & $2,9 \%$ & $3,4 \%$ & $6 \%$ \\
\hline \multirow{2}{*}{ Esfregaço } & 30 & 14 & 13 & 17 & 7 & 11 & 12 & 6 & 8 & 27 & 27 & 28 & 291 \\
\hline & $6,4 \%$ & $4,4 \%$ & $4,8 \%$ & $4,2 \%$ & $1,9 \%$ & $2,7 \%$ & $2,1 \%$ & $1 \%$ & $1 \%$ & $2,5 \%$ & $2,2 \%$ & $2,1 \%$ & $2,2 \%$ \\
\hline
\end{tabular}

5.3 Do resgate das provas documentais e/ou material dos diagnósticos efetuados a cada ano de atividade

$\mathcal{A}$ maioria dos exames apresenta sua documentação completa, constando de registro, laudo, bloco e lâmina. Em alguns, podemos observar a ausência de um ou mais dados. Poucos e diluídos pelo decorrer dos anos são os que apresentam a falta de todos os dados, impossibilitando sua resolução. Os exames com lâminas não passíveis de análise pertencem aos nove primeiros anos do Serviço e praticamente inexistem nos demais. Ainda se observam a partir de 1991 exames com registro, mas sem os demais documentos, tendo sua maior expressão em 1992. Os anos de 1997 a 2000 têm maior número de casos sem lâminas e blocos. O total de exames sem lâminas aumenta a partir de 1989 e tem sua maior expressividade em 1998 e 1999. Outro dado constatado é a presença de exames com registro, laudo, mas sem lâmina e bloco de 
1989 a 1999, com maior número de casos nos anos de 1990,1993,1998

e 1999 (Figura 3).

\begin{tabular}{|c|c|c|c|c|c|c|c|c|c|c|c|c|c|}
\hline Situação /Ano & 1963 & 1964 & 1965 & 1966 & 1967 & 1968 & 1969 & 1970 & 1971 & 1972 & 1973 & 1974 & 1975 \\
\hline \multirow{2}{*}{$\begin{array}{c}\text { Com registro, laudo, } \\
\text { Câmina e bloco }\end{array}$} & 13 & 50 & 19 & 32 & 117 & 32 & 69 & 195 & 72 & 92 & 127 & 125 & 205 \\
\hline & $65 \%$ & $94,3 \%$ & $76 \%$ & $74,4 \%$ & $86 \%$ & $91,4 \%$ & $95,8 \%$ & $93,3 \%$ & $92,3 \%$ & $89,3 \%$ & $97,7 \%$ & $96 \%$ & $97 \%$ \\
\hline \multirow{2}{*}{$\begin{array}{l}\text { Com registro, laudo, } \\
\text { lâmina e sem bloco }\end{array}$} & 4 & 1 & 5 & 8 & 12 & 2 & 1 & 13 & 1 & 11 & 2 & 4 & 5 \\
\hline & $20 \%$ & $1,9 \%$ & $20 \%$ & $18,6 \%$ & $8,8 \%$ & $5,7 \%$ & $1,4 \%$ & $6,2 \%$ & $1,3 \%$ & $10,7 \%$ & $1,5 \%$ & $3 \%$ & $2,4 \%$ \\
\hline \multirow{2}{*}{$\begin{array}{l}\text { Com registro, laudo, sem } \\
\text { lâmina e sem bloco }\end{array}$} & 1 & 0 & 0 & 0 & 1 & 1 & 0 & 0 & 0 & 0 & 0 & 0 & 0 \\
\hline & $5 \%$ & - & - & - & $0,7 \%$ & $2,8 \%$ & - & - & - & - & - & - & - \\
\hline \multirow{2}{*}{$\begin{array}{l}\text { Com registro, sem laudo, } \\
\text { sem lâmina e sem bloco }\end{array}$} & 0 & 0 & 0 & 0 & 0 & 0 & 0 & 0 & 0 & 0 & 0 & 0 & 0 \\
\hline & - & - & - & - & - & 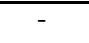 & - & - & - & - & - & - & - \\
\hline \multirow{2}{*}{$\begin{array}{l}\text { Sem registro, sem laudo, } \\
\text { sem lâmina e sem bloco }\end{array}$} & 0 & 0 & 0 & 0 & 2 & 0 & 0 & 0 & 3 & 0 & 0 & 0 & 0 \\
\hline & - & - & - & - & $1,5 \%$ & - & - & - & $3,9 \%$ & - & - & - & - \\
\hline \multirow{2}{*}{$\begin{array}{l}\text { Com registro, laudo, sem } \\
\text { lâmina e com bloco }\end{array}$} & 2 & 2 & 1 & 3 & 3 & 0 & 2 & 1 & 2 & 0 & 1 & 1 & 1 \\
\hline & $10 \%$ & $3,8 \%$ & $4 \%$ & $7 \%$ & $2,2 \%$ & $\overline{-}$ & $2,8 \%$ & $0,5 \%$ & $2,6 \%$ & - & $0,8 \%$ & $0,8 \%$ & $0,5 \%$ \\
\hline \multirow{2}{*}{ Total de casos sem lâmina } & 3 & 2 & 1 & 3 & 6 & 1 & 2 & 1 & 5 & 0 & 1 & 1 & 1 \\
\hline & $15 \%$ & $3,8 \%$ & $4 \%$ & $7 \%$ & $4,4 \%$ & $2,8 \%$ & $2,8 \%$ & $0,5 \%$ & $6,4 \%$ & - & $0,8 \%$ & $0,8 \%$ & $0,5 \%$ \\
\hline \multirow{2}{*}{ Totalde casos sem blocos } & 5 & 0 & 5 & 8 & 19 & 3 & 1 & 13 & 4 & 11 & 2 & 4 & 5 \\
\hline & $25 \%$ & & $20 \%$ & $18,6 \%$ & $14 \%$ & $8,6 \%$ & $1,4 \%$ & $6,2 \%$ & $5 \%$ & $10,7 \%$ & $1,5 \%$ & $3 \%$ & $2,4 \%$ \\
\hline \multirow{2}{*}{$\begin{array}{c}\text { Total de casos sem laudos, } \\
\text { mas com lâminas e blocos }\end{array}$} & 0 & 0 & 0 & 0 & 1 & 0 & 0 & 0 & 0 & 0 & 0 & 0 & 0 \\
\hline & - & - & - & - & $0,7 \%$ & - & - & - & - & - & - & - & - \\
\hline \multirow{2}{*}{$\begin{array}{l}\text { Total de lâminas não } \\
\text { passive is de análise }\end{array}$} & 0 & 0 & 2 & 3 & 2 & 4 & 1 & 3 & 3 & 0 & 1 & 0 & 0 \\
\hline & - & - & $8 \%$ & $7 \%$ & $1,5 \%$ & $11,4 \%$ & $1,4 \%$ & $1,4 \%$ & $3,9 \%$ & - & $0,8 \%$ & - & - \\
\hline
\end{tabular}

FIGURA 3 - Classificação dos diagnósticos efetuados quanto ao resgate das suas provas documentais e/ou materiais a cada ano de atividade do Serviço de Anatomia Patológic a da FOB/CLSP (continua) 


\begin{tabular}{|c|c|c|c|c|c|c|c|c|c|c|c|c|c|}
\hline Situação / Ano & 1976 & 1977 & 1978 & 1979 & 1980 & 1981 & 1982 & 1983 & 1984 & 1985 & 1986 & 1987 & 1988 \\
\hline \multirow{2}{*}{$\begin{array}{c}\text { Com registro, laudo, } \\
\text { lâmina e bloco }\end{array}$} & 206 & 240 & 225 & 168 & 276 & 254 & 280 & 266 & 259 & 290 & 299 & 349 & 284 \\
\hline & $97,6 \%$ & $96,4 \%$ & $98,2 \%$ & $97,7 \%$ & $98,2 \%$ & $98,8 \%$ & $98,9 \%$ & $98,5 \%$ & $96,6 \%$ & $92,6 \%$ & $98,7 \%$ & $95 \%$ & $94,3 \%$ \\
\hline \multirow{2}{*}{$\begin{array}{l}\text { Com registro, laudo, } \\
\text { lâmina e sem bloco }\end{array}$} & 3 & 7 & 2 & 3 & 4 & 0 & 1 & 2 & 5 & 18 & 2 & 13 & 6 \\
\hline & $1,4 \%$ & $2,8 \%$ & $0,9 \%$ & $1,8 \%$ & $1,4 \%$ & - & $0,3 \%$ & $0,7 \%$ & $1,9 \%$ & $5,8 \%$ & $0,6 \%$ & $3,5 \%$ & $1,9 \%$ \\
\hline $\begin{array}{c}\text { Com registro, laudo, sem } \\
\text { Câmina e sem bloco }\end{array}$ & 0 & 0 & 0 & 0 & 0 & 0 & 1 & 0 & 0 & 0 & 0 & 1 & 3 \\
\hline \multirow{2}{*}{$\begin{array}{l}\text { Com registro, sem laudo, } \\
\text { sem lâmina e sem bloco }\end{array}$} & 0 & 0 & 0 & 0 & 0 & 0 & 0 & 0 & 0 & 0 & 0 & 0 & 0 \\
\hline & - & - & - & - & - & - & - & - & - & - & - & - & - \\
\hline \multirow{2}{*}{$\begin{array}{l}\text { Sem registro, sem laudo, } \\
\text { sem lâmina e sem bloco }\end{array}$} & 2 & 1 & 1 & 1 & 0 & 3 & 1 & 2 & 4 & 4 & 1 & 3 & 6 \\
\hline & $0,9 \%$ & $0,4 \%$ & $0,4 \%$ & $0,6 \%$ & - & $1,2 \%$ & $0,3 \%$ & $0,7 \%$ & $1,5 \%$ & $1,3 \%$ & $0,3 \%$ & $0,8 \%$ & $1,9 \%$ \\
\hline \multirow{2}{*}{$\begin{array}{l}\text { Com registro, laudo, sem } \\
\text { lâmina e com bloco }\end{array}$} & 0 & 1 & 1 & 0 & 0 & 0 & 0 & 0 & 0 & 0 & 0 & 1 & 2 \\
\hline & - & $0,4 \%$ & $0,4 \%$ & - & - & - & - & - & - & - & - & $0,3 \%$ & $0,6 \%$ \\
\hline Total de casos sem lâmina & $0,9 \%$ & $0,8 \%$ & $0,9 \%$ & $0,6 \%$ & - & $1,2 \%$ & $0,7 \%$ & $0,7 \%$ & $1,5 \%$ & $1,3 \%$ & $0,3 \%$ & $1,4 \%$ & $1,9 \%$ \\
\hline \multirow{2}{*}{ Total de casos sem blocos } & 5 & 8 & 3 & 4 & 4 & 3 & 3 & 4 & 9 & 22 & 3 & 17 & 10 \\
\hline & $2,4 \%$ & $3,2 \%$ & $1,3 \%$ & $2,3 \%$ & $1,4 \%$ & $1,2 \%$ & $1 \%$ & $1,5 \%$ & $3,4 \%$ & $7 \%$ & $0,9 \%$ & $4,6 \%$ & $3,3 \%$ \\
\hline $\begin{array}{l}\text { Totalde casos sem laudos, } \\
\text { mas com lâminas e blocos }\end{array}$ & 0 & 0 & 0 & 0 & $\begin{array}{c}1 \\
0,4 \%\end{array}$ & 0 & 0 & 0 & 0 & 0 & 0 & 0 & 0 \\
\hline $\begin{array}{l}\text { Total de lâminas não } \\
\text { passíve is de análise }\end{array}$ & 0 & 0 & 0 & $\begin{array}{c}1 \\
0,6 \%\end{array}$ & 0 & 0 & 0 & 0 & $\begin{array}{c}2 \\
0,7 \%\end{array}$ & 0 & $\begin{array}{c}1 \\
0,3 \%\end{array}$ & $\begin{array}{l}0 \\
-\end{array}$ & $\begin{array}{l}0 \\
-\end{array}$ \\
\hline
\end{tabular}

\begin{tabular}{|c|c|c|c|c|c|c|c|c|c|c|c|c|c|}
\hline S ituação / A no & 1989 & 1990 & 1991 & 1992 & 1993 & 1994 & 1995 & 1996 & 1997 & 1998 & 1999 & 2000 & Total \\
\hline \multirow{2}{*}{$\begin{array}{c}\text { Com registro, laudo, } \\
\text { lâmina e bloco }\end{array}$} & 400 & 240 & 219 & 317 & 306 & 353 & 485 & 574 & 680 & 881 & 1030 & 1136 & 11165 \\
\hline & $97 \%$ & $86,3 \%$ & $94,4 \%$ & $92 \%$ & $90,8 \%$ & $93 \%$ & $93 \%$ & $95,8 \%$ & $91,8 \%$ & $88,4 \%$ & $88,8 \%$ & $91,5 \%$ & $93 \%$ \\
\hline \multirow{2}{*}{$\begin{array}{l}\text { Com registro, laudo, } \\
\text { lâmina e sem bloco }\end{array}$} & 3 & 6 & 4 & 13 & 10 & 17 & 12 & 2 & 25 & 64 & 64 & 63 & 418 \\
\hline & $0,7 \%$ & $2,1 \%$ & $1,4 \%$ & $3,8 \%$ & $2,6 \%$ & $4,5 \%$ & $2,3 \%$ & $0,3 \%$ & $3,4 \%$ & $6,4 \%$ & $5,5 \%$ & $5 \%$ & $3,5 \%$ \\
\hline \multirow{2}{*}{$\begin{array}{l}\text { Com registro, laudo, sem } \\
\text { lâmina e sem bloco }\end{array}$} & 3 & 10 & 1 & 3 & 13 & 0 & 3 & 0 & 2 & 15 & 19 & 1 & 77 \\
\hline & $0,7 \%$ & $3,6 \%$ & $0,4 \%$ & $0,9 \%$ & $3,8 \%$ & - & $0,6 \%$ & - & $0,3 \%$ & $1,5 \%$ & $1,6 \%$ & $0,08 \%$ & $0,64 \%$ \\
\hline \multirow{2}{*}{$\begin{array}{l}\text { Com registro, sem laudo, } \\
\text { sem lâmina e sem bloco }\end{array}$} & 0 & 0 & 2 & 4 & 0 & 1 & 0 & 2 & 4 & 1 & 1 & 0 & 16 \\
\hline & - & - & $0,9 \%$ & $1,2 \%$ & . & $0,3 \%$ & - & $0,3 \%$ & $0,5 \%$ & $0,1 \%$ & $0,08 \%$ & 0 & $0,13 \%$ \\
\hline \multirow{2}{*}{$\begin{array}{l}\text { Sem registro, sem laudo, } \\
\text { sem lâmina e sem bloco }\end{array}$} & 4 & 0 & 0 & 0 & 0 & 0 & 0 & 0 & 0 & 1 & 2 & 0 & 41 \\
\hline & $1 \%$ & - & - & - & - & - & - & - & - & $0,1 \%$ & $0,2 \%$ & - & $0,34 \%$ \\
\hline \multirow{2}{*}{$\begin{array}{l}\text { Com registro, laudo, sem } \\
\text { lâmina e com bloco }\end{array}$} & 2 & 22 & 6 & 7 & 8 & 8 & 12 & 15 & 29 & 34 & 44 & 41 & 252 \\
\hline & $0,5 \%$ & $7,9 \%$ & $2,6 \%$ & $2,0 \%$ & $2,4 \%$ & $2,1 \%$ & $2,3 \%$ & $2,5 \%$ & $3,9 \%$ & $3,4 \%$ & $3,8 \%$ & $3,3 \%$ & $2 \%$ \\
\hline Total de casos sem lâmina & 9 & 32 & 9 & 14 & 21 & 9 & 15 & 17 & 35 & 51 & 66 & 42 & 381 \\
\hline \multirow{2}{*}{ Total de casos sem blocos } & 10 & 16 & 7 & 20 & 23 & 18 & 15 & 4 & 31 & 81 & 86 & 64 & 470 \\
\hline & $2,6 \%$ & $5,7 \%$ & $3 \%$ & $5,8 \%$ & $6,8 \%$ & $4,7 \%$ & $2,9 \%$ & $0,7 \%$ & $4,2 \%$ & $8,1 \%$ & $7,4 \%$ & $5 \%$ & $3,9 \%$ \\
\hline \multirow{2}{*}{$\begin{array}{l}\text { Total de casos sem laudos, } \\
\text { mas com lâminas e blocos }\end{array}$} & 0 & 0 & 0 & 0 & 0 & 0 & 9 & 6 & 1 & 0 & 0 & 0 & 18 \\
\hline & - & - & - & - & - & - & $1,7 \%$ & $1 \%$ & $0,1 \%$ & - & - & - & $0,15 \%$ \\
\hline \multirow{2}{*}{$\begin{array}{l}\text { Total de lâminas não } \\
\text { passíve is de análise }\end{array}$} & 0 & 0 & 0 & 0 & 0 & 0 & 0 & 0 & 0 & 0 & 0 & 0 & 23 \\
\hline & - & - & - & - & - & - & - & - & - & - & - & - & $0,19 \%$ \\
\hline
\end{tabular}


5.4 Do material enviado para análise e m relação à qualidade/quantidade a cada ano de atividade

$\mathcal{N o}$ período de 37 anos do Serviço de Anatomia Patológica da $\mathcal{F O B} / \mathcal{U S} P$ predominou o envio de material com qualidade e quantidade suficiente para uma análise criteriosa, bem como um diagnóstico confiável. Em 1972 se observa o registro do maior número de casos com material inade quado, totalizando 8 casos (Figura 4).

\begin{tabular}{|c|c|c|c|c|c|c|c|c|c|c|c|c|c|}
\hline Ano & 1963 & 1964 & 1965 & 1966 & 1967 & 1968 & 1969 & 1970 & 1971 & 1972 & 1973 & 1974 & 1975 \\
\hline \multirow{2}{*}{ Ade quado } & 20 & 51 & 24 & 41 & 130 & 34 & 72 & 205 & 72 & 95 & 130 & 130 & 210 \\
\hline & $100 \%$ & $96,2 \%$ & $96 \%$ & $95,3 \%$ & $95,6 \%$ & $97 \%$ & $100 \%$ & $98 \%$ & $92,3 \%$ & $92,2 \%$ & $100 \%$ & $100 \%$ & $99,5 \%$ \\
\hline \multirow{2}{*}{$\begin{array}{c}\mathcal{N a \tilde { a } o} \\
\text { adequado }\end{array}$} & 0 & 2 & 1 & 2 & 4 & 1 & 0 & 4 & 3 & 8 & 0 & 0 & 1 \\
\hline & 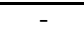 & $3,8 \%$ & $4 \%$ & $4,6 \%$ & $2,9 \%$ & $2,8 \%$ & - & $1,9 \%$ & $3,8 \%$ & $7,8 \%$ & - & - & $0,5 \%$ \\
\hline
\end{tabular}

\begin{tabular}{|c|c|c|c|c|c|c|c|c|c|c|c|c|c|}
\hline $\mathcal{A}$ no & 1976 & 1977 & 1978 & 1979 & 1980 & 1981 & 1982 & 1983 & 1984 & 1985 & 1986 & 1987 & 1988 \\
\hline \multirow{2}{*}{ Adequado } & 209 & 248 & 224 & 170 & 279 & 253 & 277 & 267 & 263 & 308 & 295 & 364 & 291 \\
\hline & $99 \%$ & $99,6 \%$ & $97,8 \%$ & $98,8 \%$ & $99,3 \%$ & $98,4 \%$ & $97,9 \%$ & $98,8 \%$ & $98 \%$ & $98,7 \%$ & $97,3 \%$ & $99,2 \%$ & $96,7 \%$ \\
\hline \multirow{2}{*}{$\begin{array}{c}\mathcal{N} \text { ão } \\
\text { adequado }\end{array}$} & 0 & 0 & 4 & 1 & 2 & 1 & 5 & 1 & 1 & 0 & 7 & 0 & 4 \\
\hline & 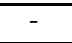 & 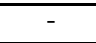 & $1,7 \%$ & $0,6 \%$ & $0,7 \%$ & $0,4 \%$ & $1,8 \%$ & $0,4 \%$ & $0,4 \%$ & 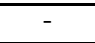 & $2,3 \%$ & 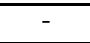 & $1,3 \%$ \\
\hline
\end{tabular}

\begin{tabular}{|c|c|c|c|c|c|c|c|c|c|c|c|c|c|}
\hline $\mathcal{A}$ no & 1989 & 1990 & 1991 & 1992 & 1993 & 1994 & 1995 & 1996 & 1997 & 1998 & 1999 & 2000 & Total \\
\hline \multirow{2}{*}{ Adequado } & 402 & 276 & 229 & 337 & 336 & 378 & 520 & 597 & 737 & 991 & 1155 & 1236 & 11856 \\
\hline & $97,6 \%$ & $99,3 \%$ & $98,7 \%$ & $97,9 \%$ & $99,7 \%$ & $99,7 \%$ & $99,8 \%$ & $99,6 \%$ & $99,5 \%$ & $99,5 \%$ & $99,6 \%$ & $99,6 \%$ & $98,9 \%$ \\
\hline \multirow{2}{*}{$\begin{array}{c}\mathcal{N} \text { (ão } \\
\text { adequado }\end{array}$} & 6 & 2 & 1 & 3 & 1 & 0 & 1 & 0 & 0 & 3 & 2 & 4 & 75 \\
\hline & $1,4 \%$ & $0,7 \%$ & $0,4 \%$ & $0,9 \%$ & $0,3 \%$ & - & $0,2 \%$ & 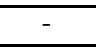 & 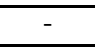 & $0,3 \%$ & $0,2 \%$ & $0,3 \%$ & $0,6 \%$ \\
\hline
\end{tabular}

FIGURA 4 - Classificação dos diagnósticos efetuados de acordo com a qualidade/quantidade do material enviado para análise a cada ano de atividade do Serviço de Anatomia Patológic a da FOB $\mathcal{B} / \mathcal{U} \mathcal{P}$ 
5.5 Da forma de apresentação dos diagnósticos efe tuados a cada ano de atividade

Os diagnósticos conclusivos predominam em todos os anos do Serviço de Anatomia Patológica da FOB/USP. Em 1985, 1986,1987 , 1988 e 1998 se observa um maior número de diagnósticos descritivos, 24, 20,15, 13 e 18 respectivamente. Os diagnósticos ausentes são poucos, representando 0,5\% da amostrade exames bucais (Figura 5).

\begin{tabular}{|c|c|c|c|c|c|c|c|c|c|c|c|c|c|}
\hline Ano & 1963 & 1964 & 1965 & 1966 & 1967 & 1968 & 1969 & 1970 & 1971 & 1972 & 1973 & 1974 & 1975 \\
\hline Diagnóstico & 19 & 40 & 24 & 41 & 130 & 34 & 72 & 205 & 72 & 93 & 130 & 129 & 205 \\
\hline conclusivo & $95 \%$ & $75,5 \%$ & $9,6 \%$ & $95,3 \%$ & $95,6 \%$ & $97 \%$ & $100 \%$ & $98 \%$ & $92,3 \%$ & $90,3 \%$ & $100 \%$ & $99,2 \%$ & $97 \%$ \\
\hline $\begin{array}{l}\text { Diagnóstico } \\
\text { descritivo }\end{array}$ & $\begin{array}{c}1 \\
5 \%\end{array}$ & $\begin{array}{c}11 \\
20,7 \%\end{array}$ & 0 & 0 & 0 & 0 & 0 & 0 & 0 & $\begin{array}{c}2 \\
1,9 \%\end{array}$ & 0 & $\begin{array}{c}1 \\
0,8 \%\end{array}$ & $\begin{array}{c}5 \\
2,4 \%\end{array}$ \\
\hline Ausente & 0 & 0 & 0 & 0 & $\begin{array}{c}2 \\
1,5 \%\end{array}$ & o & 0 & 0 & $\begin{array}{c}3 \\
3,8 \%\end{array}$ & 0 & 0 & o & 0 \\
\hline
\end{tabular}

\begin{tabular}{|c|c|c|c|c|c|c|c|c|c|c|c|c|c|}
\hline Ano & 1976 & 1977 & 1978 & 1979 & 1980 & 1981 & 1982 & 1983 & 1984 & 1985 & 1986 & 1987 & 1988 \\
\hline \multirow{2}{*}{$\begin{array}{l}\text { Diagnóstico } \\
\text { conclusivo }\end{array}$} & 209 & 239 & 212 & 168 & 277 & 253 & 276 & 266 & 257 & 284 & 275 & 349 & 278 \\
\hline & $99 \%$ & $96 \%$ & $92,6 \%$ & $97,7 \%$ & $98,6 \%$ & $98,4 \%$ & $97,5 \%$ & $98,5 \%$ & $96 \%$ & $91 \%$ & $90,7 \%$ & $95 \%$ & $92,3 \%$ \\
\hline \multirow{2}{*}{$\begin{array}{l}\text { Diagnóstico } \\
\text { descritivo }\end{array}$} & 0 & 9 & 12 & 2 & 1 & 0 & 1 & 1 & 6 & 24 & 20 & 15 & 13 \\
\hline & - & $3,6 \%$ & $5,2 \%$ & $1,2 \%$ & $1,06 \%$ & - & $0,3 \%$ & $0,4 \%$ & $2,2 \%$ & $7,7 \%$ & $6,6 \%$ & $4,0 \%$ & $4,3 \%$ \\
\hline \multirow{2}{*}{ Ausente } & 2 & 1 & 1 & 1 & 1 & 3 & 1 & 2 & 4 & 4 & 1 & 3 & 6 \\
\hline & $0,9 \%$ & $0,4 \%$ & $0,4 \%$ & $0,6 \%$ & $0,4 \%$ & $1,2 \%$ & $0,3 \%$ & $0,7 \%$ & $1,5 \%$ & $1,3 \%$ & $0,3 \%$ & $0,8 \%$ & $1,9 \%$ \\
\hline
\end{tabular}

\begin{tabular}{|c|c|c|c|c|c|c|c|c|c|c|c|c|c|}
\hline Ano & 1989 & 1990 & 1991 & 1992 & 1993 & 1994 & 1995 & 1996 & 1997 & 1998 & 1999 & 2000 & Total \\
\hline \multirow{2}{*}{$\begin{array}{l}\text { Diagnóstico } \\
\text { conclusivo }\end{array}$} & 395 & 267 & 226 & 331 & 332 & 375 & 511 & 593 & 735 & 973 & 1152 & 1229 & 11656 \\
\hline & $95,9 \%$ & $96 \%$ & $97,4 \%$ & $96,2 \%$ & $98,5 \%$ & $98,9 \%$ & $98 \%$ & $99 \%$ & $99 \%$ & $97,7 \%$ & $99,3 \%$ & $99 \%$ & $97,2 \%$ \\
\hline \multirow{2}{*}{$\begin{array}{c}\text { Diagnóstico } \\
\text { descritivo }\end{array}$} & 7 & 9 & 3 & 6 & 4 & 3 & 9 & 4 & 2 & 18 & 3 & 8 & 199 \\
\hline & $1,7 \%$ & 3,25 & $1,3 \%$ & $1,7 \%$ & $1,2 \%$ & $0,85 \%$ & $1,7 \%$ & $0,66 \%$ & $0,3 \%$ & $1,8 \%$ & $0,3 \%$ & $0,6 \%$ & $1,6 \%$ \\
\hline \multirow{2}{*}{ Ausente } & 4 & 0 & 2 & 4 & 0 & 1 & 0 & 2 & 4 & 2 & 3 & 0 & 57 \\
\hline & $1 \%$ & - & $0,9 \%$ & $1,2 \%$ & - & $0,3 \%$ & - & $0,3 \%$ & $0,5 \%$ & $0,2 \%$ & $0,25 \%$ & 0 & $0,5 \%$ \\
\hline
\end{tabular}

FIGURA 5 . Classificação dos diagnósticos efetuados de acordo com a sua forma de apresentação a cada ano do Serviço de Anatomia Patológic a da $\mathcal{F O B} / \mathcal{Z} S \mathcal{P}$ 
5.6 Da condizifilidade diagnóstic a com a nomenclatura atual a cada ano de atividade.

De 1963 a 1986 se observa um predominio de diagnósticos não condizentes com a nomenclatura utilizada atualmente. A partir de 1987 ocorre uma inversão brusca e intensa na proporção diagnóstico condizente/não condizente, representando os condizentes $88,8 \%$ dos diagnósticos efetuados. Com exceção de 1999 onde temos um diagnóstico não condizente, os anos de 1994 a 2000 apresentam todos diagnósticos condizentes (Figura 6).

\begin{tabular}{|c|c|c|c|c|c|c|c|c|c|c|c|c|c|}
\hline $\mathcal{A}$ no & 1963 & 1964 & 1965 & 1966 & 1967 & 1968 & 1969 & 1970 & 1971 & 1972 & 1973 & 1974 & 1975 \\
\hline \multirow{2}{*}{$\begin{array}{l}\text { Diagnóstico } \\
\text { condizente }\end{array}$} & 7 & 3 & 2 & 13 & 19 & 12 & 23 & 46 & 24 & 27 & 53 & 44 & 82 \\
\hline & $35 \%$ & $5,6 \%$ & $8 \%$ & $30,2 \%$ & $14 \%$ & $34,3 \%$ & $31,9 \%$ & $22 \%$ & $30,8 \%$ & $26,2 \%$ & $40,8 \%$ & $33,8 \%$ & $38,9 \%$ \\
\hline \multirow{2}{*}{$\begin{array}{l}\text { Diagnóstico } \\
\text { não } \\
\text { condizente }\end{array}$} & 12 & 37 & 22 & 28 & 111 & 22 & 49 & 159 & 48 & 66 & 77 & 85 & 123 \\
\hline & $60 \%$ & $69,8 \%$ & $88 \%$ & $65 \%$ & $83 \%$ & $62,8 \%$ & $68 \%$ & $76 \%$ & $61,5 \%$ & $64 \%$ & $59,2 \%$ & $65,4 \%$ & $58,3 \%$ \\
\hline
\end{tabular}

\begin{tabular}{|c|c|c|c|c|c|c|c|c|c|c|c|c|c|}
\hline Ano & 1976 & 1977 & 1978 & 1979 & 1980 & 1981 & 1982 & 1983 & 1984 & 1985 & 1986 & 1987 & 1988 \\
\hline \multirow{2}{*}{$\begin{array}{l}\text { Diagnóstico } \\
\text { condizente }\end{array}$} & 73 & 103 & 70 & 64 & 95 & 87 & 87 & 98 & 75 & 86 & 82 & 326 & 251 \\
\hline & $34,6 \%$ & $41,4 \%$ & $30,6 \%$ & $37,2 \%$ & $34 \%$ & $33,8 \%$ & $30,7 \%$ & $36,3 \%$ & $28 \%$ & $27,6 \%$ & $27 \%$ & $88,8 \%$ & $83,4 \%$ \\
\hline \multirow{2}{*}{$\begin{array}{c}\text { Diagnóstico } \\
\text { não } \\
\text { condizente }\end{array}$} & 136 & 136 & 142 & 104 & 181 & 166 & 189 & 168 & 182 & 198 & 193 & 23 & 27 \\
\hline & $64,4 \%$ & $54,6 \%$ & $62 \%$ & $60,5 \%$ & $64,4 \%$ & $64,6 \%$ & $66,8 \%$ & $62,2 \%$ & $67,9 \%$ & $63,5 \%$ & $63,7 \%$ & $6,3 \%$ & $9 \%$ \\
\hline
\end{tabular}

\begin{tabular}{|c|c|c|c|c|c|c|c|c|c|c|c|c|c|}
\hline Ano & 1989 & 1990 & 1991 & 1992 & 1993 & 1994 & 1995 & 1996 & 1997 & 1998 & 1999 & 2000 & Total \\
\hline $\begin{array}{c}\text { Diagnóstico } \\
\text { condizente }\end{array}$ & 376 & 254 & 224 & 321 & 331 & 375 & 511 & 593 & 735 & 973 & 1151 & 1229 & 8925 \\
\cline { 2 - 35 } & $91,3 \%$ & $91,4 \%$ & $96,5 \%$ & $93,3 \%$ & $98,2 \%$ & $98,9 \%$ & $98 \%$ & $99 \%$ & $99 \%$ & $97,7 \%$ & $99,2 \%$ & $99 \%$ & $74,4 \%$ \\
\hline $\begin{array}{c}\text { Diagnóstico } \\
\text { não } \\
\text { condizente }\end{array}$ & 19 & 13 & 2 & 10 & 1 & 0 & 0 & 0 & 0 & 0 & 1 & 0 & 2730 \\
\cline { 2 - 17 } & $4,6 \%$ & $0,9 \%$ & $2,9 \%$ & $0,3 \%$ & - & - & - & - & - & $0,08 \%$ & - & $22,8 \%$ \\
\hline
\end{tabular}

FIGURA 6 - Classificação dos diagnósticos efetuados quanto a sua condizibilidade com a nomenclatura atual, a cada ano do Serviço de Anatomia Patológica da FOB $/$ US $\mathcal{P}$ 
5.7 Dos diagnósticos revistos quanto a condizibilidade com a nomenclatura atual de todos os anos de atividade

Entre as lesões com atualização da nomenclatura se destaca a hiperplasia fibrosa inflamatória com várias sinonimias resgatadas dos arquivos de laudos $16,3 \%$ da amostragem total de exames bucais e $35 \%$ das lesões com alteração da nomenclatura). Outras lesões como o cisto periodontal apical, o granuloma periapical, e a doença periodontal também apresentam variação expressiva da nomenclatura

7A

\begin{tabular}{|c|c|c|}
\hline Diagnóstico & Quantidade & $\%$ \\
\hline \multicolumn{3}{|c|}{ Hiperplasia Fibrosa Inflamatória } \\
\hline Hiperplasia fibroe pite lial inflamatória & 456 & \\
\hline Hipe r plasia conjuntivo e pite lial inflamatória & 90 & \\
\hline Hipe rplasia fibrosa & 20 & \\
\hline Hipe rplasia e pite lial & 42 & \\
\hline Hiperplasia fibrosa polipóide & 17 & \\
\hline Epulide fibrosa & 20 & \\
\hline Epulide fissurado & 5 & \\
\hline Hipertrofia conjuntivo e pite lial & 11 & \\
\hline Fibroma de irritação & 4 & \\
\hline Fibroma mole & 1 & \\
\hline Pólipo fibromatoso & 5 & \\
\hline Hipe rplasia e pitélio conjuntivo & 2 & \\
\hline Fibroma polipóide & 1 & \\
\hline Hipe r plasia fibroe pite lial nodular & 4 & \\
\hline Épulis fíroso & 7 & \\
\hline Hiperplasia fibrosa re acional & 2 & \\
\hline Hiperplasiafibroangiomatóide & 11 & \\
\hline Epulide fibroangiomatóide & 1 & \\
\hline Hipe rplasia inflamatória da mucosa & 3 & \\
\hline Hipe r plasia fibrosa te langectásica & 1 & \\
\hline Hiperplasia fibrótica & 4 & \\
\hline Hipe rplasia fibrosa mixomatóide & 1 & \\
\hline Epulide mixomatóide & 1 & \\
\hline Processo inflamatório crônico hipe rplásico & 2 & \\
\hline Pólipo fib roe pite lial & 11 & \\
\hline Mucosa fiperplásica & 23 & \\
\hline Inflamação crônica prolife rativa da mucosa & 1 & \\
\hline Hiper plasia inflamatória fibrosa do córion & 1 & \\
\hline Hipe rplasia fibrosa com fialinização & 1 & \\
\hline Reação fibrosa inflamatória & 1 & \\
\hline Hipe r plasia conjuntivo inflamatória & 1 & \\
\hline Nódulo fibroso & 1 & \\
\hline \multirow{2}{*}{ Subtotal } & \multirow{2}{*}{751} & $6,3 \% *$ \\
\hline & & $35 \% *$ \\
\hline
\end{tabular}

* percentuale m re lação ao totalde exames bucais

**percentual em relação ao total de diagnósticos não condizentes com a nomenclatura atual ou revis tos

FIGURA $7 \mathcal{A}$ - Distribuição dos diagnósticos revistos de Hiperplasia Fibrosa Inflamatória quanto a sua condizibilidade com a nomenclatura atual, de todos os anos do Serviço de Anatomia Patológica da $\mathcal{F O B} / \mathcal{U S P}$ 
$7 \mathcal{B}$

\begin{tabular}{|c|c|c|}
\hline Diagnóstico & Quantidade & \\
\hline \multicolumn{3}{|c|}{ Hipe rplasia Papilar Inflamatória } \\
\hline $\begin{array}{l}\text { Hipe r plasia papilomatos a inflamatória } \\
\text { Hipe rplasia fibrosante do palato } \\
\text { Hipe rplasia fibros a do palato } \\
\text { Hipe rplasia conjuntivo e pite lial do palato }\end{array}$ & $\begin{array}{l}1 \\
1 \\
1 \\
1\end{array}$ & \\
\hline \multirow{2}{*}{ Subtotal } & \multirow{2}{*}{4} & $0,03 \% *$ \\
\hline & & $0,2 \% * *$ \\
\hline \multicolumn{3}{|c|}{ Queilite Actínica } \\
\hline Inflamação crônica ulce rada do lábio & 1 & \\
\hline \multirow{2}{*}{ r } & \multirow{2}{*}{1} & $0,008 \% *$ \\
\hline & & $0,05 \% * *$ \\
\hline \multicolumn{3}{|c|}{ Papiloma } \\
\hline $\begin{array}{l}\text { Fibroma papiloma } \\
\text { Papiloma polipóide } \\
\text { Papiloma fibroe pite lial } \\
\text { Hiper plasia fibroe pite liomatosa } \\
\text { Hipe rplasia papilomatosa } \\
\text { Papiloma ple tiforme } \\
\text { Fibropapiloma }\end{array}$ & $\begin{array}{l}5 \\
1 \\
2 \\
1 \\
1 \\
1 \\
3\end{array}$ & \\
\hline \multirow{2}{*}{ Subtotal } & \multirow{2}{*}{14} & $0,12 \% *$ \\
\hline & & $0,65 \% * *$ \\
\hline \multicolumn{3}{|c|}{ Fibrose Cicatricial } \\
\hline $\begin{array}{l}\text { Hiper plasia pós-inflamatória pe riapical } \\
\text { Tecido conjuntivo ne oformado } \\
\text { Tecido conjuntivo fibrosado } \\
\text { Fibrose periapical } \\
\text { Tecido de reparação } \\
\text { Reparação cicatricial } \\
\text { Reparação alve olar } \\
\text { Reparação fibroalve olar } \\
\mathcal{T} \text { cecido cicatricial } \\
\mathcal{H} \text { iperplasia fibrosa cicatricial } \\
\mathcal{T} e \text { cido fibroso }\end{array}$ & $\begin{array}{l}4 \\
1 \\
1 \\
2 \\
1 \\
3 \\
1 \\
1 \\
1 \\
1 \\
1\end{array}$ & \\
\hline \multirow{2}{*}{ Subtotal } & \multirow{2}{*}{17} & $0,14 \% *$ \\
\hline & & $0,8 \% * *$ \\
\hline
\end{tabular}

* percentuale m re lação ao totalde exames bucais

** percentual e m relação ao total de diagnósticos não condizentes com a nomenclatura atualou revistos

FIGURA $7 \mathcal{B}$ - Distribuição dos diagnósticos revistos de Hiperplasia Papilar Inflamatória, Queilite Actínica, Papiloma e Fibrose Cicatricial quanto a sua condizibilidade com a nomenclatura atual, de todos os anos do Serviço de Anatomia Patológica da FOB/ULP $P$ 
$7 C$

\begin{tabular}{|c|c|c|}
\hline Diagnóstico & Quantidade & $\%$ \\
\hline \multicolumn{3}{|c|}{ Granuloma Piogênico } \\
\hline $\begin{array}{l}\text { Hipe rlasia fibroendote lial da ge ngiva } \\
\text { Hipe r plasia fibroangiomatóide } \\
\text { Hipe rplasia fibroangiob lástica } \\
\text { Gengivite crônica te langectásica } \\
\text { Tecido de granulação re parador } \\
\text { Inflamaça âo crônica prolife rativa telangectásica } \\
\text { Tecido de granulação com intenso componente inflamatório } \\
\text { Granuloma gravídico }\end{array}$ & $\begin{array}{l}1 \\
1 \\
1 \\
4 \\
1 \\
3 \\
1 \\
1\end{array}$ & \\
\hline \multirow{2}{*}{ Subtotal } & \multirow{2}{*}{13} & $0,1 \% *$ \\
\hline & & $0,6 \% * *$ \\
\hline
\end{tabular}

Fibroma Cementoossificante

Fibroma cementificante

$\mathcal{F i b r o m a}$ ossificante

Fibroma osteogênico ossificante

Epulis ossificante

Epulide fibroangioblástic a com me taplasia óssea

Epulide fibrosa ossificante

Fibroosteoma

Epulide Fibroangiomatóide

\begin{tabular}{|l|l|l|} 
& & \\
\hline \multirow{2}{*}{ subtotal } & 25 & $0,2 \% *$ \\
\cline { 2 - 3 } & & $1,2 \% * *$ \\
\hline
\end{tabular}

Carcinoma Espinocelular

\begin{tabular}{|c|c|c|}
\hline $\begin{array}{l}\text { Carcinoma planoce lular } \\
\text { Carcinoma e pidermóide }\end{array}$ & $\begin{array}{c}13 \\
2\end{array}$ & \\
\hline \multirow{2}{*}{ Subtotal } & \multirow{2}{*}{15} & $0,12 \% *$ \\
\hline & & $0,7 \% * *$ \\
\hline
\end{tabular}

Cisto por Extravasamento Mucoso

\begin{tabular}{|l|c|c|}
\hline $\begin{array}{l}\text { Mucocele } \\
\text { Rânula }\end{array}$ & $\begin{array}{c}95 \\
3\end{array}$ & \\
\hline \multirow{2}{*}{ Subtotal } & 98 & $0,82 \% *$ \\
\cline { 2 - 3 } & & $4,6 \% * *$ \\
\hline
\end{tabular}

* percentualem re lação ao totalde exames bucais

**percentual em relação ao total de diagnósticos não condizentes com a nomenclatura atual ou revistos

FIGURA 7C - Distribuição dos diagnósticos revistos de Granuloma Piogênico, Fibroma Cementoossificante, Carcinoma Espinocelular e Cisto por Extravasamento Mucoso quanto a sua condizibilidade com a nomenclatura atual, de todos os anos do Serviço de Anatomia Patológic a da FOB/USP 
$7 \mathcal{D}$

\begin{tabular}{|c|c|c|}
\hline Diagnóstico & Quantidade & $\%$ \\
\hline \multicolumn{3}{|c|}{ Cisto Pe riodontal Apical } \\
\hline $\begin{array}{l}\text { Cisto radicular } \\
\text { Cisto radicular odontogênico } \\
\text { Pe riodontite apicalcrônica } \\
\text { Periodontite apical cística } \\
\text { Granuloma epiteliado/ epite lial } \\
\text { Processo inflamatório crônico proliferativo } \\
\text { Inflamação crônica proliferativa periapical } \\
\text { Processo inflamatório crônico } \\
\text { Cisto mandibular } \\
\text { Cisto com intenso infiltrado inflamatório na me mbrana } \\
\text { Cisto infectado/ com inflamação crônica } \\
\text { Lesão cística } \\
\text { Cisto odontogênico } \\
\text { Cisto periodontal } \\
\text { Cisto }\end{array}$ & $\begin{array}{l}118 \\
8 \\
10 \\
8 \\
57 \\
38 \\
5 \\
2 \\
1 \\
1 \\
3 \\
30 \\
45 \\
2 \\
6\end{array}$ & \\
\hline Subtotal & 334 & $\begin{array}{c}2,8 \% * \\
15,6 \% * *\end{array}$ \\
\hline
\end{tabular}

Doença Periodontal Inflamatória

Gengivite crônica

Processo inflamatório crônico e m gengiva

Gengivite crônic a fiper plásica

Periodontite

Mucosagengival inflamada

Gengiva inflamada crônica simples

Doença periodontal inflamatória crônica

Processo inflamatório subagudo

Inflamação crônic a e e de ma da gengiva

Mucosagengivalcom inflamação aguda

Gengivite angiomatóide

Gengivite ine specifica

\begin{tabular}{|l|c|} 
& 1 \\
\hline Subtotal & $104 \quad 0,9 \% *$ \\
\cline { 2 - 3 } & $4,8 \% * *$ \\
\hline
\end{tabular}

* percentual em re lação ao totalde exames bucais

** percentual em relação ao total de diagnósticos não condizentes com a nomenclatura atual ou revis tos

FIGURA $7 \mathcal{D}$ - Distribuição dos diagnósticos revistos de Cisto Periodontal Apical e Doença Pe riodontal quanto a sua condizibilidade com a nomenclatura atual, de todos os anos do Serviço de Anatomia Patológica da $\mathcal{F O B} / \mathcal{U S P}$ 
$7 \mathcal{E}$

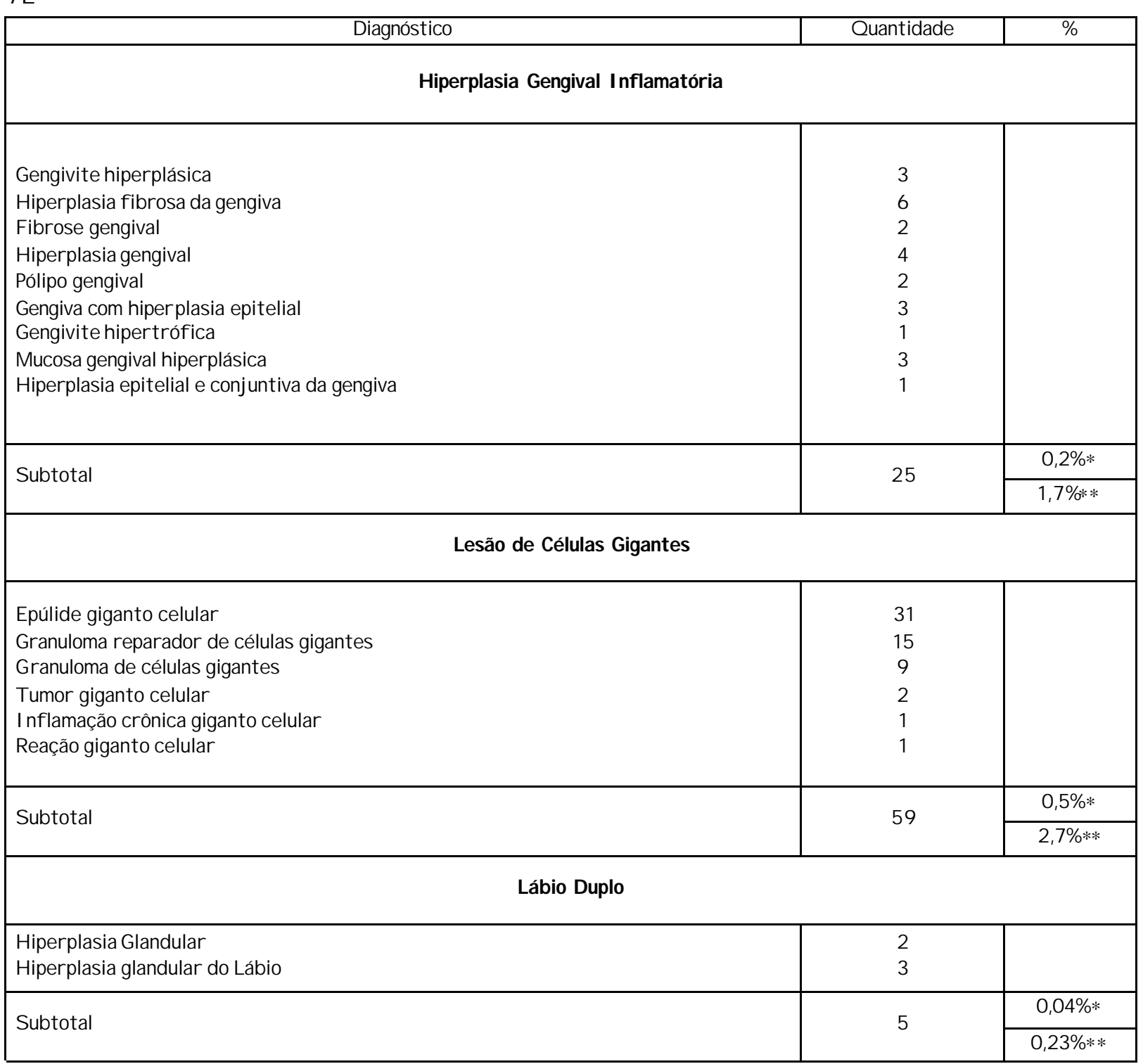

* percentual em re lação ao total de exames bucais

** percentual em relação ao total de diagnósticos não condizentes com a nomenclatura atualou revis tos

FIGURA 7E - Distribuição dos diagnósticos revistos de Hiperplasia Gengival Inflamatória, Lesão de Células Gigantes e Lábio Duplo quanto a sua condizibilidade com a nomenclatura atual, de todos os anos do Serviço de Anatomia Patológica da FOB $/$ US $P$ 
$7 \mathcal{F}$

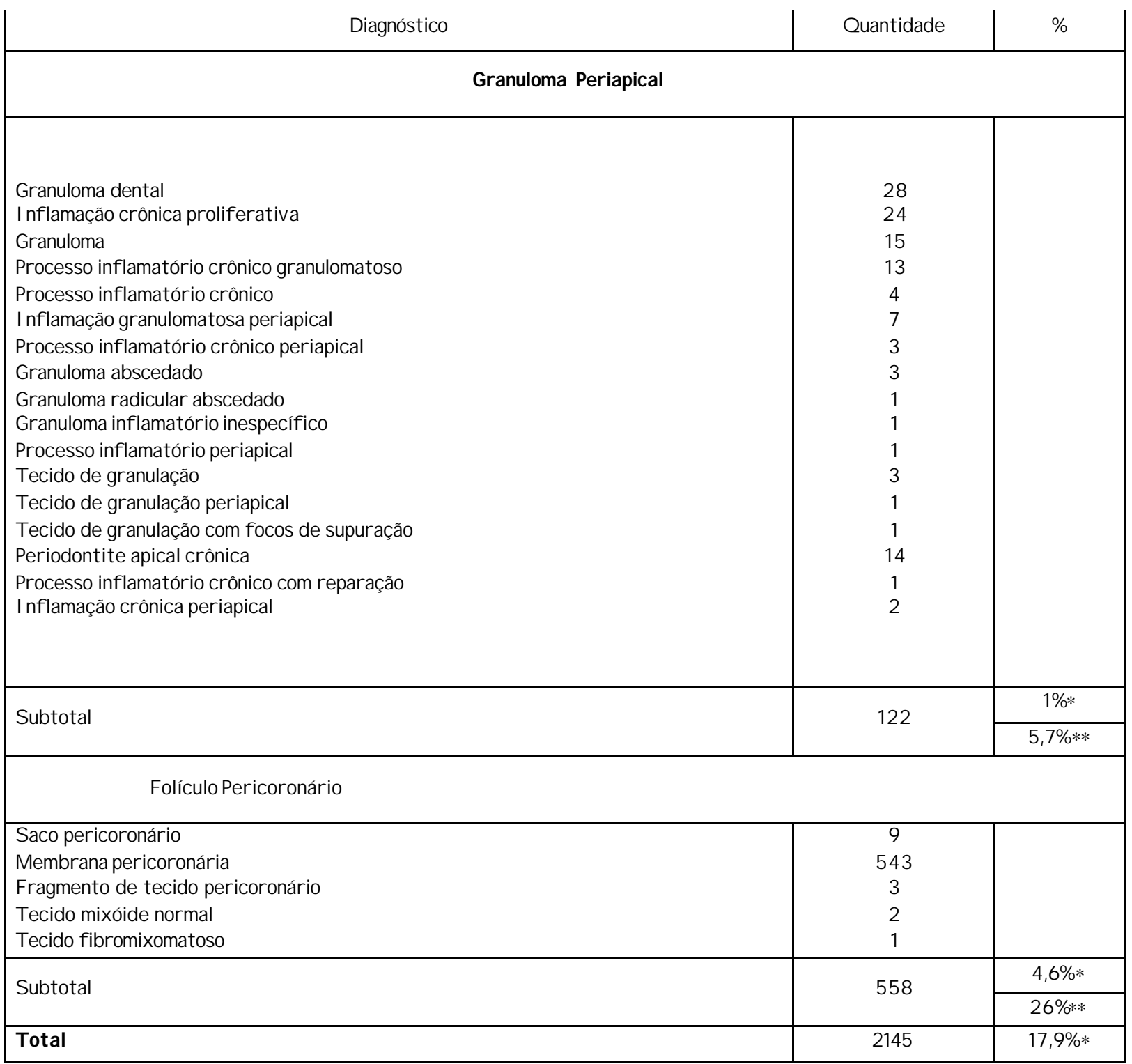

* percentual e m re lação ao total de exames bucais

** percentual em re lação ao total de diagnósticos não condizentes com a nomenclatura atualou revis tos

FIGURA $7 \mathcal{F}$ - Distribuição dos diagnósticos revistos de Granuloma Pe riapical e Folículo Pericoronário quanto a sua condizibilidade com a nomenclatura atual, de todos os anos do Serviço de Anatomia Patológica da $\mathcal{F O B} / \mathcal{U S P}$ 
5.8 Dos diagnósticos efetuados de acordo com a sua checagem frente ao confecimento atual a cada ano de atividade

Os diagnósticos revistos são mais expressivos de 1963 a 1986 . Em 1970 representam $85,6 \%$ dos diagnósticos de boca emitidos. A partir de 1987 tal fato muda bruscamente, passando a predominar os diagnósticos confirmados, chegando a $99 \%$ em 2000 (Figura 8 ).

\begin{tabular}{|c|c|c|c|c|c|c|c|c|c|c|c|c|c|}
\hline Ano & 1963 & 1964 & 1965 & 1966 & 1967 & 1968 & 1969 & 1970 & 1971 & 1972 & 1973 & 1974 & 1975 \\
\hline \multirow{2}{*}{$\begin{array}{c}\text { Diagnóstico } \\
\text { confirmado }\end{array}$} & 5 & 3 & 1 & 6 & 15 & 7 & 12 & 22 & 10 & 16 & 44 & 37 & 75 \\
\hline & $25 \%$ & $5,6 \%$ & $4 \%$ & $13,9 \%$ & $11 \%$ & $20 \%$ & $16,6 \%$ & $10,5 \%$ & $12,8 \%$ & $15,5 \%$ & $33,8 \%$ & $28,5 \%$ & $35,5 \%$ \\
\hline $\begin{array}{c}\text { Diagnóstico } \\
\text { revisto }\end{array}$ & 11 & 35 & 20 & 29 & 109 & 22 & 57 & 179 & 57 & 77 & 84 & 91 & 129 \\
\cline { 2 - 27 } & $65 \%$ & $80 \%$ & $67,4 \%$ & $80 \%$ & $62,8 \%$ & $79,2 \%$ & $85,6 \%$ & $73 \%$ & $74,7 \%$ & $64,6 \%$ & $70 \%$ & $61 \%$ \\
\hline
\end{tabular}

\begin{tabular}{|c|c|c|c|c|c|c|c|c|c|c|c|c|c|}
\hline Ano & 1976 & 1977 & 1978 & 1979 & 1980 & 1981 & 1982 & 1983 & 1984 & 1985 & 1986 & 1987 & 1988 \\
\hline \multirow{2}{*}{$\begin{array}{l}\text { Diagnóstico } \\
\text { confirmado }\end{array}$} & 67 & 88 & 60 & 56 & 85 & 77 & 78 & 77 & 63 & 71 & 75 & 314 & 245 \\
\hline & $31,7 \%$ & $35,3 \%$ & $26 \%$ & $32,5 \%$ & $30,2 \%$ & $30 \%$ & $27,6 \%$ & $28,8 \%$ & $23,5 \%$ & $22,7 \%$ & $24,7 \%$ & $85,5 \%$ & $81,4 \%$ \\
\hline \multirow{2}{*}{$\begin{array}{c}\text { Diagnóstico } \\
\text { revisto }\end{array}$} & 142 & 150 & 151 & 111 & 190 & 176 & 197 & 189 & 192 & 213 & 199 & 33 & 28 \\
\hline & $67,3 \%$ & $60,2 \%$ & $65,9 \%$ & $64,5 \%$ & $67,6 \%$ & $68,5 \%$ & $69,6 \%$ & $70 \%$ & $71,6 \%$ & $68,3 \%$ & $65,7 \%$ & $9 \%$ & $9,3 \%$ \\
\hline
\end{tabular}

\begin{tabular}{|c|c|c|c|c|c|c|c|c|c|c|c|c|c|}
\hline Ano & 1989 & 1990 & 1991 & 1992 & 1993 & 1994 & 1995 & 1996 & 1997 & 1998 & 1999 & 2000 & Total \\
\hline \multirow{2}{*}{$\begin{array}{l}\text { Diagnóstico } \\
\text { confirmado }\end{array}$} & 369 & 222 & 215 & 306 & 309 & 364 & 494 & 573 & 700 & 923 & 1086 & 1229 & 8399 \\
\hline & $89,6 \%$ & $79,8 \%$ & $92,7 \%$ & $88,9 \%$ & $91,7 \%$ & $96 \%$ & $94,8 \%$ & $95,6 \%$ & $94,5 \%$ & $92,7 \%$ & $93,6 \%$ & $99 \%$ & $70 \%$ \\
\hline \multirow{2}{*}{$\begin{array}{c}\text { Diagnóstico } \\
\text { revistos }\end{array}$} & 21 & 13 & 4 & 15 & 2 & 3 & 2 & 5 & 4 & 1 & 3 & 0 & 2944 \\
\hline & $5 \%$ & $4,7 \%$ & $1,7 \%$ & $4,4 \%$ & $0,6 \%$ & $0,8 \%$ & $0,4 \%$ & $0,8 \%$ & $0,5 \%$ & $0,1 \%$ & $0,3 \%$ & - & $24,5 \%$ \\
\hline
\end{tabular}

FIGURA 8 - Classificação dos diagnósticos efetuados de acordo com a sua checagem frente ao confecimento atual a cada ano do Serviço de Anatomia Patológic a da FOB $\mathcal{B} / \mathcal{L} P$ 
5.9 Dos diagnósticos revistos e a natureza das lesões

O granuloma periapical é a lesão com maior indice de revisão diagnóstica (34,2\% dos diagnósticos revistos). Quanto às neoplasias odontogênicas, destaca-se a revisão de ameloblastoma sólido para ameloblastoma unicístico, representando $42,8 \%$ das neoplasias odontogênicas revistas. Também são expressivos os cistos odontogênicos, predominando a revisão diagnóstica para queratocisto odontogênico (54\% dos cistos odontogênicos revistos). Salientam-se ainda duas revisões de cistos odontogênicos para ameloblastoma unicístico.

Revisões diagnósticas de neoplasias malignas para benignas, bem como sua reciproca representa em conjunto $0,016 \%$ dos exames bucais e 0,093\% dos diagnósticos revistos. Alterações diagnósticas com mudança da nature za das lesões foram escassas.

$\mathcal{N o}$ grupo das neoplasias benignas a alteração diagnóstica de hemangioma capilar para granuloma piogênico representa $0,04 \%$ dos exames bucais e 0,23\% dos diagnósticos alterados. Destaca-se ainda seu predominio no grupo das neoplasias benignas representando $83 \%$ dos casos. 


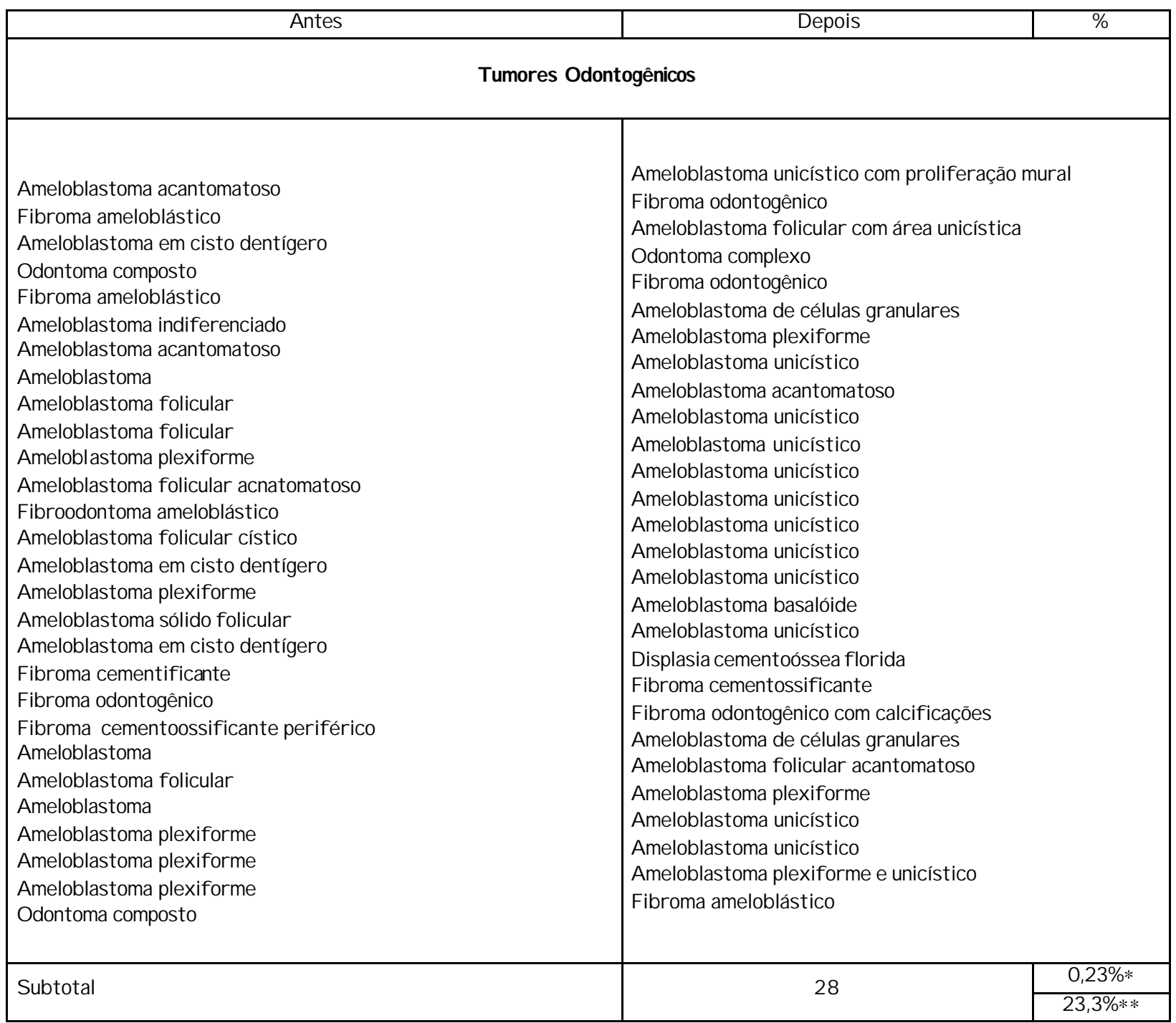

* percentual em re lação ao totalde exames bucais

** percentual e m relação ao total de diagnósticos não condizentes com o confecimento atualou revis tos

FIGURA $9 \mathcal{A}$ - Distribuição dos diagnósticos revistos de Tumores Odontogênicos de todos os anos do $\mathcal{S} e$ rviço de Anatomia Patológic a da FOB/USP 
9B

\begin{tabular}{|c|c|c|}
\hline Antes & De pois & $\%$ \\
\hline \multicolumn{3}{|c|}{ Periapicopatias inflamatórias crônicas } \\
\hline Granuloma radic ular & \multirow{41}{*}{\multicolumn{2}{|c|}{ 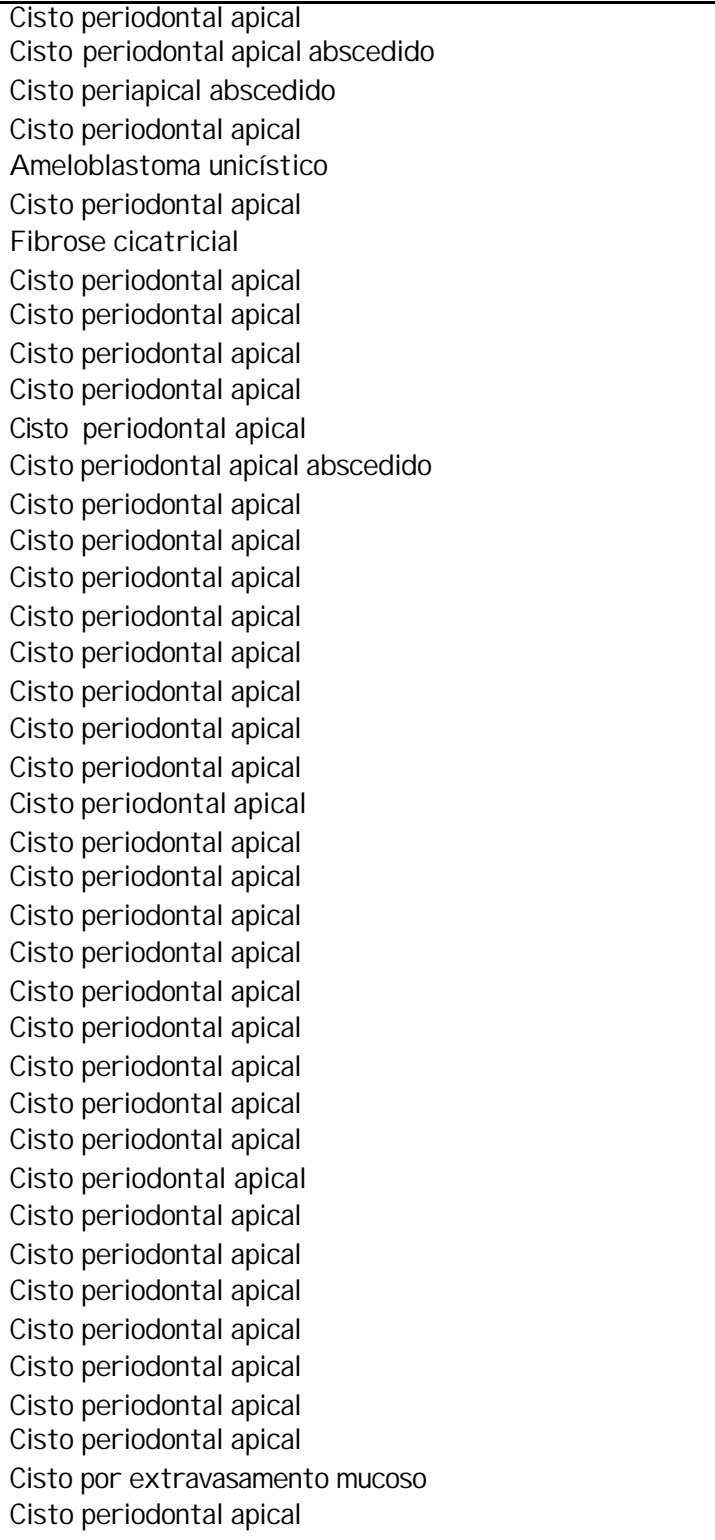 }} \\
\hline Granuloma apical e m resolução & & \\
\hline Granuloma apical com foco de supuração & & \\
\hline Granuloma periapical & & \\
\hline Cisto residual & & \\
\hline Granuloma periapical & & \\
\hline Granuloma periapical & & \\
\hline Granuloma periapical & & \\
\hline Granuloma periapical & & \\
\hline Granuloma periapical & & \\
\hline Granuloma periapical & & \\
\hline Granuloma periapical & & \\
\hline Granuloma periapical absce dado & & \\
\hline Granuloma periapical & & \\
\hline Granuloma periapical & & \\
\hline Granuloma dental & & \\
\hline Granuloma dental & & \\
\hline Granuloma periapical & & \\
\hline Granuloma periapical & & \\
\hline Granuloma periapical & & \\
\hline Granuloma periapical & & \\
\hline Granuloma periapical & & \\
\hline Granuloma periapical & & \\
\hline Granuloma dental & & \\
\hline Granuloma periapical & & \\
\hline Granuloma periapical & & \\
\hline Granuloma periapical & & \\
\hline Granuloma periapical & & \\
\hline Granuloma periapical & & \\
\hline Granuloma periapical & & \\
\hline Granuloma periapical & & \\
\hline Granuloma periapical & & \\
\hline Granuloma periapical & & \\
\hline Granuloma periapical & & \\
\hline Granuloma periapical & & \\
\hline Granuloma periapical & & \\
\hline Granuloma periapical & & \\
\hline Granuloma periapical & & \\
\hline Granuloma periapical & & \\
\hline Granuloma periapical & & \\
\hline Granuloma periapical & & \\
\hline \multirow{2}{*}{ Subtotal } & \multirow{2}{*}{41} & $0,34 \% *$ \\
\hline & & $34,2 \% * *$ \\
\hline
\end{tabular}

* percentuale m re lação ao totalde exames bucais

** percentual e m relação ao total de diagnósticos não condizentes com o confecimento atualou revis tos

FIGURA $9 \mathcal{B}$ - Distribuição dos diagnósticos revistos de Periapicopatias Inflamatórias Crônicas de todos os anos do Serviço de Anatomia Patológica da FOB $/$ ULS P 
$9 C$

\begin{tabular}{|c|c|c|}
\hline Antes & De pois & $\%$ \\
\hline \multicolumn{3}{|c|}{ Lesões Ósseas } \\
\hline $\begin{array}{l}\text { Osteoblastoma } \\
\text { Fibroma intra-ósseo } \\
\text { Fragmento de membrana cística } \\
\text { Membrana cística } \\
\text { Fragmento de membrana cística } \\
\text { Osteomielite crônica supurativa } \\
\text { Lesão cística } \\
\text { Fragmento de membrana cística }\end{array}$ & \multicolumn{2}{|l|}{$\begin{array}{l}\text { Displasiafibrosa } \\
\text { Fibroma odontogênico } \\
\text { Queratocisto odontogênico } \\
\text { Queratocisto odontogênico } \\
\text { Queratocisto odontogênico } \\
\text { Osteomielite aguda } \\
\text { Cisto periodontal apical } \\
\text { Cisto dentígero }\end{array}$} \\
\hline \multirow{2}{*}{ Subtotal } & \multirow{2}{*}{8} & $0,07 \% *$ \\
\hline & & $6,6 \% * *$ \\
\hline
\end{tabular}

Neoplasias de Glândulas Salivares

\begin{tabular}{|l|l|l|}
\hline $\begin{array}{l}\text { Ade noma pleomórfico } \\
\text { Carcinoma mucoe pidermóide } \\
\text { Carcinoma mucoe pidermóide }\end{array}$ & $\begin{array}{l}\text { Ade nocarcinoma } \\
\text { Sialome taplasia necrotizante } \\
\text { Carcinoma odontogênico de células claras }\end{array}$ \\
\hline Subtotal & & $0,025 \% *$ \\
\cline { 2 - 3 } & $2,5 \% * *$ & 3 \\
\hline
\end{tabular}

Processos Proliferativos $\mathcal{N}$ ão $\mathcal{N}$ eoplásicos

Hipe r plas ia fibros a inflamatória

Granuloma piogênico

Fibroma odontogênico

Granuloma piogê nico

Hipe r plas ia fí roe pite lial inflamatória

Hipe r plas ia fib rosa

$\mathcal{F i b r o m a ~ c e m e n t o s s ~ i f i c a n t e ~ p e r i f e ́ r i c o ~}$

Cis to por extravasamento mucoso

Cisto paradentário

Granuloma periapical

Granuloma piogênico

Fibroma cementoss ificante periférico

\begin{tabular}{|l|r|r|}
\hline Subtotal & $6,05 \% *$ & 6 \\
\cline { 2 - 3 } & & $5 \% * *$ \\
\hline
\end{tabular}

$\mathcal{N}$ eoplasias Benignas

He mangiom a capilar ulce rado He mangioma capilar ulce rado

He mangiom a capilar ulce rado

He mangiom a capilar ulce rado

He mangiom a capilar ulce rado

Papiloma

Granuloma piogênico

Granuloma piogênico

Granuloma piogênico

Granuloma piogênico

Granuloma piogênico

Granuloma piogênico

Subtotal

* percentual em re lação ao total de exames bucais

** percentual em relação ao total de diagnósticos não condizentes com o confiecimento atual ou revistos

FIGURA 9C - Distribuição dos diagnósticos revistos de Lesões Ósseas, Neoplasias de Glândulas Salivares, Processos Proliferativos $\mathcal{N}$ ão $\mathcal{N}$ eoplásicos e $\mathcal{N}$ eoplasias Benignas de todos os anos do $S$ erviço de Anatomia Patológic a da $\mathcal{F O B} / \mathcal{U S} P$ 
9D

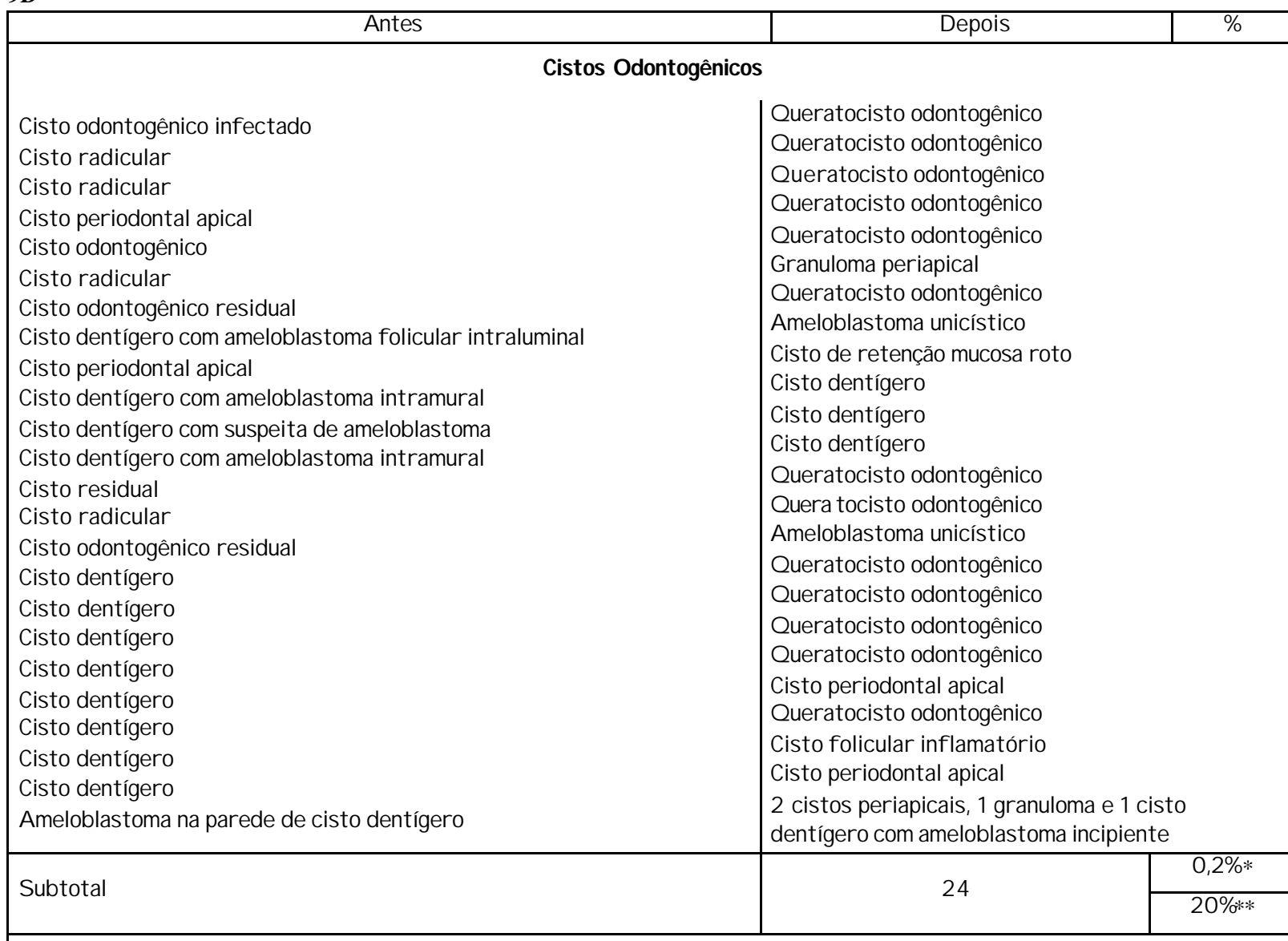

Cistos $\mathcal{N}$ ão Odontogênicos

\begin{tabular}{|c|c|c|}
\hline $\begin{array}{l}\text { Cisto por extravasamento mucoso } \\
\text { Cisto de retenção mucosa roto }\end{array}$ & \multicolumn{2}{|l|}{$\begin{array}{l}\text { Granuloma periapical } \\
\text { Cis to periodontal apical }\end{array}$} \\
\hline \multirow{2}{*}{ Subtotal } & \multirow{2}{*}{2} & $0,02 \% *$ \\
\hline & & $1,7 \% * *$ \\
\hline \multicolumn{3}{|l|}{ Neoplasias Malignas } \\
\hline Carcinoma basocelular & \multicolumn{2}{|l|}{ Carcinoma espinocelular } \\
\hline Carcinoma espinoce lular moderadamente diferenciado & \multicolumn{2}{|c|}{ Carcinoma odontogênico de células claras } \\
\hline Subtotal & 2 & $\begin{array}{l}0,02 \% * \\
1,7 \% * *\end{array}$ \\
\hline Total & 120 & $1 \% *$ \\
\hline
\end{tabular}

* percentualem re lação ao total de exames bucais

** percentual em relação ao total de diagnósticos não condizentes com o confecimento atual ou revis tos

$\mathcal{F I G U R A ~ 9 D ~ - ~ D i s t r i b u i c ̧ a ̃ o ~ d o s ~ d i a g n o ́ s t i c o s ~ r e v i s t o s ~ d e ~ C i s t o s ~ O d o n t o g e ̂ n i c o s , ~ C i s t o s ~} \mathcal{N}$ ão Odontogênicos e $\mathcal{N}$ eoplasias Malignas de todos os anos do Serviço de Anatomia Patológica da FOB/USP 
6 DIS CULS S $\tilde{A} O$ 


\section{DIS CUS S $\tilde{\mathcal{A} O}$}

\section{$6.1 \mathcal{D a}$ conce pçãa e me todologia do trabalho}

O Serviço de Anatomia Patológica da $\mathcal{F O B} / \mathcal{Z} \mathcal{S} \mathcal{P}$ vem se desenvolvendo desde 1963. Com o passar dos anos, pelas aposentadorias, a troca de gerações fez parte do seu contexto. Neste período podem ser observadas mudanças tanto na estrutura quanto na sua dinâmica. As atividades constantes de sua rotina abrangem o recebimento de peças cirúrgicas seguido do seu registro e processamento. Deste advém a emissão de um laudo contendo o diagnóstico referente ao caso. A entrega do laudo ao profissional requisitante conclui o ciclo ou processo diagnóstico do Serviço de Anatomia Patológica e deve ser no menor tempo possível ${ }^{45,47}$. Os cuidados para preservar o rigor no processamento das peças cirúrgicas, na elaboração dos laudos, na conclusão do diagnóstico, dãa credibilidade ao Serviço. Por outro lado, a organização e o estabelecimento de uma sistemática condizente com a magnitude do Serviço são essenciais ao seu desenvolvimento e manutenção.

Um aspecto importante na elaboração do diagnóstico está no contato freqüente com a literatura científica. Ela nos fornece dados para a emissão de um diagnóstico com a nomenclatura atualizada, bem 
como nos permite o confecimento de entidades clínicas novas. O ideal seria estabelecer uma relação de reciprocidade; dela extrair, mas à ela retornar por meio de novas publicações. A preocupação com a atualização das nomenclaturas das lesões, o reconfecimento de entidades clínicas novas através da revisão dos diagnósticos são aspectos fundamentais capazes de tornar o Serviço um centro de excelência em diagnósticos anatomopatológicos.

Uma entidade clínica pode ser distinta quando apresenta etiopatogenia, características clínicas, laboratoriais e imagenológicas especificas que the conferem identidade única no conjunto das doenças bucomaxilofaciais. Novas entidades clínicas advêm do aprofundamento do confecimento sobre uma de terminada doença e suas variáveis. Ainda, novos agentes etiológicos podem surgir do contexto atual, como aconteceu com a AIDS a "Sindrome da Vaca Louca" ou Encefalopatia Espongiforme Bovina.

$\mathcal{N a}$ fistória do Serviço de Anatomia Patológica da FOB/USP se destaca o ano de 1987 como o inicio na mudança de paradigmas. A forma de apresentação dos laudos aprimora-se. Estes passam a ter além do diagnóstico a descrição microscópica. A macroscopia, antes realizada por técnicos, passa a ser de responsabilidade do patologista. A atenção dispensada a nomenclatura das lesões no diagnóstico é notória com a 
emissãa de $88,8 \%$ de diagnósticos condizentes com a nomenclatura atualizada. O total de exames com diagnósticos revistos têm uma queda percentual drástica, como se nota na figura 8 . Até 1987 , representavam e m média $85 \%$ dos diagnósticos emitidos; neste ano, caem para $9 \%$ dos diagnósticos emitidos. A renovação e o amadurecimento se revelam tanto na forma de apresentação da documentação como no início da informatização do Serviço. Integram esta documentação o conjunto de laudos, lâminas e blocos referentes a cada exame. São eles os formadores do patrimônio científico do Serviço de Anatomia Patológica da $\mathcal{F O B} / \mathcal{U} \mathcal{P}$. Importante e oportuno ressaltar o mérito de todos os que de alguma forma contribuíram na sua e laboração.

O acervo da Anatomia Patológica da $\mathcal{F O B} / \mathcal{U S} \mathcal{P}$ tem um valor inestimável, seja na quantidade e diversidade das lesões, seja na raridade de algumas. A sua organização contribui tanto na geração de recursos fumanos como no aumento da produção científica. $\mathcal{A}$ esta produção incorpora-se a sua utilização por pesquisadores de outras especialidades e outras instituições.

$\mathcal{A}$ mudança na sistemática de arquivamento das lâminas precedeu ao resgate da documentação dos 37 anos do Serviço de Anatomia Patológic a da $\mathcal{F O B} / \mathcal{U} S \mathcal{P}$. As lâminas armazenadas e m arquivos de aço inadequados. Estes, constituídos por gavetas, apresentando cada 
uma nichos com espaços para acomodar duas a três lâminas juntas, comprometiam sua integridade. Sua substituição por caixas de madeira com nichos individuais e capacidade para cem lâminas protegidas foi imediata. Etiquetas contendo dados referentes ao ano e à numeração das lâminas identificam-nas. Assim, permitiu maior agilidade no seu manuse io além de auxiliar na preservação da sua integridade.

$\mathcal{N}$ o estudo dos cortes microscópicos durante a retrospectiva do Serviço surgiram várias dificuldades. Uma delas consistiu na existência de lâminas referentes aos primeiros anos com comprometimento da sua coloração. Embora algumas tivessem os respectivos blocos permitindo sua reposição, optou-se por agrupá-las como exames não passíveis de análise, como pode ser observado na figura 3. Outros problemas ocorreram como a ausência significativa de lâminas correspondentes há vários anos, como se nota na figura 3. Algumas relacionadas a teses já concluidas ainda se encontravam com seus respectivos orientadores. Outras, não houve explicação para sua ausência. A confecção de novos cortes microscópicos, permitindo a reposição dessas lâminas está sendo realizadagradativamente par a não comprometer a rotina diagnóstica.

Os blocos de parafina são essenciais na confecção de novos cortes microscópicos. No seu resgate, observou-se o armazenamento inadequado dos blocos referentes ao periodo de 1963 a 1996. Seu 
acondicionamento em sacos plásticos ocasionou a deformação da parafina, comprometendo novos cortes. A ausência de alguns explica-se pela plena utilização em Teses, Dissertações e trabalhos de Iniciação Cientifica. Dependendo da quantidade de material incluido, a confecção de colorações especiais também acarreta no seu consumo total. Dada a sua importância, cuidados devem ser impostos no seu acondicionamento, como mantê-los em ambientes climatizados, em locais que permitam sua disposição individual, obedecendo a critérios de organização rígida.

Os laudos completam a documentação analisada. Estes contêm os dados do paciente, do profissional requisitante, a descrição microscópica, após 1987 e o respectivo diagnóstico. Alguns se encontravam ausentes do arquivo, devido ao não processamento da peça cirúrgica correspondente ou mesmo, mas raramente, à inexistência de um registro, como se nota na figura 3. Outra explicação para esta ausência é o acondicionamento dos laudos referentes aos últimos anos em folhas soltas armazenadas em pastas. As intensas atividades do corpo discente e docente levam muitas vezes ao esquecimento de sua devolução. Os demais se encontravam encadernados com capa dura e separados por ano de Serviço.

Diante dessas constatações, a reestruturação de todos os arquivos tornou-se uma exigência. A ausência de um programa de 
qualificação dos recursos fumanos e a demora na integração do corpo discente às atividades do Serviço retardaram esse processo. Todas as dificuldades encontradas na busca das lâminas, blocos e laudos estãa relacionadas ao processo de amadurecimento do Serviço. A motivação,o comprometimento e a conscientização dos recursos fumanos $s \tilde{a} o$ "frutos" de um processo longo. Palestras com esse objetivo devem ser cíclicas. Nea menos importante, e talvez fundamental, tem sido a descentralização de responsabilidades. Esta, contudo, só se torna viável na medida em que todos os integrantes do Serviço estejam aptos a absorvê-la. A mobilização dos recursos fumanos requer a conscientização individual no contexto do Serviço. Um pensamento deve nortear seus integrantes: "Organizar para diminuir os erros. Inovar para não perecer".

O perfil da clientela ao longo destes anos não foi avaliado. Decidiu-se por não fazê-lo diante da ausência em vários exames de dados que identificassem o tipo de clientela, além da presença de muitas variáve is e mosso estudo. O aumento e ampliação desta clientela podem ser observados quer no recebimento de peças cirúrgicas procedentes de diversos estados quer na rotina diagnóstica com o processamento de 996 peças cirúrgicas 6ucais em 1998, como pode ser constatado na figura 2. Atendendo a esta demanda, desenvolveu-se um 
programa de computação específico. Este software permitiu agilizar a emissão de laudos reduzindo o tempo entre o recebimento das peças cirúrgicas e o seu envio ao profissional requisitante. O programa também dispõe de recursos para busca de casos por palavras chave contidas nos laudos, bem como por diagnósticos emitidos. Face às exigências atuais, este programa se encontra em processo de reformulação, mas em pleno uso.

Em nosso entendimento, o acervo do Serviço de Anatomia Patológica da $\mathcal{F O B} / \mathcal{B S} \mathcal{P}$, dado ao seu valor científico para comunidade acadêmica e ao seu valor fistórico, urge na sua reformulação. Seus arquivos dispostos em ambientes climatizados e organizados por tipos de lesões, facilitariam as 6uscas. $\mathcal{A}$ informatização generalizada e integrada permitiria uma seleção prévia do material a ser estudado pelo acesso ao banco de dados do Serviço em pouco tempo de espera. $\mathcal{A}$ criação de uma taxa simbólic a para sua utilização por outras ins tituições $e$ departamentos contribuiria para sua manutenção e renovação constante.

Em relação aos custos deve-se ressaltar o valor de cada lâmina obtida em um exame, calculado em aproximadamente sessenta reais à parte do valor administrativo e trabalfista dos recursos fumanos 
necessários para a realização dos trabalhos. Preservar e conservar significa economicamente reduzir custos a médio e longo prazo.

O acervo tem potencial para tornar-se centro de referência nacional na obtenção de amostragem para monografias, dissertações e teses. A atual realidade do Serviço de Anatomia Patológica da $\mathcal{F O B} / \mathcal{U S P}$, com uma demanda de 1314 exames de tecidos frumanos anuais, requer para implantação de novas diretrizes a contratação de mais recursos humanos qualificados, tanto na área de informática como na área laboratorial. A sua evolução abrange o desenvolvimento de um arquivo de lâminas virtual. Assim, facilitaria ainda mais o acesso ao confecimento, além de dinamizar os estudos. Em sintese, o despertar para o rápido avanço tecnológico se faz presente e necessário, antecipando-se as tendências captadas com sensibilidade e confecimento de seus integrantes.

Uma característica peculiar do Serviço de Anatomia Patológica da $\mathcal{F O B} / \mathcal{U S}$ P está na sua especificidade: a Patologia Bucal. Es ta vocação histórica e a necessidade de concentrar esforços levaram à decisão de não mais receber para análise peças cirúrgicas de animais advindas de clínicas veterinárias e fora do contexto bucal dos mesmos. Esta decisão ocorreu em 1999, e seus reflexos podem ser observados na proporção 
dos dados quanto à origem animal das peças cirúrgicas recebidas, conforme a figura 1.

$\mathcal{A}$ metodologia empregada permitiu uma imersão fistórica, funcional e técnica na estrutura do Serviço de Anatomia Patológica da $\mathcal{F O B} / \mathcal{U S P}$. O levantamento dos dados implicou no auto-confecimento do Serviço, de suas potencialidades e possibilidade de redimensionar os diagnósticos e casuístic a acumulados.

6.2 Dos aspectos históricos e organizacionais

O Serviço de Anatomia Patológica da FOB/USP teve seu início em 1963 com finalidade quase exclusiva de atender as clínicas da Faculdade. O número crescente de exames aconteceu a partir de uma conscientização maior de alunos e professores associada a uma divulgação da existência do Serviço. Esta se realizou por meio de cursos em congressos e atividades interdisciplinares exercidas pelos profissionais e pós-graduandos da disciplina de Patologia. Essa e volução está demonstrada na figura 1. Entre 1995 a 1999, houve um crescimento de Serviços prestados a veterinários que foi interrompido em 2000, em função do estabelecimento de prioridades nos objetivos, associado à aplic ação direcionada de recursos fumanos e financeiros. 
O Serviço de Anatomia Patológica da $\mathcal{F O B} / \mathcal{U} S \mathcal{P}$ é es pecializado e m patologia bucal; as peças recebidas de outra origem, quanto ao local do corpo humano, representam um potencial muito pequeno e quase sempre são peças de pele, na maioria, relacionada a doenças associadas com a mucosa bucal. A priorização de exames de peças da região bucal implica na maior profundidade do confecimento necessário para o diagnóstico preciso.

$\mathcal{N a}$ análise dos resultados, do ponto de vista numérico, predominam as peças cirúrgicas sobre os esfregaços, como pode ser observado na figura 2. A citologia esfoliativa te m o seu valor relacionado à orientação de conduta como a escolfa de área a ser biopsiada e a natureza da lesão. Os laudos emitidos a partir de esfregaços, na maioria descritivos, raramente permitem ou suportam a escolha precisa de uma terapêutica adequada e quase sempre se requer a realização de biópsia. Provavelmente em função disso, e considerando o fácil acesso cirúrgico aos tecidos bucais, os profissionais optam pelo procedimento da biópsia.

O número de casos de um Serviço de Patologia Bucal pode ser muito maior, pois não há uma cultura disseminada que envolva o seguinte preceito: "Todo tecido removido do paciente deve ser analisado microscopicamente por questões éticas, morais e legais". Ulm exemplo disso está na prevalência de certas doenças e no número de exames 
envolvidos, destacando-se: as doenças periodontais, as alterações periapicais e os tecidos pulpares e pericoronários. Esta disparidade aumenta muito mais se considerarmos os tecidos dentários mineralizados; quantas situações patológicas deixam de ser diagnosticadas nos tecidos cirurgicamente removidos e desprezados, incluindo-se: cárie dentária, fraturas dentárias, reabsorções dentárias, disgenesias dentárias, pigmentação dentária, desgaste dentário, abfração, fipercementose e outras?

Se irrestritamente todos os tecidos removidos fossem enviados para diagnóstico anatomopatológico com certeza os procedimentos odontológicos seriam melhor fundamentados e mudaria o perfil da Odontologia $\mathcal{N a c i o n a l . ~ D o ~ i n i c i o ~ d o ~ S e r v i c ̧ o ~ a o s ~ d i a s ~ a t u a i s ~ p e r c e b e - s e ~}$ nitidamente uma mudança, não só quantitativa mas qualitativa do material enviado observada na figura 4. Apesar de lento, este processo mencionado anteriormente parece estar acontecendo.

o aumento do número de casos ao analisar a figura 1 se fez principalmente a partir de 1987. No período de 1987 a 2000, houve um incremento da participação da Disciplina de Patologia em eventos científicos, orientações e publicações científicas. Também nesse período, houve atividades de pós-graduação, mestrado e doutorado, na área de Patologia Bucal. Estes dois fatores levam à maior divulgação do 
Serviço, o aumento de sua credibilidade, além de propiciar interface com potenciais usuários do Serviço de Anatomia Patológica da $\mathcal{F O B} / \mathcal{U} S$ P. O período mencionado permitiu uma maior eficiência do trinômio, conscientização, divulgação e credibilidade.

$\mathcal{A}$ manipulação dos registros, laudos, lâminas e blocos de parafina permitiu a rechecagem e a identificação de falhas, podendo agora se corrigidos otimizar o resgate de informações para o estudo e pesquisa das doenças diagnosticadas nestes 37 anos. Considerando este período de tempo e a fistória do Serviço num contexto brasileiro, as gerações atuais devem vangloriar pela integridade de todo o material processado. Esse representa um dos poucos exemplos de preservação por tão longo período. As falhas encontradas têm suas causas discutidas no item deste capitulo sobre as razões que levaram a concepção deste trabalho.

Os diagnósticos efetuados durante toda a história do Serviço de Anatomia Patológica da FOB/USP s ão caracteristicamente conclusivos, assim se observa na figura 5. Na rotina diagnóstica tem-se como orientação, sempre quando for possível, evitar diagnósticos descritivos em função de sua imprecisão e da necessidade de correlações clínicoradiográficas. Essas, muitas vezes, fogem da possibilidade da realização por parte ou envolvendo o patologista. A clientela do Serviço tem a expectativa do diagnóstico preciso e conclusivo, pois na rotina clínica 
esta representa a necessidade imediata. O diagnóstico descritivo posterga a adoção de condutas frente ao paciente, gera dúvidas e insegurança no clínico receptor e diminui a credibilidade do Serviço frente a sua clientela.

A maioria, ou melhor, a quase totalidade do material enviado se apresenta adequado para análise (figura 4). Esses resultados sugerem uma clientela treinada para obtenção, preparo e envio do material ao Serviço. Os poucos casos anuais de material não adequado quase se mpre estavam relacionados a acidentes como troca acidental do fixador, quebra das embalagens durante o envio ou ainda, pequena quantidade de mate rial para análise.

\section{$6.3 \mathcal{D a} \mathcal{N o m e n c l a t u r a}$}

$\mathcal{A}$ sinonimia quanto mais ampla pode até denotar erudição, mas nos dias de hoje gera confusão em função do excesso de informação a ser resgatada por meio de computadores, indices e bancos de dados. $\mathcal{A}$ sinonimia extensa contraria os processos de padronização, facilitadores do resgate de informação e dados. A criação dos bancos de dados e a sua ampla utilização evidenciam a necessidade da escolha de nomes coerentes para identificação das doenças. A escolha de um ou dois nomes facilita a intercomunicação e o armazenamento de 
informação. N ão se justificam 32 nomes diferentes para a hiperplasia fibrosa inflamatória; 15 nomes para cisto periodontal apical, 12 nomes para doença periodontal inflamatória e 9 para fiperplasia fibrosa gengival, encontrados nos arquivos.

\subsubsection{Hipe rplasia Fibrosa Inflamatória}

A hiperplasia representa o fibrosamento do exsudato formado após cada traumatismo na mucosa bucal. $\mathcal{A}$ repetição desse fenômeno exsudato e fibrosamento acaba promovendo um aumento volumétrico fibroso da região. Isso ocorre pela colonização desse exsudato por células fibroblásticas. Induzidas a proliferar-se na região, promovem uma adaptação estrutural à nova situação. O termo fiperplasia fibrosa inflamatória já se generalizou quanto ao uso em nosso me io e nos parece coerente com a etiopatogenia da doença.

\subsubsection{Hiperplasia Fibrosa Gengival}

$\mathcal{N}$ os casos enquadrados como hiperplasias gengivais fibrosas, alguns podem ser descritos como hiperplasia fírosa inflamatória de mucosa 6ucal. As hiperplasias gengivais fibrosas constituem quadros clínicos característicos enquadrados como fiperplasias gengivais fibrosas 
medicamentosas, familiares ou hereditárias e inflamatórias. Nos laudos e mitidos, essas distinções não se apresentam contempladas entre os 25 casos representados na figura $7 \mathcal{E}$.

\subsubsection{Les ão de Células Gigantes}

$\mathcal{A}$ nomenclatura, além da coerência com as suas estruturas constituintes, deve, na medida do possível, favorecer a compreensão implícita da sua etiopatogenia. Termos como épulis, tumor, reação, pólipo, nódulo e lesão cística são genéricos e representam formas de manifestação de várias doenças. Um exemplo se refere à lesão de células gigantes periférica ou central. Quando se refere a tumor de células gigantes há diversas lesões que se manifestam como tumefações constituídas por células gigantes, como inflamações crônicas granulomatosas, áreas de reabsorção dentária, lesões ósseas do hiperparatireoidismo, "fíroma de células gigantes" e outras. O termo lesão de células gigantes periférica ou central identifica melhor a doença, apesar do termo "lesão" ser também muito amplo e genérico. Pelo menos não há lesão ne oplásica com este nome afetando outras áreas como o "tumor de células gigantes" e ocorrendo em outros ossos do esquele to como les ão distinta. $\mathcal{N a}$ figura $7 \mathcal{E}$ podem ser observadas as diversas nomenclaturas utilizadas para esta lesão. 


\subsubsection{Lábio Duplo}

Em muitos casos, a simplicidade do nome da doença pode levar o patologista ou o clínico ao uso de nomes mais elaborados, mas não tão precisos ou indicativos. Um exemplo disso está no quadro clínico confecido como lábio duplo. Se o patologista identificar fiperplasia das glândulas labiais superiores, quando o clínico identificou na ficha de envio o quadro de lábio duplo, é mais simples e prático colocar no item diagnóstico final a expressão "Compatível com $(C / C)$ lábio duplo". O diagnóstico final de fiperplasia glandular poderá não refletir necessariamente lábio duplo no paciente, mas se o clínico o identificou, parece-nos lógica esta prática. Essa nomenclatura genéric a foi utilizada em 5 casos de nossos arquivos mostrados na figura $7 \mathcal{E}$ e não permite. nos saber se o diagnóstico clínico se confirmou.

\subsubsection{Doença Periodontal Inflamatória}

$\mathcal{A}$ simplicidade ajuda na intercomunicação e no resgate de informações em bancos de dados. Por outro lado, a simplificação não criteriosa pode implicar em generalização. O termo doença periodontal inflamatória abarca um número muito grande de situações clínicas. Nos casos de doença periodontal inflamatória crônica, se faz importante 
classificá-la nas quatro fases estabelecidas por PAGE; SCHROEDER $(1976)^{37}$ : inicial, precoce, estabelecida e avançada. Os termos gengivite e periodontite podem ser precisamente utilizados e identificados mas requerem para tal o exame clínico do paciente pois os critérios diferenciadores envolvem a presença de bols a periodontal inflamatória e perda óssea na crista alveolar, quase sempre não detectáveis microscopicamente.

Atualmente os laudos são emitidos classificando-se a doença periodontal inflamatória crônica de acordo com essas fases. Levam em consideração a etiopatogenia da doença e seus aspectos microscópicos. $\mathcal{N a}$ figura $7 \mathcal{D}$ observam-se 104 casos de doença periodontal inflamatória e as diversas nôminas utilizadas, quase todas genéricas e imprecisas.

Outras periodontopatias inflamatórias como o abscesso gengival e periodontal, a $\mathcal{G U N}(\mathcal{A}$ e as periodontites agressivas, raramente of erecem dificuldades quanto à nomenclatura na determinação do diagnóstico final nos laudos microscópicos, mas em geral não se obtém fragmentos para o envio de peças cirúrgicas e posterior diagnóstico microscópico. 


\subsubsection{Granuloma Piogênico}

Uma nomenclatura curiosa e amplamente utilizada refere-se ao granuloma piogênico. A lesão não é um granuloma e tão pouco formadora de pus. Nos 13 casos de granuloma piogênico com outras nomenclaturas, observa-se uma tentativa predominante na busca de um termo mais fiel as estruturas da lesão. O granuloma piogênico representa uma formação reacional e exuberante de tecido de granulação frente a uma agressãa de baixa intensidade e longa duração.

$\mathcal{A N N E R O T H}$ S IGURDS $O \mathcal{N}^{2}$ acreditam que o termo fiperplasia angiomatóide seria mais apropiado; entre os nomes encontrados alguns utilizaram o termo fiperplasia fibroangioblástica ou fibroangiomatóide; $e$ ainda tecido de granulação reparador como pode ser observado na figura 7C. Quando em mulheres grávidas o granuloma piogênico também foi denominado e m laudo como granuloma ou tumor gravídico. Apesar de incorreto e aparentemente absurdo, em laudos fistopatológicos deixarse de usar o termo granuloma piogênico, optando por outra nomenclatura mais fiel a sua composição estrutural, do ponto de vista prático trará menos benefícios e gerará mais confusão do que esclarecimento, infelizmente. O uso do termo granuloma piogênico é ge ne ralizado universalmente. 
6.3.7 Fibroma Cementoos sificante

$\mathcal{A}$ evolução do confecimento e sua sedimentação ao longo do tempo, quase que obrigatoriamente, modifica determinadas nomenclaturas. Muitas lesões periféricas e centrais dos maxilares apresentam formação de tecido mineralizado, especialmente os fibromas. A formação de tecido mineralizado pelas células neoplásicas ora era atribuída como de natureza cementária, ora de natureza óssea. $\mathcal{N a}$ última década generalizou-se e tornou-se consenso o uso do termo "cementoossificante" para esse fenômeno, e assim identificar lesões que apresentam-no. Nõa fá tecnologia para identificar esta natureza cementária ou óssea nas lesões fibrosas dos maxilares. Em 25 casos, observados na figura 7C, o fibroma cementoossificante foi adje tivado como ossificante, cementificante, os teogênico e até me taplásico.

6.3.8 Cis to por Extravasame nto Mucoso

Os termos mucocele e rânula indicam fenômenos de retenção de muco salivar nos tecidos da mucosa bucal. Esse fenômeno pode acontecer em ductos obstruídos por sialolitos ou por processos cicatriciais pós-traumáticos. Na evolução deste acúmulo, e se identificado neste momento, microscopicamente veremos uma cavidade cística revestida por epitélio derivado do ducto. Nesse caso o 
diagnóstico final a ser dado será de cisto por retenção mucosa e, entre parênteses, se utilizará o termo mucocele ou rânula conforme a ide ntific ação do clínico na ficha de e nvio.

O crescimento do cisto por retenção mucosa pode levar ao rompimento do epitélio com extravasamento do muco para o tecido conjuntivo periférico. Esse fenômeno também pode se dar por traumatismo da mucosa bucal, seguido de ruptura do ducto. Nas duas situações mencionadas, o tecido conjuntivo delimitará esse acúmulo de muco constituindo uma faixa de tecido de granulação periférica. Este quadro microscopicamente é identificado como cisto por extravasamento mucoso. Clinicamente não se pode distinguir o cisto por retenção mucosa do cisto por extravasamento mucoso, recebendo ambos a nomenclatura de mucocele ou rânula.

Em 98 casos visualizados na figura $7 \mathcal{C}$, esse de talfamento não foi observado provavelmente porque não muda a forma de tratamento e prognóstico desses casos clínicos e não houve preocupação quanto a etiopatogenia da doença. O de talhamento no diagnóstico pode reforçar a fistória clínica do caso, confirmar um relato na anamnese e associar a doença com sua verdade ira causa. 
Algumas questões terminológicas observadas são sutilezas que podem influenciar e muito no resgate de informações dos arquivos para fins de estudo e pesquisa.

6.3.9 Folículo Pe ricoronário

O termo folículo pode ser utilizado em várias áreas do confecimento para identificar estruturas remanescentes que já formaram o seu "fruto" ou estrutura para o qual foi estabelecido. Em 543 casos, o diagnóstico de folículo pericoronário foi dado como membrana pericoronária e em 9 outros casos de saco pericoronário. Os termos membrana e saco não refletem precisamente o órgão reduzido do esmalte que persiste sobre a coroa dos dentes formados até a sua erupção; o termo folículo pericoronário além de mais elegante e preciso, é coerente com todo o processo biológico envolvido tanto na odontogênese quanto na erupção dentária.

Um exemplo de que sutilezas podem influenciar o estudo e a pesquisa, pode ser dado por este singelo exemplo. Se no computador nãa se utilizar à expressão membrana pericoronária um termo nãa generalizado na literatura universal, 543 casos não teriam sido resgatados. Um número altamente significante como se vê na figura $7 \mathcal{F}$. 


\subsubsection{Carcinoma Espinoce Lular}

Em alguns casos os termos utilizados têm origem nos costumes pessoais ou vícios de linguagem do patologista. Essa situação dificulta a padronização do sistema de resgate das informações e dados. Um exemplo está no uso do termo carcinoma planocelular para os carcinomas espinocelulares como ocorreu em 13 casos observados na figura 7 C.

Outra situação curiosa quanto à nomenclatura está na especialidade em cujo contexto se faz o diagnóstico fistopatológico. Na dermatopatologia com muita freqüência usa-se o termo carcinoma e pidermóide, encontrado em dois casos dos nossos arquivos mostrados na figura 7C; na patologia bucal, o termo mais utilizado continua sendo carcinoma espinocelular. A expressão espinocelular relaciona-se com a semelhança das células cancerosas com as células da camada espinfiosa dos epitélios estratificados e não com sua origem estrutural; a terminação "óide" significa "semelhante a" e nos carcinomas apesar de ampla formação de queratina, a sua desorganização não imita a e piderme. 


\subsubsection{Fibrose Cicatricial}

Os diagnósticos descritivos podem em alguns casos substituir de forma mais precisa termos mais curtos ou taxativos. De acordo com a área ou local envolvido, o tecido conjuntivo ao reparar-se gera alte rações morfológicas e inconvenientes que requer cirurgia corretiva. A análise microscópica das peças cirúrgicas assim obtidas pode ser identificada com o termo "fibrose cicatricial", ou ser complementada esta expressão, com adjetivos indicativo de sua localização ou do processo existente anterior a reparação.

Em 17 casos, observados na figura $7 \mathcal{B}$, não se utilizou o termo fibrose cicatricial adjetivado ou não. O espectro mais largo dificultaria o resgate das informações, mas não influenciaria na compreensão do diagnóstico, mas se usarmos o termo fibrose cicatricial adjetivado ou com descrições seguindo-o, o diagnóstico ficará mais esclarecedor e resgatável.

6.3.12 Papiloma e Hiperplasia Papilar Inflamatória

O papiloma reflete bem as questões terminológicas para algumas situações. Em alguns tratados, papiloma representa uma lesão viral, em outros é referido como lesãa fundamental. Papiloma também é considerado e citado como uma neoplasia benigna dos epitélios as sociada 
a traumatismos freqüentes sem conotação viral. O termo papiloma está incorporado na identificação do vírus $\mathcal{H} P V$, ou melhor, "papiloma vírus Gumano". A lesão típica do papiloma na mucosa bucal está bem estabelecida morfologicamente, mas em 114 casos, observados na figura $7 \mathcal{B}$, o termo papiloma foi incorporado a outros termos que dificultaria a identificação precisa desta lesão ne oplásica benigna associada ao $\mathcal{H} P V$. Há de reconfecer-se que apenas na última década o aprofundamento sobre o HPV se estabeleceude forma ampla e generalizada.

$\mathcal{A}$ favor da uniformização e precisão terminológica, o termo papiloma deveria ser reservado para identific ação da doença e nãa como termo descritivo ou identificador de lesões fundamentais na mucosa bucal. Nem todas lesões com projeções papilares para a superfície da mucosa sãa diagnosticadas como papiloma, pois sãa produtos de outros quadros etiopatogênicos também presentes na mucosa bucal.

$\mathcal{N o}$ palato duro tem-se um exemplo desta situação, quando do uso de prótese mal adaptada atritando constantemente a mucosa palatina e promovendo a fiperplasia papilar inflamatória, sem constatação viral ou re lação com o papiloma. 


\subsubsection{Granuloma Pe riapical}

O granuloma representa uma forma de organização na distribuição das células inflamatórias mononucleares, especialmente os macrófagos, durante o processo de cronificação inflamatória. O granuloma reflete a persistência de um agressor no tempo e na mesma região. Também denota a incapacidade de nossas células em destruir esse agressor ou em ter acesso a ele. Esta situação pode ocorrer em várias partes do corpo, inclusive ao redor do ápice dentário de dentes com necrose pulpar e contaminação dos condutos radiculares por uma microbiota mista com virulência variável. A doença assim caracterizada, de forma precisa quanto ao local e etiopatogenia, deve ser nominada como granuloma periapical.

$\mathcal{N}$ os resultados revelados na figura $7 \mathcal{B}$ muitos granulomas periapicais foram identificados como granuloma dental, inflamação crônica proliferativa, processo inflamatório crônico e outros. Tal como ocorre na literatura pertinente, houve casos diagnosticados equivocadamente como tecido de granulação. Este representa o tecido formado pelo conjuntivo vizinho as áreas agredidas para repará-las a partir da formação de um novo tecido conjuntivo. Granuloma representa a persistência do agente agressor e tecido de granulação a eliminação desse agressor seguida pelo reparo da área. 
$\mathcal{N}$ g granuloma periapical áreas de tecido de granulação podem ser observadas focalmente e não representam o porquê da ocorrência da lesão tecidual no local. O granuloma periapical caracteriza-se por uma inflamação crônica granulomatosa e imunogênica, induzida por agressões provenientes dos condutos radiculares e inacessiveis às nossas células, bem como às substâncias promotoras das defesas teciduais, oc asionando a cronific ação do processo.

\subsubsection{Cis to Periodontal Apical}

Quanto à nomenclatura, o grupo das lesões císticas dos maxilares tem sofrido muitas modificações conceituais e terminológicas. Algumas lesões foram excluídas do contexto por não se fundamentarem em quadros específicos e tão pouco explicáveis embriologicamente. Isto pode ser observado em lesões como: cisto mandibular, globulomaxilar e palatino mediano. Os cistos localizados no periodonto apical, decorrentes de estimulo à proliferação dos restos epiteliais da bainha de Hertwig ou restos epiteliais de Mallassez sãa mais precisamente diagnosticados como "cisto periodontal apical", pois este termo indica sua origem e a localização.

Várias lesões císticas podem envolver, associar-se ou ainda ter origem nas estruturas radiculares. O cisto periodontal lateral, alguns 
queratocistos odontogênicos ${ }^{21}$, o cisto colateral inflamatório ${ }^{45}$ e outros também ocorrem ao redor da raiz dentária; o termo cisto radicular não é preciso tanto quanto o cisto periodontal apical. O número de termos utilizados para identificar o cisto periodontal apical, observado na figura $7 \mathcal{D}$, também pode estar relacionado com a não aplicação de critérios diagnósticos como foi discutido no item sobre equívocos diagnósticos deste capítulo.

$\mathcal{A}$ terminologia ou nomenclatura na patologia representa a sinalização dos caminhos a serem trilhados no estudo e na pesquis a das doenças. $\mathcal{A}$ base na qual fundamentamos os novos passos do confecimento fumano está na fistória das gerações anteriores que representa o acúmulo de informações adquiridas. Sem terminologia ou nomenclatura precisa e padronizada, parte do tempo precioso das vidas no estudo e na pesquisa será perdido no labirinto de vários nomes que levam ao mesmo lugar por representarem o mesmo processo.

6.4 Dos diagnósticos revistos

Revisar um diagnóstico significa mudá-lo, implica em prováveis mudanças no prognóstico, tratamento e proservação. Também implica e m analisar as conseqüências do diagnóstico anterior. 
Em uma casuística de 13.140 casos, ao longo de 30 anos, rever diagnósticos com mudanças em 2.944 casos observados na figura 8 , representa muito pouco estatisticamente. Noão importa, se apenas uma mudança fosse detectada. Is to seria necessário e deve ser valorizado, não só pelo envolvimento do paciente, mas também pela oportunidade de aprendizado e aperfeiçoamento dos serviços prestados, otimizando arquivos e dados a serem utilizados e m pesquisas.

Após a conclusãa do trabalho, laudos de revisão serão e mitidos aos profissionais ainda em atividade para se tomar às providências cabíveis, quando assim se fizer necessário. Na maioria dos casos, as revisões não implicam em mudanças de conduta terapêutica e da proservaçãa. Os pacientes nãa sofreram conseqüências e nãa precisam ser localizados e reavaliados. Um exemplo: a revisão de granuloma periapical levou à mudança para cisto periodontal apical. Mas existem casos em que isto se faz importante: mudança de cisto dentigero para ame loblas toma unicistico, por exemplo.

\subsubsection{Granuloma $x$ Cisto periodontal apical}

Das lesões com revisão diagnóstica, o granuloma periapical representou $34,2 \%$ dos casos. A provável explicação está na origem do cisto periodontal apical _ o próprio granuloma periapical _ e no 
estabelecimento de critérios bem definidos, ao considerar esta transformação como iniciada e estabelecida.

Morfologicamente esta lesão apresenta uma porção central caracterizada por rica infiltração focal de polimorfonucleares neutrófilos e intensa proliferação angioblástica, além de micro abscessos na região correspondente e contigua ao coto periodontal. Esta faixa da lesão, não raro, após analisar as peças de uma curetagem cirúrgica, conduz ao diagnóstico descritivo de tecido de granulação.

Ao redor da área central, observam-se focos ou aglomerados de células mononucleares distribuídas e organizadas em arranjo granulomatoso; estes focos ou aglomerados encontram-se separad os por áreas com densos feixes de fíbras colágenas. Em algumas lesões, também se notam células pseudoxantomatosas, corpúsculos fialinos de Russel e cristais de colesterol circunscritos por células gigantes multinucleadas inflamatórias em reação tipo corpo estranfo. Este tipo de reação inflamatória crônica granulomatosa tipo corpo estrantio também pode ser observada frente a materiais extravasados durante o tratamento endodôntico e inseridos nos aspectos possíveis de serem encontrados no espectro microscópico do granuloma periapical. Na periferia, um tecido conjuntivo se organiza em forma capsular fibrosa. 
Fragmentos de tecido ósseo reacional periférico podem ocasionalmente serem vistos.

$\mathcal{N o}$ granuloma periapical há um componente epitelial. Embora cortes microscópicos seriados sejam necessários para detectar sua presença constante na lesão, em geral nos cortes para diagnóstico de rotina o granuloma periapical apresenta e pitélio ora em forma de ilhotas, ora em cordões distribuídos ao acaso. O componente epitelial do granuloma periapical deriva dos restos epiteliais de Malassez em quase todos os casos.

$\mathcal{N a ̃ o ~ s e ~ d e v e ~ d e s c a r t a r ~ a ~ p o s s i b i l i d a d e ~ d e ~ e v e n t u a i s ~ r e s t o s ~ d a ~ l a ̂ m i n a ~}$ dentária serem incorporados no granuloma periapical; no ligamento periodontal os restos epiteliais da lâmina dentária podem estar presentes. De $0,5 \%$ a $0,7 \%$ dos cistos localizados no periápice são queratocistos odontogênicos ${ }^{45}$, provavelmente derivados desta estrutura epitelial. VERBI $\mathcal{N}^{54}$ aventa a possibilidade da origem deste epitélio cístico a partir da mucosa do seio maxilar pela sua invasão. Afirma ainda, que pode resultar do epitélio bucal por meio de um trajeto fistuloso ou de epitélio bucal estendendo-se apicalmente por uma bolsa periodontal.

HARRIS ON L LARSO $\mathcal{N}^{26}$ ao descrever os cortes microscópicos de fistulas derivadas de processos inflamatórios dentoalveolares, 
observaram que o epitélio da superfície não invadia a fístula, apenas a contornava no máximo até $3 \mathrm{~mm}$ além de sua abertura. Quanto à associação do epitélio do granuloma periapical com a bols a periodontal, deve-se relevar que cistos assim originados são raros e identificados como cisto colateral inflamatório e não periodontal apical.

$O$ cisto periodontal apical tem sua origem a partir do granuloma periapical, no qual microscopicamente observa-se uma cavidade patológica pequena ou bem definida revestida na grande maioria, por epitélio não queratinizado ora atrófico, ora fiperplásico. Por um tempo considerável ao redor da cavidade, subjacente ao e pitélio, a organização tecidual será ainda de um granuloma periapical. As camadas superficiais e pite liais encontram-se desorganizadas e ausentes. Ainda na superficie, podem ser notados corpúsculos hialinos de Rushton que são depósitos de material esinofilico ora irregulares, ora circulares ou ovalados e de pouco valor prognóstico. De permeio às células epiteliais com freqüência se observam leucócitos polimorfonucleares e mononucleares.

Outros tipos de epitélio podem revestir a cavidade cística, e mbora de forma parcial alternando com o padrão estratificado pavimentoso. Assim, pode se observar epitélio respiratório pseudoestratificado ciliado, epitélio simples constituído por células cubóides associado a células mucosas tipo caliciformes oriundas de me taplasia mucosa. 
$\mathcal{N}$ o lume cístico pode-se notar presença de material esinofílico amorfo, cristais de colesterol, células pseudoxantomatosas, leucócitos mononucleares e polimorfonucleares, hemácias, células epiteliais descamativas e eventualmente estruturas semelhantes a lâminas de que ratina.

$\mathcal{A}$ parede cística formada por tecido conjuntivo fibroso capsular e tecido granulomatoso, freqüentemente apresenta variável infiltrado inflamatório predominantemente mononuclear ora focal, ora difuso. Ocasionalmente, observam-se células gigantes inflamatórias de reação tipo corpo estranho circundando cristais de colesterol, como também fragmentos de material obturador. Alguns casos podem apresentar reação granulomatosa tipo corpo estranko associada à presença de fragmentos vegetais, embora is to seja um achado ocasional.

As características morfológicas tanto do granuloma periapical como do cisto periodontal apical descritas anteriormente foram observadas

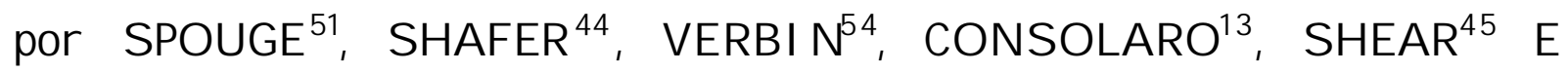
$O \mathcal{D E} \mathcal{L L}^{34}$

$\mathcal{N o s}$ granulomas periapicais podem ser observados ilhotas e cordões epiteliais. Esse epitélio com capacidade proliferativa, mediante a estimulos presentes na inflamação representada pelo granuloma periapical, prolifera-se e pode dar origem a um cisto. $\mathcal{A}$ simples 
presença de epitélio nos granulomas periapicais anula-o como critério para o diagnóstico de cisto periodontal apical, pois está presente em todos os granulomas periapicais quando observados em cortes se riados. Por outro lado, sua existência associada à formação de cavidade nos permite diagnosticar a lesão como um cisto periodontal apical. $\mathcal{A}$ observação dessa cavidade é imprescindivel para o diagnóstico de cisto periodontal apical. Dependendo do estágio de formação da cavidade e da fragmentação cirúrgica da lesão, a sua visualização diagnóstica pode ficar comprome tida à análise microscópica.

$\mathcal{A}$ definição diagnóstica entre granuloma periapical ou cisto periodontal apical pode parecer arbitrária. No exame microscópico das peças cirúrgicas curetadas utiliza-se, desde 1987, como critério para definir o diagnóstico entre cisto periodontal apical e granuloma periapical, a presença de epitélio nas superfícies destes fragmentos obtidos. O epitélio na superfície assume características próprias da pavimentação, uma de suas funções primárias e considera-se a existência de uma cavidade virtual em função da fragmentação cirúrgica da peça. Nos cortes microscópicos de granuloma periapical curetado, não fía como observar reves timento e pitelial pavimentoso na superfície dos fragmentos removidos e enviados. Pode-se até reconfece-los, mas 
incluidos na estrutura central dos fragmentos teciduais e não revestindo superficies.

$\mathcal{A}$ presença de inflamação associada e exuberante, principalmente nos casos incipientes, desorganiza o epitélio e pode dificultar a sua identificação. A adoção de critérios bem definidos e treinamento do observador permite uma significante padronização. Quando a peça é enviada inte ira ou aderida ao ápice dentário, a identificação da cavidade fica macro e microscopicamente facilitada.

$\mathcal{A}$ possibilidade de se associar os achados microscópicos com a fistória clínica pode facilitar o esclarecimento do tipo de lesão, mas muitas fichas de envio das peças cirúrgicas não apresentavam relatos clínicos ou eram precários. A descrição macroscópica detalhada, outro recurso fundamental no auxílio à análise microscópica, somente passou a ser rotina registrada nos laudos a partir de 1987. Os casos com diagnósticos revistos são anteriores a esta data, provavelmente pela falta de padronização e adoção de critérios claros, definidos e utilizados por todos os observadores.

Mesmo na literatura pertinente, a definição de critérios para análise microscópica e diferença de granuloma periapical e cisto periodontal apical, ainda não está clara e definitivamente es tabelecida. 
$\mathcal{A}$ alteração diagnóstica de granuloma periapical para cisto periodontal apical ocorreu em casos de lesões císticas fragmentadas com intenso componente inflamatório. Estas apresentavam apenas fragmentos de epitélio difice is de serem visualizados pela associação com processos inflamatórios extensos e procedimentos macroscópicos não padronizados. Em relação a estas lesões, a mudança no diagnóstico não alteraria o tratamento e prognóstico.

Considerando a inclusão deste material em pesquisas quanto à análise de evolução clínica, prognóstico e correlação com imagens radiográficas e quadros clínicos, a correção diagnóstica se faz importante.

6.4.2 Cis to Residual $\chi$ Ame loblastoma Unicístico $\chi$ Que ratocis to

Odontogênico X Cisto dentígero

$O$ cisto residual trata-se de um cisto periodontal apical sem o dente do qual se originou a lesão e não representa primariamente uma nova entidade clínica. Morfologicamente é idêntico ao cisto periodontal apical, já descrito anteriormente. Como constatado por ofHLERS ${ }^{35}$, essas lesões residuais regridem após a remoção do dente relacionado em intervalos de meses a anos. 
Quando se detecta uma lesão radiolúcida, cística e isolada, muitas vezes pode não ser um cisto periodontal apical tipo residual, mas sim um queratocisto odontogênico, ou mesmo um ameloblastoma unicístico ou outros tumores odontogênicos. Alguns casos descritos anteriormente como cistos residuais, revelaram-se tratar principalmente de que ratocisto odontogênico (figura 9D).

$\mathcal{A}$ análise radiográfica da áre a auxilia no diagnóstico microscópico se houver um curto intervalo de tempo entre a exodontia e a remoção cirúrgica da lesão. Nelas pode-se observar uma continuidade do alvéolo com a lesão, um sinal seguro no diagnóstico de cis to residual.

Alguns cistos residuais podem apresentar metaplasia escamosa, embora seja um achado raro ${ }^{47}$. Neste caso, o diagnóstico diferencial de queratocisto odontogênico deve ser criterioso. $\mathcal{A}$ lesão deve ser totalmente processada e examinada através de cortes microscópicos seriados, uma vez que o queratocisto odontogênico apresenta características microscópicas distintas e seu diagnóstico não se limita a simples presença de queratinização. $\mathcal{A}$ presença de infiltrado inflamatório exuberante e difuso dificulta o diagnóstico conclusivo de que ratocis to odontogênico.

Atenção também deve ser dada a presença dos critérios estabelecidos por VICKERS; GORLI $\mathcal{N}^{55}$ para o diagnóstico de 
ameloblastoma, e como ressaltado por eles, estes critérios precisam estar presentes no conjunto, pois outras entidades clínicas podem apresentar alguns desses critérios isoladamente.

$\mathcal{A}$ alteração diagnóstica de cisto residual para queratocisto odontogênico e ameloblastoma unicístico determina mudança na proservação do caso. Também se pode instituir um tratamento conservador para o ameloblastoma unicístico pela sua baixa invasividade e menor indice de recorrência em relação ao ameloblastoma sólido. Nesses casos deve ser feita a proservação por um período de tempo mais longo e com intervalos menores entre os reexames.

O queratocisto odontogênico é um cisto de desenvolvimento com características microscópicas peculiares. O epitélio cístico uniforme apresenta-se, na maioria, paraqueratinizado com duas a oito camadas de células e com inconspícuas cristas epiteliais. Em sua superfície freqüentemente notam-se corrugações. A camada basal revela-se bem de marcada e constituída por células colunares ou cuboidais dispostas em paliçada e com núcle os fipercromáticos. Em alguns casos essas células também apresentam polarização reversa. A interface epitélio conjuntivo é frágil e comumente observam-se disjunções focais. Também freqüente é a fialinização justaepitelial presente em algumas áreas. Estas características foram originalmente descritas em 1956 por 


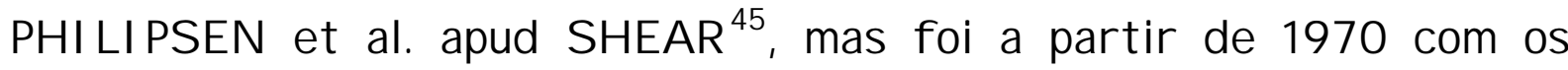

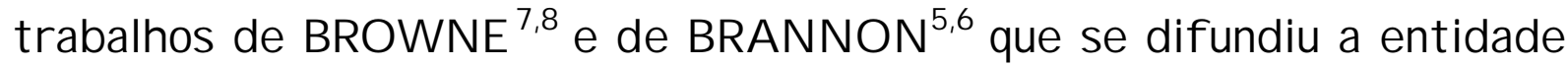
clínica de forma clara e universalmente aceita.

$\mathcal{A}$ cápsula fibrosa apresenta-se fina com ausência de infiltrado inflamatório. Observam-se ainda, cistos satélites, pequenas formações císticas com acúmulo central de queratina, bem como ilfotas ou cordões de epitélio odontogênico. Outros achados como corpúsculos fialinos de Russele cristais de colesterol são ocasionais e distribuidos focalmente.

O diagnóstico de queratocisto odontogênico tem sua importância relacionada à alta taxa de recorrência, fistórico de malignizações e a possibilidade de ser um componente sindrômico. $\mathcal{A}$ presença de infiltrado inflamatório, dependendo da intensidade, pode dificultar o diagnóstico pela perda da queratinização e fiperplasia do e pitélio. Essa situação pode dificultar um diagnóstico seguro e preciso.

O ameloblastoma unicístico foi descrito inicialmente por ROBSONi $\mathcal{M A R T I} \mathcal{N E Z}^{43}$ e m 1977 e posteriormente classificado por $\mathcal{A C K E R M A \mathcal { N }}$;

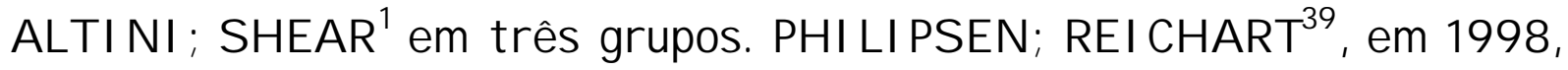
interpretaram e modificaram esta classificação. Nomearam os três grupos existentes e acrescentaram um quarto tipo tornando-a mais didática e de fácil compreensão. 
O primeiro, simples ou luminal, consiste de uma cavidade revestida parcialmente por epitélio ameloblastomatoso. $\mathcal{A}$ camada basal apresenta-se constituída por células cubóides ou colunares com núcleos hipercromáticos e polarização invertida, além de vacuolização citoplasmática basilar. As células suprabasais revelam-se dispostas frouxamente com presença de espaços intercelulares lembrando re tículo estrelado.

O segundo, simples e intra-luminal, caracteriza-se pela prolife ração e pitelial para o interior da cavidade cistic a freqüente mente com padrão plexiforme. Algumas lesões císticas podem apresentar proliferação epitelial semelhante a este padrão plexiforme. Como ressaltado por $G \mathcal{A R D N} \mathcal{E R}^{19}$, estas lesous necessitam ser analisadas criteriosamente em cortes microscópicos seriados para identificação dos critérios de VICRERS; GORLI $\mathcal{N}^{55}$.

O terceiro, simples e intramural, revela uma prolife ração do e pitélio de revestimento cístico para o interior da cápsula fibrosa com padrão folicular ou plexiforme.

O último tipo, além de simples e intraluminal também intramural, caracteriza-se por apresentar proliferações epiteliais tanto para o lume cístico quanto para cápsula cística. Os dois últimos tipos são mais recidivantes, pela infiltração intramural ${ }^{20}$, embora ocorra com indices 
menores que o ameloblastoma sólido e em períodos de tempo mais longos.

O ameloblastoma unicístico simples com proliferação luminal não apresenta características ameloblastomatosas em toda extensão epitelial, assim ressalta-se que a análise criteriosa de cortes microscópicos semi-seriados de toda lesão é essencial para um diagnóstico seguro e preciso de ameloblastoma unicístico.

O reconfecimento do ameloblastoma unicístico como entidade clínica é relativamente recente ${ }^{43}$ (1977), vários foram os casos revistos com alteração diagnóstica para esta lesão, como mostra a figura $9 \mathcal{A}$. $\mathcal{A}$ mudança provavelmente não alteraria significantemente tratamento e prognóstico, apenas exigiria uma maior proservação.

$O$ cisto dentigero é um cisto de desenvolvimento aderido ao nível da junção amelocementária de um dente não irrompido. Microscopicamente observa-se uma cavidade revestida por epitélio não queratinizado com duas a três camadas de células achatadas, planas ou cubóides, que podem ser semelhantes ao epitélio reduzido do esmalte, de onde têm sua origem. Ocasionalmente são observadas áreas de me taplasia mucosa e de queratinização superficial. Eventualmente, o epitélio do cisto dentigero pode ser mais espesso e organizado como um epitélio estratificado pavimentoso com várias camadas celulares ${ }^{21}$. 
$\mathcal{A}$ cápsula cística apresenta-se constituída por tecido conjuntivo bem celularizado com delicadas fibras colágenas. Freqüentemente notam-se ilhotas e cordões de epitélio odontogênico. Essas ilhotas, nãa raro, podem apresentar vacuolização citoplasmática e área central semelhante ao retículo estrelado. Esses achados muitas vezes conduzem ao diagnóstico de ameloblastoma se desenvolvendo na parede de um cisto dentigero, sem ter tido a preocupação de identificar-se os critérios de VICKERS; GORLI $\mathcal{N}^{55}$. Muitos casos de ameloblastomas murais $^{22,29,38}$ podem ter sido diagnosticados precipitadamente. $\mathcal{A}$ aplic ação de critérios morfológicos deve ser rigorosa e segura.

$\mathcal{C A H \mathcal { N }}{ }^{10}$ em 1933 afirmou ser o cisto dentigero um ameloblastoma em potencial, porém se faz necessário o diagnóstico microscópico inicial de cisto dentígero e posteriormente o de ameloblastoma unicístico para embasar essa afirmação. Os casos apresentados por $\mathcal{M C} \quad \mathcal{M I L L A \mathcal { N }}$ $S \mathcal{M I L L I \mathcal { E } ^ { 3 3 }}$ em 1981 reiteram a teoria de $\mathcal{C A} \mathcal{H N}^{10}$, mas na realidade mostram cortes microscópicos de ameloblastomas unicísticos. Em um dos casos apresentados observou-se ilhotas ameloblastomatosas na parede do cisto dentigero.

LEIDER; EVERSOLE; BARKI $\mathcal{N}^{31}$ discutem a patogênese do ame loblastoma unicístico associado à coroa de um dente não irrompido. Para eles a lesão pode começar como um neoplasma novo a partir de um 
folículo pericoronário, ou originar-se de um cisto odontogênico pré existente. Uma terceira fipótese propõe a "degeneração" cística de ilhotas ameloblásticas com subseqüente fusão de múltiplos cistos e desenvolvimento de uma les ão unicística.

O aspecto ameloblástico das células encontradas no epitélio reduzido do esmalte em suas camadas superficiais, a organização papilar das camadas subjacentes, a rica presença de ilhotas epiteliais originárias da lâmina dentária nos folículos pericoronários e os procedimentos cirúrgicos que levam à fragmentação da peça obtida e enviada para análise, podem levar a equívocos diagnósticos e precipitação, identificando-se células ameloblásticas não verdadeiramente neoplásicas em folículos pericoronários. $\mathcal{A}$ estruturação morfológic a foi de monstrada por CONSOLARO ${ }^{11}$ em 1987 .

O diagnóstico de ameloblastoma unicístico se desenvolvendo em cisto dentigero foi atribuído por $\mathcal{S} \mathcal{H} \mathcal{E} \mathcal{A R}{ }^{45}$ como um erro diagnóstico inicial de cisto dentigero baseado apenas em dados radiográficos, e posterior análise microscópica de uma área biopsiada não representativa da lesãa.

Casos com ilhotas epiteliais presentes na cápsula cística apresentando aspectos morfológicos semelhantes ao ameloblastoma foram valorizados por $\mathcal{Y A A C O B}^{58}$. Todavia, essas ilhotas observadas 
criteriosamente não apresentam o conjunto de critérios estabelecidos por VICRERS; GORLI $\mathcal{N}^{5}$ para o diagnóstico de ameloblastoma. $\mathcal{A}$ presença de alterações pseudoameloblastomatosas também pode ocorrer em cistos periodontais apicais ${ }^{49}$. Na revisão desta dissertação, vários foram os casos com diagnóstico de ameloblastoma se desenvolvendo na parede de um cisto dentigero, onde se observavam ilhotas epiteliais apenas com alguns dos critérios de VICRERS; GORLI $\mathcal{N}^{5}$ (figura 9D).

Alguns cistos dentigeros podem apresentar metaplasia escamosa, porém esta alteração é rara e focal. O exame de um fragmento da lesão que apresente queratinização pode conduzir ao diagnóstico errôneo de que ratocisto odontogênico. A simples presença de queratinização, como já mencionado, não é sufic iente para este diagnóstico; faz-se necessário observar a presença das demais características morfológicas distintas do que ratocisto odontogê nico.

6.4.3 Ame loblastoma sólido X Ame loblastoma unicístico

O ameloblastoma sólido é um neoplasma benigno de origem odontogênica e localmente invasivo. Microscopicamente apresenta os seguintes padrões: folicular, plexiforme, acantomatoso, de células granulares, Gasalóide e desmoplásico. Os padrões folicular e plexiforme 
são os mais comuns. Os padrões morfológicos do ameloblastoma foram revistos no trabalfo de $\mathcal{V} \hat{E} \mathcal{N} C I O^{53}$.

O ameloblastoma folicular caracteriza-se por ilfotas ameloblastomatosas constituídas de células periféricas colunares ou cubóides dispostas em paliçada com vacuolização citoplasmática e polarização reversa, semelhante à pré-ameloblastos. As células centrais são poliédricas e se apresentam edemaciadas com os contatos intercelulares proeminentes lembrando o reticulo estrelado do órgão do esmalte.

O padrão plexiforme consiste de longos cordões ou placas de epitélio odontogênico anastomosados. As células periféricas são colunares ou cuboidais semelhantes à pré-ameloblastos, porém sema morfologia clássica ameloblástica. As células centrais apresentam-se arranjadas frouxamente, embora de uma forma menos estrelada que o padrão folicular. O estroma revela um tecido conjuntivo bem colage nizado e vascularizado.

O ameloblastoma acantomatoso considerado uma variante do folicular, caracteriza-se por extensas áreas de ilhotas ame loblas tomatosas com me taplasia escamosa central.

O ameloblastoma de células granulares caracteriza-se pela substituição das células basais e/ou centrais por células poliédricas ou 
arredondadas contendo grânulos eosinófilos no citoplasma e núcleos periféricos, além de picnóticos. As características morfológicas dos diversos subtipos de ameloblastoma foram descritas por $\mathcal{F E} I \mathcal{N}(\mathcal{B E R}$;

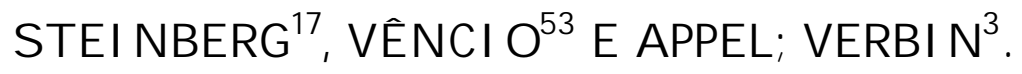

Dos casos de ameloblastoma sólido revisados, alguns apenas foram classificados morfologicamente, outros tiveram sua classificação morfológica alterada. Assim, pode-se inferir que houve um refinamento no diagnóstico não alterando sua essência. Nesses casos, para a época, tratamento e prognóstico não seriam alterados. Apenas mais recentemente evidenciou-se grau diferente de agressividade entre os subtipos morfológicos dos ame loblastomas sólidos ${ }^{52}$.

$\mathcal{A}$ alteração diagnóstica de ameloblastoma sólido para ame loblastoma unicis tico explica-se pelo reconfecimento, relativamente recente, desta última como entidade clínica. Considerando que o ameloblastoma unicistico tem baixa capacidade proliferativa e baixo potencial de recidiva, a mudança permitiria um tratamento conservador e tornaria o prognóstico mais favoráve ${ }^{18,52,5742}$. Esta afirmação é válida em se tratando de lesões mandibulares. Na maxila, o tratamento ainda seria invasivo devido à contigüidade com as estruturas vitais na base do crânio ${ }^{17,57}$. 


\subsubsection{Folículo pericoronário X Cisto dentígero}

O folículo pericoronário, estrutura remanescente da odontogênese, caracteriza-se por apresentar uma parede de tecido conjuntivo fibroso com organização capsular e áreas de tecido mixóide. Notam-se ainda, mine ralizações ocasionais, restos de epitélio odontogênico em forma de cordões ou ilhotas, bem como presença de infiltrado inflamatório. Este último, freqüente em folículos de dentes parcialmente rompidos e discreto ou praticamente ausente em dentes não irrompidos.

CONSOLARO ${ }^{11}$, além das observações anteriores, também constatou uma variação morfológica dos folículos pericoronários relacionada a aspectos como a erupção dentária parcial ou sua ausência, o tempo de permanência no alvéolo e a presença de infiltrado inflamatório. Também afirmou que o quadro microscópico de cisto dentigero, especialmente os incipientes, não permite um diagnóstico diferencial seguro com o folículo pericoronário de dente não irrompido.

O cisto dentigero é um cisto de desenvolvimento, formado a partir do folículo pericoronário. Sua morfologia já descrita anteriormente assemelha-se a de seu precursor. Um espessamento deste, radiograficamente mimetizará um cisto dentigero. Sua diferenciação dependerá de dados clínicos durante a remoção da lesão, como a presença de líquido entre a coroa e os tecidos foliculares ${ }^{14}$. 
$\mathcal{A}$ revisão diagnóstic a de cisto dentígero para folículo pericoronário ou sua recíproca não alteraria tratamento e prognóstico. Esses diagnósticos não puderam ser avaliados devido à ausência do resumo clínico nas fichas de envio das peças cirúrgicas. Eles foram apenas confirmados, pois provavelmente obtiveram-se as informações pertinentes por diálogos entre patologista e clínico.

6.4.5 Carcinoma odontogênico de células claras x Carcinoma espinocelular x Carcinoma mucoe pidermóide

O carcinoma odontogênico de células claras, ainda se apresenta com a nomenclatura de tumor odontogênico de células claras, segundo a classificação da Organização Mundial de Saúde (OMS $)^{30}$ de 1992.

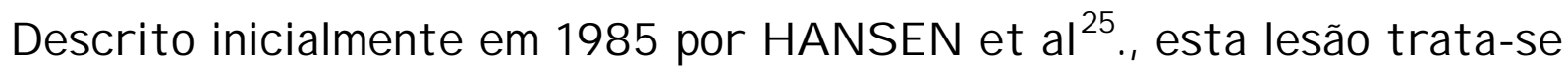
de uma neoplasia rara e infiltrativa. Sua alta recorrência e as metástases para nódulos linfáticos regionais denotam seu comportamento biológico agressivo e justificam a nomenclatura de carcinoma odontogênico de células claras.

Sua morfologia caracteriza-se por extensa proliferação ora de ilhotas, ora de cordões de células claras com núcleos redondos ou ovóides e intercaladas por septos de conjuntivo fibroso. Essas células, na maioria, apresentam acúmulos de glicogênio no citoplasma 
identificados pela diastase realizada na coloração de pAs lácido periódico de $S$ chiff) dos cortes micros cópicos. Outros tipos celulares como células mucosas também podem se observadas. Infiltração perineural e intramuscular são achados freqüentes, bem como discreto pleomorfismo e algumas figuras de mitose. O estroma apresenta-se ora frouxo a fialinizado, ora fibroso. Em alguns casos pode-se notar perifericamente condensação de tecido fibroso assumindo aspecto capsular.

O predominio de células claras é distinto do carcinoma odontogênico de células claras, mas o carcinoma mucoepidermóide também pode apresentar numerosas células claras dificultando o diagnóstico. Esses casos requerem a confirmação diagnóstica pela diastase na coloração de PAS. Esta será positiva em casos de carcinoma odontogênico de células claras.

O carcinoma odontogênico de células claras e o carcinoma mucoepidemóide são lesões que apresentam vários padrões de crescimento como também tipos celulares diversificados. Alguns casos de carcinoma mucoepidermóide com numerosas células claras necessitam de uma análise criteriosa que possibilite um diagnóstico seguro. Embora pouco descrito na literatura, os relatos existentes do 
carcinoma odontogênico de células claras são incisivos quanto a predominância de células claras nestas lesões.

O carcinoma mucoepidermóide é o neoplasma maligno de glândula salivar mais comum. Microscopicamente se caracteriza pela presença de células mucosas com núcleos periféricos e citoplasma finamente granular, além de células epidermóides poligonais com núcleos vesiculares e abundante citoplasma e células intermediárias ovais lembrando células basais, embora menores. Esses tipos celulares distribuem-se formando ilhotas sólidas ou revestindo espaços císticos. $\mathcal{N}$ otam-se ainda, células claras poligonais e m número variável, na maioria, com traços de mucina no citoplasma.

o estroma pode apresentar-se desmoplásico com parcial distribuição capsular das fibras colágenas periféricas. A presença de moderado pleomorfismo celular associado à proliferação hipercelular sólida pode ser observada em lesões mais agressivas. A presença de pequenas estruturas císticas e/ou glandulares auxilia na diferenciação com o carcinoma espinocelular. Ocasionalmente podem ser observadas áreas mixóides e condróides.

Os aspectos morfológicos do carcinoma mucoepidermóide e do carcinoma odontogênico de células claras descritos, foram observados por AUCLAIR; $\mathcal{E L L I S} S^{4,15}$ e CONSOLARO et al $l^{12}$. 
O carcinoma espinocelular é das neoplasias malignas a mais comum. Caracteriza-se pela proliferação de células epiteliais em forma de cordões, ilhotas ou mesmo isoladas. Essas células assemelham-se as da camada espinfosa do revestimento epitelial. As lesões com queratinização acentuada, pouca figuras mitóticas, e discreto pleomorfismo nuclear e celular são classificadas como de grau 1 ou bem diferenciadas pela Organização Mundial de Saúde (OMS $)^{41}$. As lesões de grau 2 ou moderadamente diferenciadas apresentam menor queratinização que as de grau 1, mais pleomorfismo celular e nuclear, bem como maior número de figuras mitóticas. As lesões de grau 3 ou pouco diferenciadas apresentam inúmeras figuras de mitoses com presença de mitoses atípicas, além de acentuado pleomorfismo celular e nuclear com presença de células multinucleadas. Esta gradação se faz importante no estabelecimento do tratamento e prognóstico.

$\mathcal{N a}$ casuística analisada um caso de carcinoma odontogênico de células claras foi diagnosticado como carcinoma espinocelular, observado na figura $9 \mathcal{D}$, e um segundo caso diagnosticado como carcinoma mucoe pidermóide, apresentado na figura 9C. Atribui-se estes diagnósticos provavelmente pelo desconfecimento desta entidade até 1985. 
6.4.6 Sialome taplasia necrotizante $\chi$ Carcinoma mucoepidermóide

$\mathcal{A}$ sialometaplasia necrotizante é uma lesão benigna inflamatória, necrotizante e auto limitante de glândulas salivares. Freqüentemente seu aspecto clínico e microscópico conduz ao diagnóstico errôneo de carcinoma mucoepidermóide ou carcinoma es pinoc elular ${ }^{16,24}$.

$\mathcal{A}$ les ão representa um infarto anêmico das glândulas salivares principalmente no palato e na região do soalho bucal. As características microscópicas revelam glândulas salivares menores apresentando duc tos com metaplasia escamosa, espessamento da parede e retenção de material mucóide em seu interior. Os ductos resistem, persistem e se adaptam à pressão, mas as células acinais sucumbem. De permeio, observa-se a presença de infiltrado inflamatório mononuclear e polimorfonuclear. Áreas de extravasamento mucoso circundadas por exuberante tecido de granulação, também podem ser encontradas.

A mucosa bucal suprajacente, na maioria, apresenta-se revestida por epitélio estratificado ora fiperplásico e pseudoe piteliomatoso, ora atrófico e ulcerado recoberto por extensa camada de exsudato serofibrinoso intensamente infiltrado por numerosos leucócitos polimorfonucle ares. 
Algumas lesões originam-se espontaneamente, mas a maioria está associada a trauma local seguido do infarto das glândulas salivares. Como a lesão apresenta vários estágios no seu desenvolvimento,o momento da biópsia determinará o quadro microscópico a ser observado. O confecimento das diversas etapas evolutivas desse processo é determinante no diagnóstico diferencial com o carcinoma mucoe pidermóide e o carcinoma es pinocelular.

$\mathcal{A}$ freqüente fiperplasia pseudoepiteliomatosa do epitélio de revestimento aumenta a dificuldade do diagnóstico. Casos com diagnóstico de carcinoma espinocelular, na microscopia revelam áreas de epitélio ductal metaplásico que devido ao plano de corte do bloco de parafina parecem contiguos com o epitélio de revestimento pseudoepiteliomatoso da mucosa bucal. Os aspectos microscópicos descritos foram observados por GRILLO $\mathcal{N}^{24}$ e g $\mathcal{E N S} \mathcal{E N}^{28}$.

$\mathcal{A}$ alte ração diagnóstica entre essas lesões muda o tratamento e o prognóstico, uma vez que a sialometaplasia necrotizante é uma lesão benigna com auto resolução. Em um dos casos, esta alteração diagnóstica foi necessária (figura 9C). Novamente evidencia-se a importância do rigor no estabelecimento de critérios de diagnóstico. O equívoco diagnóstico pode levar a mutilações desnecessárias. 
6.4.7 Hiperplasia fírosa inflamatória X Fibroma odontogênico periférico

A hiperplasia fibrosa inflamatória caracteriza-se microscopicamente pela hiperplasia do tecido conjuntivo fibroso bem vascularizado com infiltrado inflamatório mononuclear ora intenso, ora discreto. Estas fiperplasias decorrem do reparo com constante fibrosamento devido a traumatismos repetidos sobre uma área, por longos periodos de tempo. Ocasionalmente se observam glândulas salivares acessórias com atrofia acinar e fibrose intersticial, be m como presença de metaplasia óssea. Áreas mixóides são comuns em lesões removidas da região retromolar e nas lesões submetidas a trauma freqüentes.

O fibroma odontogênico periférico segundo a Organização Mundial de Saúde (OMS $)^{30}$ é uma ne oplasia rara. No entanto não é o que revelam nossos arquivos. Morfologicamente apresenta-se constituido de tecido conjuntivo ora mixóide, ora fibroso com intensa proliferação de células ovóides ou redondas, podendo apresentar ilhotas ou cordões de epitélio odontogênico. Como o epitélio nem sempre está presente,o diagnóstico diferencial com a hiperplasia fibrosa inflamatória deve-se relacionar com os achados microscópicos observados e a fistória clínica. 
$\mathcal{A}$ alteração diagnóstica não traz mudanças substanciais no tratamento e prognóstico. Porém, por uma cirurgia ligeiramente mais invasiva nos casos de fibroma odontogênico periférico evitaria as recidivas mais freqüentemente observadas. Um fator importante nesses casos está na recidiva. Quando o profissional remove a lesão com diagnóstico clínico de fiperplasia fibrosa inflamatória, quase sempre o fibroma odontogênico periférico assim diagnosticado microscopicamente, recidivará.

6.4.8 He mangioma capilar x Granuloma piogênico

O hemangioma capilar caracteriza-se por proliferação neovascular. Microscopicamente observa-se intens a proliferação angioblástica e m um estroma de tecido conjuntivo com delicadas fibras colágenas. Nota-se ainda, ausência de infiltrado inflamatório.

O granuloma piogênico é uma resposta reacional a um estimulo de baixa intensidade e longa duração. Morfologicamente constitui-se de exuberante tecido de granulação apresentando intensa proliferação neovascular associada a um exuberante infiltrado inflamatório mononuclear e polimorfonuclear. Freqüentemente no revestimento epitelial suprajacente observa-se área de ulceração recoberta por me mbrana serofibrinosa. 
$\mathcal{A}$ presença de infiltrado inflamatório em hemangiomas capilares ulcerados dificulta o diagnóstico diferencial com o granuloma piogênico. Nesses casos se fará necessário correlacionar os achados microscópic os com a fistória clínica.

$S P E \mathcal{T} I C^{50}$ constatou menor número de mastócitos marcados pela técnica de imunofistoquimica nos granulomas piogênicos quando comparados com a marcação realizada nos hemangiomas capilares. Ainda sugere ser possivel diferenciar essas lesões na ausência de relatos clínic os utilizando essa técnica.

$\mathcal{A}$ revisão diagnóstic a dessas lesões não alteraria tratamento e prognóstico, mas induziria o resgate da fistória familiar, da causa indutora da les ão e daria perspectiva mais segura do risco de recidiva.

6.4.9 Osteoblastoma X Displasia fibrosa

O osteoblastoma é uma neoplasia óssea de crescimento continuo sem formação de osso periférico reacional. Caracteriza-se microscopicamente por apresentar centralmente trabéculas de osso imaturo com intensa atividade osteoblástica e marcante presença de células clásticas. Na periferia observa-se formação de osteóide em cordões ou trabéculas disformes irradiadas. Envolvendo a les ão nota-se te cido conjuntivo capsular ${ }^{27}$. 
$\mathcal{A}$ displasia fibrosa dos maxilares é uma lesão benigna, caracterizada pela presença de tecido conjuntivo fibroso altamente celularizado com proliferação de células ora ovóides, ora redondas, apresentando de permeio trabéculas de osso não lamelar imaturo, tipicamente não revestido por osteoblastos. Nos estágios mais avançados da lesão observa-se a presença de osso trabecular em um estroma de tecido conjuntivo moderadamente celularizado ${ }^{27}$.

Aspectos microscópicos das lesões ósseas requer um treinamento e um acompanfiamento rígido e atualizado dos critérios diagnósticos. os maxilares as lesões ósseas neoplásicas e pseudotumorais conceitualmente evoluíram muito nas últimas décadas.

$\mathcal{A}$ displasia fibrosa dos maxilares pode apresentar áreas com múltiplos aspectos simuladores de outras lesões: pode ser predominantemente celular e fibrosa, osteogênica com predominância celular e fibrosa, osteogênica com predominância osteoclástica e ainda osteogênica com predominância clástica especialmente na região periférica na interface com o osso normal. A tentativa em diagnosticar exclusivamente levando-se em consideração os aspectos microscópicos aumenta e muito a chance de erro. A interação com imagem radiográfica e com os aspectos clínicos e características do perfil do paciente diminui e muito esse risco. Em outros tempos esta relação patologista e 
clínico era quase que burocrática; atualmente estimula-se e valoriza-se a inter e multidisciplinaridade.

Provavelmente esses aspectos influenciaram no diagnóstico de osteoblastoma para um caso de displasia fibrosa dos maxilares observado na figura 9C. A biópsia da periferia da lesão ressaltou a presença de clastos. Este fato associado à falta de informação sobre a lesão ser difusa ou nãa, além do aparente encapsulamento, evidenciado nas imagens radiográficas, explic a o equívoco ocorrido.

6.4.10 Carcinoma 6asocelular X Carcinoma espinocelular

Ao analisar comparativamente ameloblastoma e carcinoma

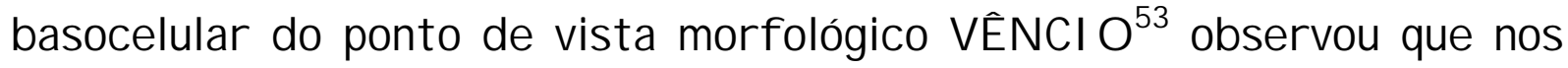
últimos 15 anos a literatura não mais publicou ou mencionou a possibilidade do carcinoma basocelular se originar na mucosa bucal. Essa lesão tem suas origens nos anexos epidérmicos, ausentes na mucosa bucal. Neste seu trabalho verificou-se semelhança organizacional entre carcinoma basocelular e ameloblastoma, especialmente a sua forma periférica quase sempre gengival; os anexos na mucosa estariam representados pelo órgão do esmalte. Alguns carcinomas espinocelulares podem se organizar e apresentar células cuja morfologia lembram as células basalóides dos carcinomas basocelulares; em outras regiões ou 
em cortes mais aprofundados na peça cirúrgica incluída, mostrará que se trata de variações morfológicas do carcinoma espinocelular. Quando o diagnóstico de carcinoma basocelular se estabelecer morfologicamente na mucosa bucal, devemos estar frente provavelmente a um ameloblastoma periférico. Em nossa amostra foi encontrado e revisto um caso de espinocelular diagnosticado equivocadamente como carcinoma basocelular (figura 9D); o prognóstico pode ser bem diferente, muito embora casos de carcinoma basocelular também possam ser agressivos.

6.4.11 Outras alterações diagnósticas

$\mathcal{N a}$ casuística revista constatou-se mudança de diagnóstico para as seguintes situações:

- Um adenoma pleomórfico na realidade se tratava de adenocarcinoma. Ainda hoje, o diagnóstico das lesões tumorais de glândulas salivares tem critérios as vezes controversos e extremamente subjetivos. Entretanto são muito mais claros e definidos quando comparados aos utilizados e m 1969, à época do diagnóstico.

- Um caso de osteomielite crônica supurativa foi diagnosticado à época como osteomielite aguda, talvez pelo exuberante infiltrado neutrofílico e exsudato purulento. O aspecto clínico e radiográfico de 
uma osteomielite aguda primária tem poucos sinais que justifiquem biópsias nessa fase e nem é possível localizar uma área em que isto possa ser feito. Provavelmente esta troca diagnóstica se deu pela obtenção de um fragmento em uma área de osteomielite crônica supurativa, mas sem informação na ficha de envio da presença de fistula e de um processo osteolítico evidente, permitindo ao patologista um diagnóstico compatível com a fase crônica da os te omielite supurativa.

- O fibroma ameloblástico não apresenta formação de tecido duro como o odontoma composto, uma inversão diagnóstic a observada. Há uma corrente de autores que acreditam na evolução do fibroma ameloblástico para um dentinoma, fibroodontoma ameloblástico e por fim um odontoma composto ${ }^{40}$. Outros atribuem a cada lesão uma etiopatogenia específica e não uma característica evolutiva neste processo. A troca de diagnóstico de fibroma amelobástico para odontoma composto pode ter ocorrido em função dos dentículos não terem sido incluídos para os cortes microscópicos. Na descrição macroscópica minuciosa, não presente, este dado deveria estar explicitado. Não havendo essa situação do ponto de vista microscópico, justifica-se o diagnóstico de fibroma ameloblástico, ressaltando a possível presença de áreas de fibroma ameloblástico 
num contexto de odontoma composto. Esta ocorrência reforça importância de um laudo descritivo detalhado, inclusive da fase macroscópica inter pretativa do diagnóstico anatomopatológico.

- $\mathcal{A}$ troca diagnóstica de fibroma ameloblástico para fíbroma odontogênico ocorrida em dois casos pode ser compreendida por erros de nomenclatura ou de interpretação e com base no conhecimento atual, não é justificável.

\subsubsection{Outras situações}

Algumas situações de equívocos diagnósticos ocorreram durante a elaboração do laudo e nos processos de arquivamento, pois representam trocas aparentemente absurdas do diagnóstico final e incoerente com a descrição microscópica da lâmina. Nestes casos a correção e a informação para o profissional resultarão na retificação praticamente burocrática, pois um erro tão crasso deve ter sido percebido e o diagnós tico final desconside rado pelo clínico.

Esses fatos são observados em alguns casos como o diagnóstico de cisto dentigero para uma lesão periapical, mas especificamente cisto periodontal apical constatado na figura 9D. O laudo correspondente ao caso apresentava descrição microscópica compatível com o diagnóstico de cisto periodontal apical. 
$S$ ituação similar ocorreu em dois casos, observados nas figuras $9 \mathcal{B} e$ 9D, um de granuloma periapical com diagnóstico de cisto por extravasamento mucoso e outro de cisto por extravasamento mucoso com diagnóstico de granuloma periapical. As descrições microscópicas em ambos laudos são condizentes com o diagnóstico final da lesão primária e não do diagnóstico emitido. Esses casos pertencem a profissionais distintos que provavelmente perceberam o erro diagnóstico e desconsideraram-no.

Notam-se ainda, dois casos com nítida troca de diagnósticos revelados na figura $9 \mathcal{D}$. $O$ de cisto de retenção mucosa roto para cisto periodontal apicale o de cisto periodontal apical para cisto de re tenção mucosa roto. Esses casos apresentam os laudos com descrição microscópica condizente com o diagnóstico final, porém nãa o são com as lâminas e blocos correspondentes. O laudo com diagnóstico de cisto de retenção mucosa roto possui a lâmina e bloco de um cisto periodontal apical e o de cisto periodontal apical a de cisto de retenção mucosa roto, sendo notória a troca de numeração das lâminas e blocos. A estes dados soma-se o fato de ter sido enviado pelo mesmo profissional que provavelmente observou a troca e desconsiderou os diagnósticos e mitidos.

Ocorrências como esta permite-nos duas tomadas de posição: 
a) o clínico deve checar sempre a descrição microscópica com o diagnóstico final e em casos não coerentes comunicar-se com o patologista, especialmente quando o resultado não condiz com suas observações clínic as e radiográficas;

6) o patologista deve criar mecanismos internos de checagem, pois tais equívocos podem afetar a credibilidade do seu serviço de diagnóstico. 
7 CONCLUS ÕES 


\section{CONCLUS Õ ES}

$\mathcal{N a}$ realização desse trabalto e da análise dos resultados, pude mos verificar e concluir:

1. O número de exames realizados aumentou significantemente nos últimos 37 anos de 108 em 1963, 244 em 1977, $283 \mathrm{em}$ $1980,321 \mathrm{em} 1990$ e 1314 em 2000 destacando-se o aumento ocorrido a partir de 1987. Conclui-se que a conscientização da importância dos exames anatomopatológicos e a divulgação do Serviço aumentam o número de exames enviados. O período de maior aumento se superpõe com o aumento da participação da Disciplina de Patologia em eventos científicos, orientações e publicações. Também o mesmo período se superpõe a instalação dos cursos de pós-graduação em mestrado e doutorado. Estes dois fatores contribuem com a eficiência do trinômio, conscientização, divulgação e credibilidade. 
2. Os diagnósticos emitidos devem ser rechecados de forma cíclica e atualizados, considerando as mudanças de nomenclatura condizente com o confecimento. As correções devem ser feitas sem apagar os registros anteriores, pois his toricamente reflete $m$ a evolução conce itual.

3. Existe diagnóstico que requer revisão $e$ isto indica a necessidade de intercomunicação com o patologista, bem como rechecagem diagnóstica entre os membros de um Serviço de diagnóstico anatomopatológico.

4. $\mathcal{A}$ atualização constante, o trabalho em grupo e o estimulo contínuo a análise crítica dos conceitos e critérios diagnósticos podem promover uma redução significante da falta de condizibilidade da nomenclatura e dos diagnósticos, mesmo com o passar dos anos. 
5. Mudanças comportamentais e alterações organizacionais que mudam a dinâmica da rotina diagnóstica no Serviço de Anatomia Patológica da FOB/USP aperfeiçoam o sistema implantado incluindo-se aspectos relacionados ao treinamento de recursos humanos sistematização de processos de arquivamento e informatização dos dados, laudos e outros documentos recebidos.

6. O Serviço de Anatomia Patológica da FOB/USP representa um patrimônio cultural e científico a ser preservado para realização de estudos e pesquisas pelas gerações atuais e futuras. 
REFER $\hat{E} \mathcal{N}(C I \mathcal{A S} \quad \mathcal{B} I \mathcal{B L I O G R} \mathcal{G} \mathcal{F} I C \mathcal{A S}$ 


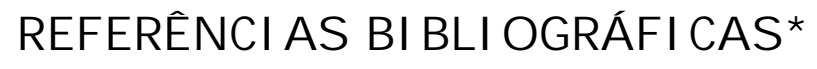

1 ACKERMANN G. L; ALTINI, M.; SHEAR $\mathcal{M}$. The unicystic ame loblas toma: a clinicopathological study of 57 cases. J. oral Pathol., v. 17, n.9/10, p.541-6, Nov. 1988.

2 ANNEROTH, G.; SIGURDSON $\mathcal{A}$. Hyperplastic lesions of the gingiva and alveolar mucosa. A study of 175 cases. Acta odontol. scand., v. 41, n. 2, p. 75.86, 1983 .

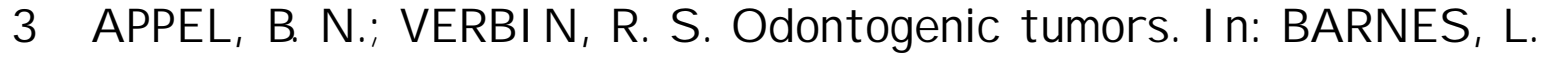
Surgical pathology of the head and neck. New York Marcel dekker, $1985 . v .2$.

4 AUCLAIR P. L.; ELLIS, G. L. Mucoepidermoid carcinoma. . In: ELLIS G.L.; AUCLAIR P. L.; GNVEPP, D.R. Surgical pathology of the salivary glands. Philadelphia, Saunders, 1991. p. 269. 97.

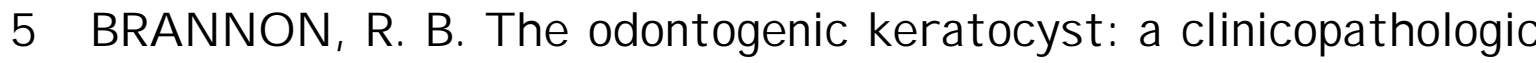
study of 312 cases, part $I$, clinical features. Oral Surg. , v. 42, n. 1, p. $54-72, \mathcal{J} u l y 1976$.

6 BRANNON R. B. The odontogenic Keratocyst: a clinicopathologic study of 312 cases, part II, histological features. Oral Surg., v. 43, n. 2, p. $233.55, \mathcal{F e} 6.1977$.

\footnotetext{
* Normas recomendadas para uso no âmbito da Universidade de São Paulo, com Gase no documento "Referências Bibliográficas: exemplos", emanado do Conselho Superior do Sistema Integrado de Bibliotecas da USP, em reunião de 20 de setembro de 1990.
} 
$7 \mathcal{B R O W}_{\mathcal{N E}}$ R. $\mathcal{M}$. The odontogenic keratocyst: clinical aspects. Brit. dent. I., v. 128, n. 5, p. 225-31, Mar. 1970.

8 BROWNE, R. M. The odontogenic keratocyst: fistological features and their correlation with clinical behaviour. Brit. dent. J., v. 131, n. 6, p. 249.59 , sept. 1971.

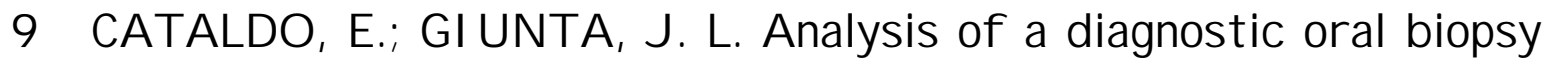
service.J. Mass. dent. Soc., v. 19, n. 4, p. $238-41, \mathcal{F a l l} 1970$.

$10 \mathcal{C H A N}$ L. R. The dentigerous cyst is a potencial adamantinoma. Dent. Cosmos, v. 75, n. 2, p.889.93, guly 1933.

11 CONSOLARO, A. Caracterização microscopia de folículos pericoronários de dentes não irrompidos e parcialmente irrompidos, sua relação com a idade. Bauru, 1987. 257 . Tese (Doutorado) - Faculdade de Odontologia de Bauru, Universidade de $S$ ão Paulo.

12 CONSOLARO, A. et al. Carcinoma mucoepidermóide intra-ósseo: revisão e relato de um caso. Rev. Centro de Cien. Biomed. Univ. Fed. Ube rlândia., v. 1, n. 1, p. 33 -41, de z. 1985.

13 CONSOLARO, A.; RIBEIRO, F.C. Pe riapicopatias: e tiopatogenia e inter-relações dos aspectos clínicos, radiográficos e microscópicos e suas implicações terapêticas. In: LEONARDO, $\mathcal{M}$. R.; LEAL, J.M. Tratamento de canais radiculares.3.ed.S ão Paulo, Panamericana, 1998.p. $77-102$. 
$14 \mathcal{D A} \mathcal{M} \mathcal{A} \mathcal{N} \mathcal{T}$, g. H. Estudo dos folículos pericoronários de dentes não irrompidos e parcialmente irrompidos. Inter-relação clínica, radiográfica e microscópica. Bauru, 1987.245 p. Tese (Livre Docência) - Faculdade de Odontologia de Bauru, Universidade de $S$ ão Paulo.

15 ELLIS, G. E.; AUCLAIR P. L. Clear cell carcinoma. . In: ELLIS G. L.; AUCLAIR P. L.; GNEPP, D. R. Surgical pathology of the salivary glands. Philadelphia, Saunders, 1991.p.379-89.

$16 \mathcal{F E C H \mathcal { N } R}$ R. $\mathcal{E}$. Necrotizing sialometaplasia. $\mathcal{A}$ source of confusion with carcinoma of the palate. Amer. J. clin. Path., v. 67, n. 4, p. $315-7, \mathcal{A p r} .1977$.

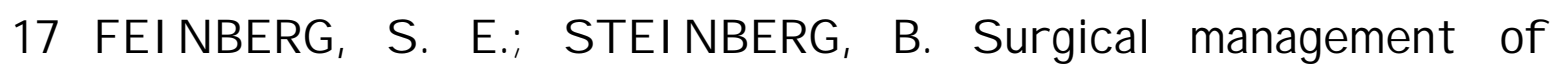
ameloblastoma current status of the literature. Oral Surg., v. 81, n. 4, p. $383-8, \mathcal{A p r} .1996$.

$18 G \mathcal{G} \mathcal{R D N E R} \mathcal{D}$. G. A pathologist's approach to the treatment of ame loblastoma. I. oral Maxillofac. Surg., v. 42, n. 3, p. 161 6, Mar. 1984 .

$19 G \mathcal{A R D}(\mathcal{E R}, \mathcal{D}$. G. Plexiform unicystic ameloblastoma: a diagnostic problem in dentigerous cysts. Cancer, v. 47, n. 15, p. 1358-63, Mar. 1981.

20 GARDNER $\mathcal{D}$. G. The treatment of ameloblastoma based on pathologic and anatomic principles. Cancer, v. 46, n. 11, p. $2514-9$, Dec. 1980 . 
21 GARLOCK g. A.; PRIN $\mathcal{N G E , ~ G . ~ A . ; ~ H I C K S , ~ M . ~ L . ~ T h e ~ o d o n t o g e n i c ~}$ Keratocyst: a potential endodontic misdiagnosis. Oral $\mathcal{S} u r g ., v$. 85, n. 4, p. $452-6, \mathcal{A p r} .1998$.

22 GENERS ON R. M.; PORTER I. M.; STRATIGOS, G. T. Mural odontogenic epithelial proliferations within the wall of a dentigerous cyst: their significance. Oral Surg., v. 42, n. 4, p. 717 - 21, Dec. 1976.

23 GORLIN R. I. Potentialities of oral epithelium manifest by mandibular dentigerous cysts. Oral Path., v. 10, n. 3, p. 271 84, Mar. 1957.

24 GRILLON G. L.; LALLY, $\mathcal{E}$. T. Necrotizing sialome taplasia: literature review and presentation of five cases. I. oral surg., v. 39, n. 10, p. 747.53, Oct. 1981.

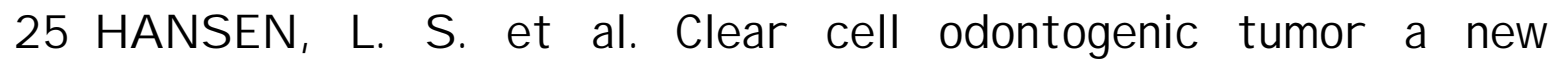
histologic variant with aggressive potential. Head $\mathcal{N e c k} S$ urg. v. 8, n. 2, p. $115-23, \mathcal{N o v . / D e c . ~} 1985$.

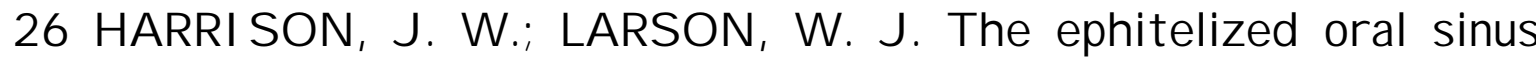
tract. Oral Surg., v. 42, n. 4, p. 511-7, Oct. 1976.

27 HUVOS, A. G. Bones Tumores: diagnosis, treatment and prognosis 2.ed. Pfiladelphia, Saunders, 1991.

28 I ENS EN I. L. Idiopatic diseases. . In: ELLIS G. L; AUCLAIR P. L.; GNEPP, D. R. Surgical pathology of the salivary glands. Philadelphia, S aunders, $1991 . p .60-82$. 
29 I OS ELL, S. D.; REIS KI N A. B.; GROSS, B. D. Dentigerous cyst with mural ameloblastoma. I. Amer. dent. ass., v. 99, n. 4, p.634-6, oct. 1979 .

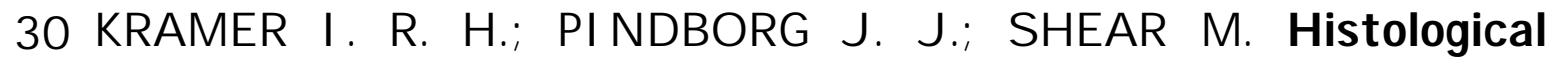
typping of odontogenic tumors. 2. ed. Berlin, S pringer-Verlag, 1992.

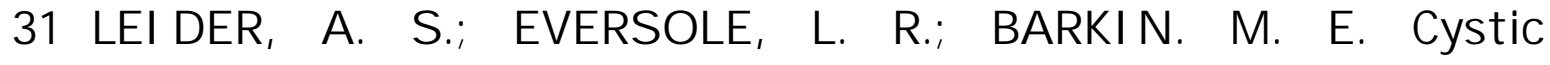
ame loblas toma: a clinicopathologic analys is. Oral $S$ urg., v. 60, n. 6, p. 624-30, Dec. 1985 .

$32 \mathscr{M C B R O O M} \mathcal{H} . \mathcal{M}$; $\mathcal{R A M S} \mathcal{A Y}, \mathcal{A}$. D. The clinic o pathologic al me e ting. $\mathcal{A}$ means of auditing diagnostic performance. Amer. I. Surg. Path., v. 17, n. 1, p. $75-80$, gan. 1993.

$33 \mathcal{M C M I} \mathcal{L} \mathcal{A} \mathcal{N}$ M. D.; $S \mathcal{M I L L I E , ~} \mathcal{A}$. C. Ameloblastomas associated with dentigerous cysts. Oral Surg., v. 51, n. 5, p. 489-96, May 1981.

34 ODELL, E. W.; MORGAX P. R. Biopsy pathology of the oral tissues. London, Chapman \& Hall Medical, 1998.

35 OEHLERS, F. A. C. Periapical lesions and residual dental cysts. Brit. J. oral Surg., v.8, n. 2, p. 103-13, №v. 1970.

36 ORGAN G.; $\mathcal{M A I N}$ I. H. P. Ultilization of an oral pathology diagnostic service by dentists. I. Canad. dent. ass., v. 42, n. 11, p. $555-8, \mathcal{N o v} .1976$. 
37 PAGE, R. C.; SCHROEDER, H. E. Pathogenesis of inflamatory periodontal disease: a summary of current work. Lab. Invest., v. 34, n. 3, p. 235.49, Mar. 1976.

38 PAUL, I. K; FAY, g. T.; STAMPS, P. Recurrent dentigerous cyst evidencing ameloblastic proliferation: report of case. I. oral Surg., v. 27, n. 3, p. 211-4, Mar. 1969.

$39 \mathcal{P H I L I P S} \mathcal{E N} \mathcal{H}$. P.; REICHART P. A. Unicystic ameloblas toma. a review of 193 cases from the literature. Oral Oncol., v. 34, $\mathrm{n}$. 5, p. $317-25$, sept. 1998 .

40 PHI LIPS EN; $\mathcal{H}$. P.; REICHART, P. A.; PRAETORIUS A. Mixed odontogenic tumours and odontomas. Considerations on interrelationship. Review of the literature and presentation of 134 newcases of odontomas. Oral Oncol., v. 33, n.2, p.86-99, Mar. 1997.

41 PINDBORG, J. J. et al. Histological typing of cancer and precancer of the oral mucosa. 2.ed. Springer, Berlin, 1997.

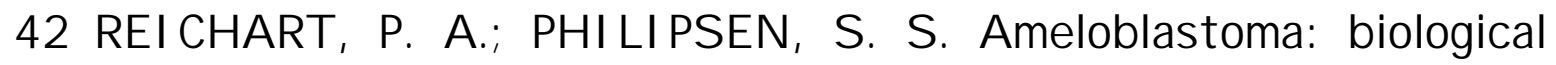
profile of 3677 cases. Oral Oncol, Eur. J. Cancer, v. $31 \mathcal{B}$, n.2, p.86-99, Mar. 1995.

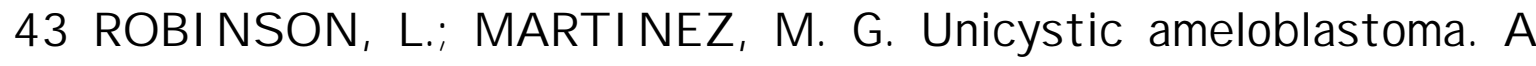
prognostically distinct entity. Cancer, v. 40, n. 5, p. 2278-85, ov. 1977. 
$44 \mathcal{S} \mathcal{H} \mathcal{A} \mathcal{F} \mathcal{R}, G . \mathcal{N}$; $\mathcal{H} I \mathcal{N E}$ K. $\mathcal{M}$; LEV $\mathcal{L} \mathcal{M}$. B. Patologia bucal. 3. ed., Rio de ganeiro, Interamericana, 1979.

$45 \mathcal{S H E A R} \mathcal{M}$. Cistos da região bucomaxilofacial: diagnóstico e tratamento.3.ed. São Paulo, Ed. Santos, 1999.

46 SIAR H. C.; $\mathcal{T A N}$ B.H. Oral biopsy turnround time: 20 -year experience of the Department of Oral Pathology, Oral Medicine and periodontology, Faculty of Dentistry, University of Malaya. I. Oral Sci., v. 42, n. 4, p. 205-10, Dec. 2000.

$47 S \mathcal{L A B B E R T}, \mathcal{H}$; $S \mathcal{H E A R} \quad \mathcal{M}$; $\mathcal{A} \mathcal{L} \mathcal{T} I N, \mathcal{M}$. Vacuolated cells and mucous metaplasia in the epithelial linings of radicular and residualcysts. I. oral Path. Med. v. 24, n. 7, p.309-12, Aug. 1995.

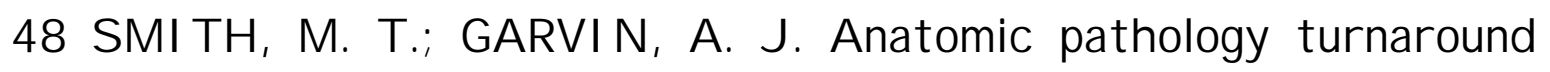
times: use and abuse. Am. J. Clin. Pathol., v. 106, S70-S73, 1996. Suppl. 1.

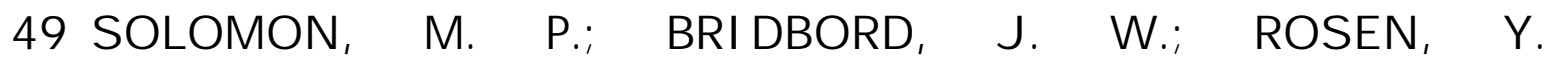
Pseudoameloblastomatous changes in the wall of a radicular cyst. Amer. J. clin. Path., v. 61, n. 3, p. 443-7, Mar. 1974.

$50 S P E T I C, \mathcal{M}$. B. S. A. Avaliação da presença de mastócitos e m hemangiomas e granulomas piogênicos bucais. Bauru, 2001. 121 p. Dissertação (Mestrado) - Faculdade de Odontologia de Bauru, Universidade de $S$ ão Paulo.

51 SPOUGE, g. D. Oral pathology. St Louis, Mosby Company, 1973. 
52 UENO, S ; SHIRASUl, R. Prognostic evaluation of ame loblas toma based on fistologic and radiographic typing. I. oral Maxillofac. Surg.,v. 47, n. 1, p. 11-5, g an. 1989.

$53 \mathcal{V} \hat{E} \mathcal{N} C I O, \mathcal{E}$. F. Estudo morfológico comparativo entre o ameloblastoma e o carcinoma basocelular na microscopia óptica. Bauru, 1995. 78 p. Dissertação (Mestrado)-Faculdade de Odontologia de Bauru, Universidade de $S$ ão Paulo.

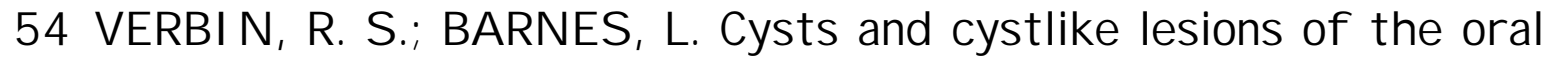
cavity, jaws, and neck. In: BARNES, L. Surgical pathology of the head and neck. New York Marcel dekker,1985. v.2, p.1233-9.

55 VICKERS, R. A.; GORSIN R. I. Ameloblastoma: delineation of early histopathologic features of neoplasia. Cancer, v.26, n.3, p.699- 710 , sept. 1970 .

$56 \mathcal{W} I \mathcal{L L A M S}, \mathcal{H}$. I ; HEY, A. A.; BROW'NE, R.M. The use by general dental practitioners of an oral pathology diagnostic service over a 20 -year period: the Birmingham Dental Hospital experience. Brit. dent. I., v. 182, n. 11, p. 424-9, I une 1997.

$57 \mathcal{W} I \mathcal{L L I} \mathcal{A M S}, \mathcal{T}$. P. Management of ameloblastoma; a changing perspective. I. oral Maxillofac. Surg., v. 51, n. 10, p. 1064 $70, O c t .1993$.

$58 \mathcal{Y A A C O B , ~} \mathcal{H}$. B.; $\mathcal{L} \mathcal{N} \mathcal{N}, \mathcal{K} . \mathcal{C}$. Ameloblastomatous changes in dentigerous cysts. Aust dent. J., v. 27, n. 6, p. 365-7, Dec. 1982 . 
ABS TRACT 
$\mathcal{A B S} \mathcal{T} R \mathcal{A C T}$

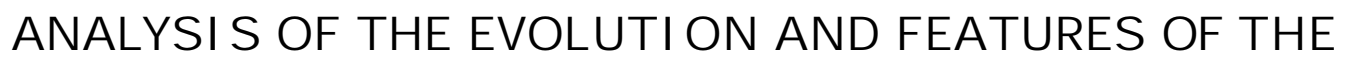
$\mathcal{A N} \mathcal{A} \mathcal{T} O \mathcal{M Y}$ ORAL $\mathcal{P A T H O L O} G \mathcal{Y} S \mathcal{E R V I C E}$

FOR THIRTY S EVEX YEARS

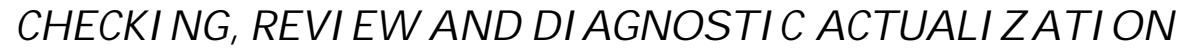

Analysis of archives of the Anatomy Pathology Service of Bauru Dental School, São Paulo University, since 1963-2000 to study the evolution and characteristics, promoting a re-examination and actualization of their archives and methods. It was observed a significative increment of demand in the lending Services, and an improvement of these. It was made a revision of the report copies, 6locks fistologic and slides, evaluating the nomenclature of the lesions according to the nowadays; identification of new clinical entities and diagnostic errors. It was discuss the provable reasons of the found differences and conclude the necessity of a continue actualization in the work of group, and the constant incentivation to critical analysis of concepts and diagnostic criteria on every moment of practice in the oral pathology as a dental speciality. 